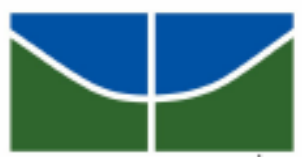

UNIVERSIDADE DE BRASÍLIA

Centro de Excelência em Turismo

Pós-graduação lato sensu

Curso de Especialização em Turismo e Desenvolvimento Econômico

\title{
AS AÇÕES DO PRODETUR/ NE E SUAS IMPLICAÇÕES PARA O DESENVOLVIMENTO DO TURISMO NA PARAÍBA
}

Anna Karenina Chaves Delgado

Orientador: Jorge Madeira Nogueira

Brasília - 2008 


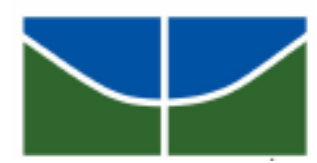

UNIVERSIDADE DE BRASÍLIA

Centro de Excelência em Turismo

Pós-graduação lato sensu

Curso de Especialização em Turismo e Desenvolvimento Econômico

\title{
AS AÇÕES DO PRODETUR/ NE E SUAS IMPLICAÇÕES PARA O DESENVOLVIMENTO DO TURISMO NA PARAÍBA
}

\author{
Anna Karenina Chaves Delgado \\ Orientador: Jorge Madeira Nogueira
}

Monografia apresentado ao Centro de Excelência em Turismo - CET, da Universidade de Brasília - UnB, como requisito parcial à obtenção do grau de especialista em turismo e desenvolvimento econômico. 
Delgado, Anna Karenina.

As ações do PRODETUR/ NE e suas implicações para o desenvolvimento do turismo na Paraíba./ Delgado, Anna Karenina Brasília, 2008.

338.482.2:330

Monografia (especialização) - Universidade de Brasília, Centro de Excelência em Turismo, 2008.

Orientador: Jorge Madeira Nogueira

1. PRODETUR. 2. Desenvolvimento econômico. 3. Políticas públicas de turismo. As ações do PRODETUR/ NE e suas implicações para o desenvolvimento do turismo na Paraíba. 


\section{UNIVERSIDADE DE BRASÍLIA}

Centro de Excelência em Turismo

Pós-graduação Lato Sensu

Curso de Especialização em Turismo e Desenvolvimento Econômico

Monografia apresentada ao Centro de Excelência em Turismo - CET, da Universidade de Brasília - UnB, como requisito parcial à obtenção do grau de Especialista em Turismo e Desenvolvimento Econômico.

\section{As ações do PRODETUR/ NE e suas implicações para o desenvolvimento do turismo na Paraíba}

Anna Karenina Chaves Delgado

Aprovado por

Prof. PHD Jorge Madeira Nogueira

Professor Examinador

Brasília, 24 de março de 2008. 


\section{DEDICATÓRIA}

A minha mãe Maria Célia, pela incansável dedicação e por sempre acreditar no meu potencial. Aos Avós, José Chaves (in memória) $e$

Maria do Carmo. Aos Irmãos, Vladimir e Anna Karina. Aos meus verdadeiros amigos pelo apoio e carinho constantes, em especial a Heloísa, Luciana, Danielle e Jeice. Aos meus colegas de pós-graduação do curso de turismo e desenvolvimento econômico da Universidade de Brasília. Aos colegas e professores da graduação do curso de turismo da Universidade Federal da Paraíba pelo aprendizado e crescimento. 


\section{AGRADECIMENTOS}

Meus agradecimentos e minha gratidão,

Ao professor Jorge Madeira Nogueira pelo interesse, orientação e ensinamentos ministrados antes e durante o período de desenvolvimento da monografia.

A professora Maria de Lourdes R. Mollo (Lourdinha) pelos ensinamentos ministrados em sala de aula.

A ex-orientadora de graduação e assistente técnica do PRODETUR/PB, Joelma Abrantes Guedes pelas informações passadas sobre o programa.

Aos colegas de curso pelos debates sempre pertinentes em sala de aula 
Somos a porta do Sol

Deste país tropical Somos a mata verde, a esperança Somos o Sol do extremo oriental A Lua fez um poema, nas palhas do coqueral Eu escrevi seu nome na areia No coração do extremo oriental A lua do interior Brilhou lá na capital E clareou o céu da Borborema No Cariri no extremo oriental Salve o Sertão, o Brejo, a Borborema Que vem saldar o extremo oriental. O calor do verão chegou pra te abraçar essa alegria é beira de mar Compositor: Flávio Eduardo - Mestre Fubá (1996) 


\section{RESUMO}

O estudo analisa as ações do PRODETUR no Estado da Paraíba. Para tanto, foram levantadas, através dos relatórios do Banco do Nordeste e do Tribunal de Contas da União, todas as ações realizadas pelo programa em sua primeira fase, também foi estabelecido contato com a coordenadora do PRODETUR/ PB com o intuito de saber se o programa já havia efetuado alguma ação em sua segunda fase na Paraíba. Foram obtidas informações que permitiram analisar as reais intenções do programa, assim como de que modo o programa pretende auxiliar no desenvolvimento turístico do estado em questão realizando inclusive comparação entre os investimentos destinados a Paraíba e aos outros estados beneficiados. Verificou-se que, apesar do programa possuir um discurso de inclusão e favorecimento da população mais pobre, atua mais como um concentrador de investimentos nas regiões nordestinas mais desenvolvidas turística e economicamente. Destaca-se também a razão da necessidade de intervenção do Estado no mercado, assim como os principais instrumentos utilizados pelo Governo para intervir no mercado turístico e questionasse o turismo como instrumento de desenvolvimento.

PALAVRAS-CHAVE: PRODETUR, desenvolvimento econômico, políticas públicas de turismo. 


\section{ABSTRACT}

This study examines the actions of PRODETUR in the state of Paraíba. For this purpose information was collected in reports of Banco do Nordeste and Tribunal de Contas da União, dealing with actions by the program in its first phase. It was also established contact with the coordinator of PRODETUR / PB to understand the actions of this program in the second phase. Information was collected which allowed us to analyze the real intentions of the program, and how the program is intended to assist in the development of tourism in the state of Paraíba performing also comparison of investments to Paraíba and other states benefited. It was found that although the program has a speech of inclusion and favors the poor, serves as a tool for investments in more developed parts of the Northwest. We also discuss the reason for the need of state interference in the market, as the main instruments used by the government to interfere in the tourist market and questioned tourism as a tool for development.

KEY WORDS: PRODETUR, economic development public policy of tourism. 


\section{LISTA DE FIGURAS}

Figura 01: Fluxo circular de renda e dos gastos .................................................................. 19

Figura 02: Sistema de Turismo (SISTUR) ..................................................................... 35

Figura 03: Subsistema da infra-estrutura do SISTUR ...................................................... 37

Figura 04: Vista aérea do final do bairro do Cabo Branco ...................................................... 46

Figura 05: Pólos de turismo - PRODETUR fase II ............................................................ 48

Figura 06: Mapa das microrregiões do sertão ......................................................................... 54

Figura 07: Mapa das microrregiões da borborema .......................................................... 55

Figura 08: Mapa das microrregiões do agreste ............................................................... 56

Figura 09: Mapa das microrregiões da zona da mata .......................................................... 57

Figura 10: A Cruz da Menina - Patos/ PB ..................................................................... 60

Figura 11: Vale dos Dinossauros - Sousa/ PB ............................................................. 61

Figura 12: Estância Termal Brejo das Freiras ...................................................................... 61

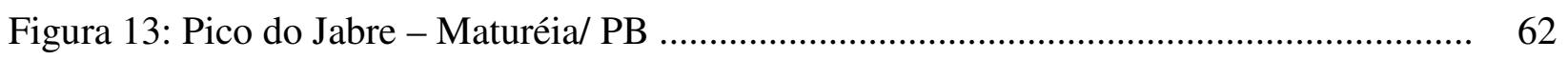

Figura 14: Lajedo do Pai Mateus - Cabaceiras/ PB ............................................................. 63

Figura 15: Memorial de Frei Damião - Guarabira/ PB ..................................................... 63

Figura 16: Cachoeira do Roncador - divisa entre Pirpirituba/ PB e

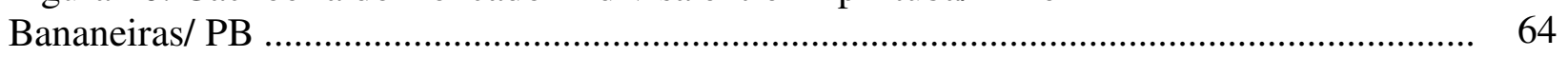

Figura 17: Festa de São João - Campina Grande/ PB ............................................................... 64

Figura 18: Pedra da Boca - Araruna/ PB ..................................................................... 65

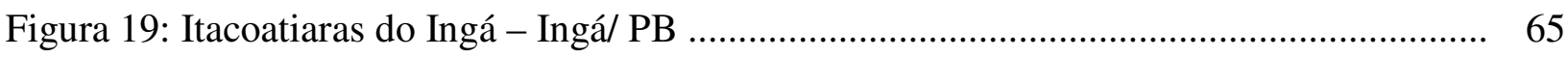

Figura 20: Pôr-do-sol na Praia do Jacaré - Cabedelo/ PB .................................................... 66

Figura 21: Casa da Pólvora - João Pessoa/ PB ................................................................. 67

Figura 22: Igreja de Nossa Senhora da Guia - Lucena/ PB ................................................. 68

Figura 23: Bloco das Muriçocas do Miramar (Folia de Rua) - João Pessoa/ PB ................... 68

Figura 24: Mapa do potencial turístico da Paraíba ................................................................ 72

Figura 25: Praça Antenor Navarro - Centro Histórico de João Pessoa/ PB ............................ 95 


\section{LISTA DE GRÁFICOS}

Gráfico 01: Faixa etária da população paraibana - 2005

Gráfico 02: Taxa de escolarização da população paraibana segundo

faixa etária - 2005

Gráfico 03: Desemprego na Paraíba

Gráfico 04: Recursos aplicados nos estados nordestinos 


\section{LISTA DE QUADROS}

Quadro 01: Componentes diretos do produto turístico 34

Quadro 02: Períodos e ações governamentais em prol do turismo 41

Quadro 03: Quadro comparativo do Índice de Gini 53

Quadro 04: Alguns indicadores do sertão paraibano x Brasil 54

Quadro 05: Alguns indicadores da borborema paraibana x Brasil 55

Quadro 06: Alguns indicadores do agreste paraibano x Brasil ........................... 56

Quadro 07: Alguns indicadores da zona da mata paraibana x Brasil ................... 57

Quadro 08: Pólos criados pelo Plano Amanhecer 71

Quadro 09: Movimento de passageiros em vôos nacionais nos aeroportos da Paraíba

Quadro 10: Movimentação interestadual de passageiros nas rodoviárias das principais capitais nordestinas

Quadro 11: Indicadores do turismo na Paraíba 1996/2004 _................................. 75

Quadro 12: Ações de infra-estrutura do PRODETUR/NE I ................................. 77

Quadro 13: Ações do PRODETUR em Desenvolvimento Institucional na Paraíba

Quadro 14: Infra-estrutura Básica Urbana (Saneamento e Esgoto)

Quadro 15: Recursos Investidos em Rodovias na Paraíba pelo 
LISTA DE TABELAS

Tabela 01: Maiores receptores de turistas

Tabela 02: Mercado do turismo no Brasil por região

Tabela 03: Serviços básicos de infra-estrutura 50

Tabela 04: Extensão territorial do litoral x investimentos do PRODETUR/ NE I 82 


\section{LISTA DE SIGLAS}

Banco Interamericano de Desenvolvimento

BID

Banco Mundial

BIRD

Banco Nacional do Nordeste

$\mathrm{BNB}$

Coeficiente de Atração Turística

CAT

Comissão Brasileira de Turismo

COMBRATUR

Companhia de Água e Esgotos da Paraíba

CAGEPA

Conjunto da Organização Estrutural

$\mathrm{OE}$

Conjunto das Ações Operacionais

$\mathrm{AO}$

Conjunto das Relações Ambientais

RA

Conselho Nacional de Turismo

CNTUR

Departamento de Estradas e Rodagem da Paraíba

$\mathrm{DER} / \mathrm{PB}$

Instituto Brasileiro de Turismo

EMBRATUR

Empresa Paraibana de Turismo

PBTUR

Fundo de Investimento da Amazônia

FINAM

Fundo de Investimento do Nordeste

FINOR

Fundo de Investimento Setorial

FISET

Fundo Geral do Turismo

FUNGETUR

Instituto Brasileiro de Geografia e Estatística

IBGE

Índice de Desenvolvimento Humano

IDH

Instituto de Patrimônio Histórico do Estado da Paraíba

IPHAEP

Instituto do Patrimônio Histórico e Artístico Nacional

IPHAN

Mercado de Artesanato da Paraíba

MAP

Ministério do Turismo

MTUR

Organisation de Coopération et Développement Économique

OCDE 
Organização Mundial do Turismo

OMT

Organização não Governamental

ONG

Pesquisa Nacional por Amostragem de Domicílio

PNAD

Plano Nacional de Turismo

PLANTUR

Produto Interno Bruto

PIB

Programa das Nações Unidas para o Desenvolvimento

PNUD

Programa de Ação para o Desenvolvimento do Turismo no Nordeste

PRODETUR/ NE

Programa de Ação para o Desenvolvimento do Turismo na Paraíba

PRODETUR/ PB

Programa de Desenvolvimento do Turismo Sustentável

PDTIS

Programa Nacional de Municipalização do Turismo

PNMT

Programa Nacional de Regionalização do Turismo

PRT

Programa para o Desenvolvimento do Turismo na Amazônia Legal

PROECOTUR

Secretaria de Turismo do Município de João Pessoa

SETUR/ JP

Serviço Brasileiro de Apoio às Micro e Pequenas Empresas

SEBRAE

Serviço Nacional de Aprendizagem Comercial

SENAC

Superintendência de Administração do Meio Ambiente

SUDEMA

Superintendência de Desenvolvimento do Nordeste

SUDENE

Sistema Nacional do Meio Ambiente

SINAMA

Sistema de Turismo

SISTUR

Tribunal de Contas da União

TCU

Unidade Executora do Estado

UEE

Unidade Habitacional

$\mathrm{UH}$

Unidade de Conservação

UC 


\section{SUMÁRIO}

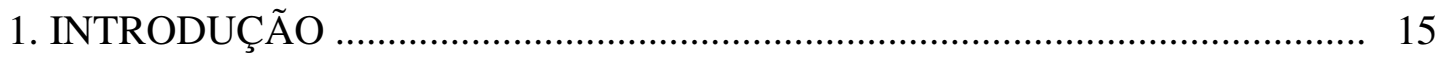

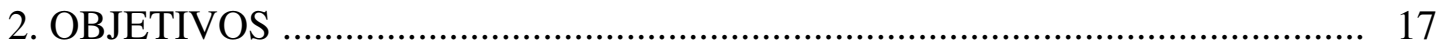

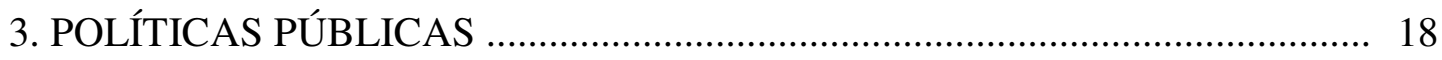

3.1 - Os economistas em discordância ....................................................... 18

3.2 - As falhas de mercado ....................................................................... 22

3.3 - O turismo como instrumento de desenvolvimento …............................. 25

4. INFRA-ESTRUTURA E TURISMO _..................................................... 31

4.1 - Componentes do turismo ................................................. 31

4.2 - Intervenção estatal, desenvolvimento regional e políticas públicas de

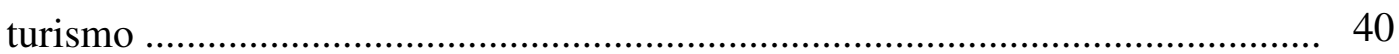

4.3 - PRODETUR/ NE ................................................................. 45

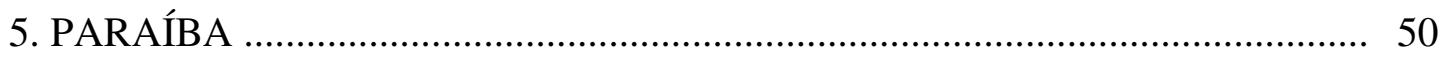

5.1 - Informações Gerais ........................................................................ 50

5.2 - Turismo na Paraíba .......................................................................... 58

6. APRESENTAÇÃO E ANÁLISE DOS RESULTADOS DA PESQUISA ......... 76

6.1 - Funcionamento do PRODETUR/ NE ................................................... 76

6.2 - Apresentação das Ações do PRODETUR/ PB .......................................... 84

6.3 - Análise dos Resultados Apresentados ..................................................... 90

7. CONSIDERAÇÕES FINAIS _................................................................. 100

8. REFERÊNCIAS BIBLIOGRÁFICAS ..................................................... 103

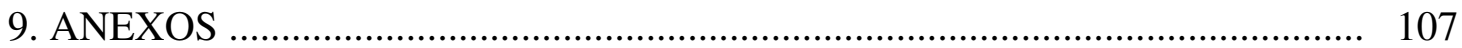




\section{INTRODUÇÃO}

As diferentes linhas de pensamento econômico enxergam a atuação estatal de diferentes formas. Para os neoclássicos o mercado, apesar de gerar falhas transitórias, representa o melhor mecanismo regulador. Esta visão está baseada na percepção que os neoclássicos têm sobre o funcionamento da taxa de juros como variável reguladora dos investimentos e dos vazamentos, fazendo com que eles se igualem. Por outro lado, os keynesianos acreditam num Estado atuante, que busque soluções para as falhas de mercado, que segundo esta visão não são transitórias. A economia é permeada por incertezas e a relação poupança/ investimentos também é influenciada por estas incertezas. Já os marxistas, acreditam que a intervenção estatal é imprescindível, não representando, no entanto, a solução para os problemas gerados pelo mercado, já que a origem destes problemas é a lógica capitalista. Apesar das diversas teorias econômicas observarem a intervenção do Estado na economia como potencialmente danosa ou benéfica, uma coisa é certa, o mercado apresenta falhas, e o argumento utilizado pelas correntes econômicas que acreditam na atuação do Estado na economia é que o Estado pode buscar soluções, transitórias ou não, para as falhas de mercado, através das políticas públicas.

Deste modo, a intervenção estatal também pode ser notada na atividade turística. O primeiro órgão que representou um marco na atuação federal do turismo foi o Instituto Brasileiro de Turismo (EMBRATUR), que já em seus primeiros anos de funcionamento incentivou o planejamento e a implementação da política pública dos megaprojetos no Nordeste. O primeiro deles, o Parque das Dunas Via Costeira foi criado pelo Governo Estadual do Rio Grande do Norte no final da década de 1970, seguindo-se a este foram criados: Projeto Cabo Branco em João Pessoa - PB (na década de 1980), Projeto Costa Dourada em Pernambuco e Alagoas (na década de 1990) e Projeto Linha Verde no litoral da Bahia (década de 1990).

O surgimento no Brasil do modelo de desenvolvimento do turismo baseado nos megaempreendimentos hoteleiros, já adotados em Cancun, fez emergir a necessidade de um instrumento que dotasse os núcleos receptores de infra-estrutura para que os investidores, em especial os estrangeiros, efetivassem de fato seus investimentos nas cidades do litoral nordestino. Com o intuito de atrair estes investimentos estrangeiros e 'promover o desenvolvimento do turismo' é criado o Programa de Ação para o Desenvolvimento do Turismo no Nordeste (PRODETUR/ NE) em 1992. 
Apesar do programa afirmar que beneficiaria prioritariamente a população mais carente das localidades turísticas observamos que grande parte de seus recursos foram destinados aos estados nordestinos mais desenvolvidos, a exemplo da Bahia e do Ceará.

O PRODETUR/ NE atuou, em sua primeira fase, nos nove estados nordestinos a partir de investimentos, vindos do Banco Interamericano de Desenvolvimento (BID), nos setores de desenvolvimento institucional, infra-estrutura e estudos/ projetos. $\mathrm{Na}$ Paraíba os investimentos vindos do BID de maior destaque foram aqueles referentes à construção de infra-estrutura no quesito saneamento básico, em especial, na construção de redes coletoras de esgoto.

A principal fonte de pesquisa deste trabalho é constituída pelos relatórios do Banco do Nordeste apresentando as ações efetuadas pelo PRODETUR em todos os estados nordestinos em sua primeira fase, estes estão disponíveis no site do Banco do Nordeste (www.bnb.gov.br). Também foram amplamente utilizados os relatórios do Tribunal de Contas da União com uma avaliação do PRODETUR/ NE, estes, assim como os anteriores, se encontram disponíveis para download no site do Banco do Nordeste. As outras fontes utilizadas na pesquisa foram: a observação in loco de algumas localidades da Paraíba contempladas com verbas do PRODETUR, esta observação foi realizada em dezembro de 2007 e o registro fotográfico.

Este trabalho se encontra estruturado da seguinte forma. O primeiro capítulo fala sobre as divergentes visões com relação à intervenção do Estado e as falhas que o mercado apresenta. O primeiro capítulo também traz uma reflexão sobre a adoção do turismo como instrumento de desenvolvimento e as formas utilizadas pelo Estado para intervir no planejamento turístico no Brasil. O segundo capítulo apresenta o histórico do turismo assim como a importância da infra-estrutura para o funcionamento do Sistema de Turismo (SISTUR) e o Programa de Desenvolvimento do Turismo do Nordeste (PRODETUR/ NE). Explicando a real intenção deste programa quando foi criado, sua área de atuação e seu funcionamento. O terceiro capítulo apresenta algumas informações gerais, no que se refere aos indicadores econômicos e sociais, da Paraíba. Também evidência a história do turismo na Paraíba, seus principais atrativos, suas políticas públicas e seus indicadores no que se refere aos fluxos turísticos/ receitas/ gastos. O quarto capítulo apresenta as ações do PRODETUR na Paraíba, tecendo comentários sobre estas. O quinto capítulo conclui a monografia com considerações sobre o programa em sua primeira fase. 


\section{OBJETIVOS}

\section{1 - OBJETIVO GERAL}

Avaliar o impacto PRODETUR/ NE, Fase I, na concentração/ desconcentração da atividade econômica do turismo e sua relevância enquanto gerador de emprego e renda para o Estado da Paraíba.

\section{2 - OBJETIVOS ESPECÍfICOS}

1. Discutir a elaboração das políticas públicas;

2. Analisar a atividade turística como vetor de desenvolvimento;

3. Pesquisar as potencialidades turísticas do Estado da Paraíba;

4. Explicar o funcionamento e as origens do PRODETUR/ PB;

5. Investigar as ações efetivadas pelo PRODETUR/ PB e refletir acerca da importância destas ações para o desenvolvimento do turismo na Paraíba. 


\section{POLÍTICAS PÚBLICAS}

\section{1 - Os Economistas em Discordância}

As políticas públicas correspondem ao mecanismo de atuação do Governo frente a uma realidade que por algum motivo não funciona eficientemente. Deste modo cabe traçarmos algumas considerações a este respeito. A primeira questão levantada ao mencionar a criação de políticas públicas é o seu caráter contraditório com relação as diferentes teorias econômicas. A sua eficácia é amplamente questionada pelas distintas correntes econômicas que possuem idéias incongruentes entre si.

Muitos economistas formados na tradição da teoria neoclássica acreditam que a intervenção do Estado na economia é danosa, constituindo em um fator perturbador do equilíbrio gerado pelo mercado em longo prazo. A atuação do Estado, por meio de políticas públicas, segundo os neoclássicos, deve se restringir ao controle da ordem, com políticas que assegurem, por exemplo, a propriedade privada. A atuação do Estado na economia, por intermédio de, por exemplo, uma política de controle cambial ou de importações-exportações, é sempre observada como ineficiente. Esta afirmação fica clara na colocação de Carvalho (1999, p.12), onde ele assegura que os neoclássicos acreditam que:

[...] as sociedades organizam sua vida econômica de modo mais eficiente se livres da interferência de poderes estranhos aos interesses dos próprios indivíduos. A sociedade se ordena de forma espontânea para satisfazer estes interesses, sendo desnecessárias quaisquer medições que não aquelas estabelecidas no próprio mercado, onde cada um joga com seu interesse próprio e, nesse jogo, como orientada por uma 'mão invisível' (Smith), a economia se organiza. Definindo o Estado como prejudicial, a ordem econômica passa a assentar-se sobre o interesse privado, livremente manifestado no mercado.

A principal razão para que os neoclássicos pensem deste modo consiste na visão que eles têm sobre o processo de produção de um determinado país. Para esta corrente os vazamentos são compensados pelos investimentos e deste modo a economia se autoregula através do mercado. O sistema funciona de modo a não necessitar de intervenção alguma, sob pena de quebrar o fluxo e assim gerar ineficiências. Para entendermos melhor o processo produtivo devemos observar a figura da página seguinte: 
Figura 01: Fluxo Circular de Renda e dos Gastos

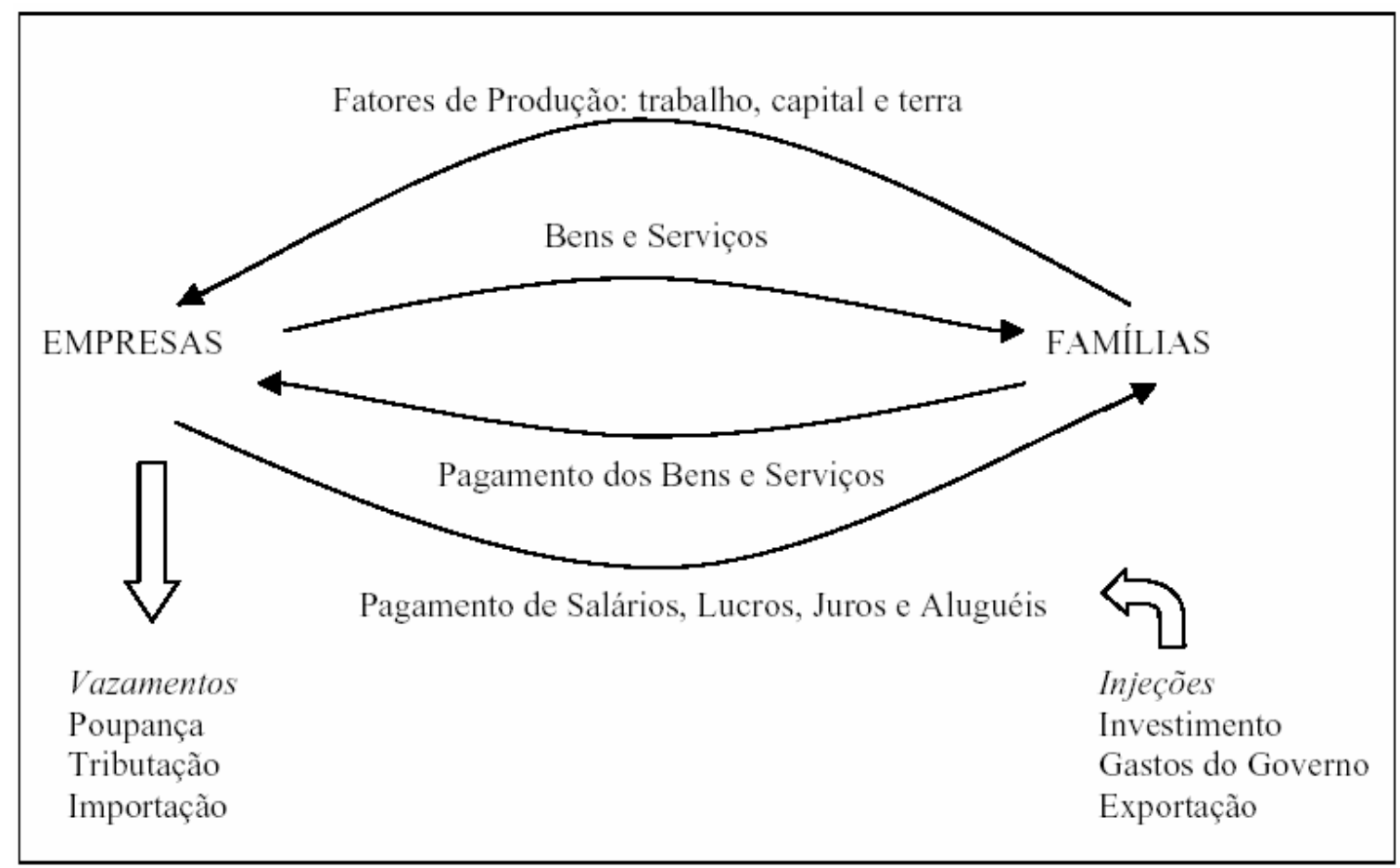

Fonte: Amado e Mollo (2003, p.03).

A divergência entre os neoclássicos e os keynesianos, com relação a Figura 01, remete ao fato de que os primeiros acreditam que a poupança (vazamento) tende a ser sempre coberta pelos investimentos (injeções). Para eles, os investimentos e a poupança são determinados pela 'taxa de juros'. O funcionamento desta variável, sua alta ou queda, é proporcional ao desejo de poupar. Quanto maior a taxa de juros mais pessoas desejarão poupar, já com relação aos investimentos, a variável ('taxa de juros') é inversamente proporcional. Quanto menor a taxa de juros maior o desejo por parte dos empresários de tomar empréstimos para investir.

Por existir esta inversa proporcionalidade entre a quantidade de poupança e de investimentos, em decorrência dos juros, este último tenderá a um ponto de equilíbrio. Como conseqüência disto, para os neoclássicos, haverá sempre estabilidade, se a poupança diminuir a taxa de juros cresce e cai a procura por empréstimos e aumenta a vontade de poupar. Se a poupança aumenta muito, a taxa de juros diminui assim como o desejo de poupar, o que resultará em um equilíbrio. Assim, quando a quantidade poupada for igual aos investimentos se chega ao ponto de equilíbrio da taxa de juros e a estabilidade. "Para os neoclássicos, portanto, o normal na atividade econômica é o crescimento estável com algumas flutuações". (AMADO; MOLLO, 2003, p.14). 
A conclusão a que chegam os neoclássicos não é compartilhada pelas demais teorias econômicas. Keynes, ao observar a crise da década de 1930 (caracterizada por um desemprego em massa) passa a contestar a tendência natural a estabilidade econômica proporcionada pelo mercado. Segundo Carvalho (1999, p.21) o que importa destacar é que "para Keynes, economias capitalistas são marcadas pela possibilidade de conflito entre a racionalidade individual e a racionalidade social". Os keynesianos acreditam que não existe nenhum fator que assegure que os vazamentos serão iguais as injeções. A base da teoria keynesiana é que não existe certeza alguma na economia. Isto porque, ao contrário do que acreditam os neoclássicos, a proporção entre poupança/ investimento não é controlada pela mesma variável, a taxa de juros.

A poupança é determinada pela sobra que o trabalhador tem de sua renda. Mesmo que a taxa de juros esteja elevada, só é possível poupar se existir sobra de renda para ser poupada. Alguém que não possui sobra de renda, independente da taxa de juros, jamais poupará. Já o investimento é definido pela eficiência marginal do capital (o quanto os investidores esperam ganhar). Deste modo, se a relação eficiência marginal do capital for superior aos gastos ao contrair o investimento (acrescentando nesta a variável taxa de juros, que pode aumentar ou diminuir os custos do investimento/ empréstimo) o empresário optará por investir. Em suma, o investimento é definido pela eficiência marginal do capital e o seu custo.

Sendo assim, na medida em que ocorrem desproporções entre vazamentos e injeções o sistema descrito na Figura 01 está propenso a crises. A cerca disso, percebemos que não existe certeza alguma com relação à estabilidade econômica. De acordo com Carvalho (1999, p.25) "os keynesianos acreditam que a livre interação entre agentes privados não é capaz de permitir a uma economia explorar seu potencial. Esta incapacidade privada, contudo, pede a intervenção de algum agente externo: o Estado".

O Estado é observado por Keynes como um "rei filósofo" (CARVALHO, 1999, p.22) que é capaz de representar a sociedade de forma melhor do que ela seria capaz de representar-se diretamente. A participação do Estado como interventor também é observada pelos marxistas como benéfica, no entanto, esta só é capaz de representar um paliativo para as crises, não resultando em uma solução definitiva, já que o cerne da crise é a lógica capitalista.

Os marxistas discordam da classificação de trabalho, capital e recursos naturais como fatores de produção. A mão-de-obra, trabalho, é vista como o real gerador dos meios de produção e das mercadorias. Os meios de produção atuam na medida em que 
auxiliam na produtividade da mão-de-obra. Deste modo, "para os marxistas, o lucro, os juros e a renda fundiária pagam apenas a propriedade dos meios de produção. Não pagam a contribuição deles para a produção como o termo 'fatores de produção' indica”. (AMADO; MOLLO, 2003, p.22)

O trabalho é observado como mercadoria. Diante disso, como qualquer outra mercadoria o seu preço é dado pela quantidade de horas despendidas em sua produção, no caso do trabalho, seu valor de produção corresponde aos gastos que o trabalhador tem desde o dia em que nasceu até o momento atual, estes gastos incluem: moradia, alimentação, vestuário, qualificação, educação, entre outros. Todos esses gastos de produção da mercadoria mão-de-obra são pagos com o salário.

A força de trabalho, por outro lado, gera mercadorias de valor maior do que o que se é pago no seu salário e nos instrumentos de trabalho utilizados por este. O valor excedente resultado deste processo é denominado de 'mais-valia', deste valor sairá o lucro do capitalista. A intenção do capitalista é maximizar seu lucro, as únicas formas que podem ser utilizadas para que isso ocorra é aumentar a produtividade ou diminuir a porcentagem do que é pago pela mercadoria força de trabalho.

Caso utilize essa última estratégia de maximização dos lucros irá diminuir o consumo dos trabalhadores por produtos, já que ocorreu uma queda no poder de compra, levando a um subconsumo. Os capitalistas, por sua vez, disponibilizarão de maior capital, no entanto, devem dedicar uma parte considerável deste em investimento, ou perderão competitividade. Se os capitalistas optam por um aumento na produtividade, sem ser acompanhado por um acréscimo de salários (não existe uma propensão dos capitalistas a aumentar salários para que o seu lucro não seja comprometido), a 'superprodução' irá gerar excedente de produção e como conseqüência o desemprego.

Dentro da percepção marxista, a economia sofre de crises constantes acarretadas pela própria lógica capitalista de maximização dos lucros. O Estado se insere como um meio para minorar as tensões, os efeitos da crise, sem, por outro lado, solucionar o problema definitivamente.

Os marxistas acham que soluções via Estado são transitórias e tendem a gerar outros problemas. Para eles, a origem de tais problemas está na lógica da produção capitalista. Portanto, esses problemas não serão completamente eliminados enquanto, essa lógica existir. (AMADO; MOLLO, 2003, p.26). 


\section{2 - As Falhas de Mercado}

Apesar das divergências com relação à percepção da intervenção do Estado, todas as teorias econômicas (neoclássica, keynesianos e marxistas) acreditam que o mercado é passivo de falhas. Para os neoclássicos, no entanto, ainda que o mercado falhe eventualmente, o Governo ao tentar intervir no mercado acaba por incorrer em falhas ainda mais graves, sendo assim, as falhas de Governo sobrepõem as de mercado. Já os marxistas acreditam que o Estado pode reduzir a gravidade dos problemas, mas, como o cerne da questão é o capitalismo, as soluções encontradas por este são sempre transitórias e podem dar origem a outros problemas.

Por falhas de mercado, entendemos aqueles fatores que surgem da própria lógica de funcionamento do mercado e que impedem que seja atingido o ponto de eficiência, o ótimo de Pareto ${ }^{1}$, ou o welfare state. As falhas de mercado, de acordo com Frank (1997, p.575) são três, estas são as seguintes: monopólio, externalidade e bens públicos.

- Bens públicos: as empresas se baseiam principalmente no objetivo do lucro, deste modo, suas ações, investimentos e produtos têm por princípio gerar lucro. Ações que não gerem o lucro desejado não lhes despertam interesse. Sendo assim, aqueles serviços/ bens que são de interesse do público, mas não geram o retorno necessário acabam por ser disponibilizadas pelo Estado. Os bens públicos incorrem em ineficiência porque existe uma impossibilidade de se cobrar adequadamente por eles. Pelo fato de poderem ser consumidos por várias pessoas (não-excludente) sem que diminua a quantidade de sua utilização por outras pessoas (não-rivalidade), correm o risco de serem escassamente produzidos, já que quem investe neles não obtém os resultados dos gastos.

As principais características deles são: a não-rivalidade e a não-exclusividade. Como não existe direito de propriedade qualquer pessoa pode consumi-los, é vedada a exclusão de consumo do bem público. A não-rivalidade se refere ao fato de que a utilização de um bem por um indivíduo não faz reduz a quantidade deste mesmo bem disponível para outras pessoas.

Bens que possuem estas características num elevado grau freqüentemente, conhecidos por bens públicos puros, sendo o exemplo clássico a defesa nacional. Bens que possuam apenas a propriedade da não-rivalidade são, por vezes, designados por bens coletivos. Bens coletivos são, em alguns casos,

\footnotetext{
${ }^{1} \mathrm{O}$ produto é um ótimo de Pareto se, somente se, nenhum agente ou situação pode estar em uma posição melhor sem fazer com que outro agente ou situação assuma uma posição pior.
} 
providos pelo Estado e em outros casos por empresas privadas. A maioria dos bens públicos puros é provido pelo Estado, mas mesmo neste caso existem situações excepcionais em que empresas que buscam lucros possuem esquemas bem delineados para os proverem. (FRANK, 1997, p.620).

- Monopólio: o monopólio ocorre quando uma única empresa detém o controle da comercialização de um produto. "Na economia brasileira, empresas telefônicas já exerceram monopólio, mas as privatizações modificaram tal cenário. Porém, os serviços básicos de energia elétrica e saneamento básico ainda são caracterizados como monopólios”. (DIAS; CASSAR, 2005, p.102)

A respeito da colocação dos monopólios como falhas de mercado nos parece mais correto inserir a denominação de 'comportamentos não-competitivos' ou 'mercados não concorrenciais' e adicionar a este grupo os monopólios, oligopólios, mercado oligopsônio (caracterizado pela pequena quantidade de compradores no mercado e muitos ofertantes), mercado monopsônio (estrutura de mercado com forte controle dos preços, em que, só se encontra um cliente para diversos ofertantes) e a concorrência monopolística.

Os oligopólios são formados quando um determinado setor apresenta apenas um pequeno número de empresas importantes no mercado. Estas empresas produzem todo ou a maior parte dos produtos deste setor.

Já por concorrência monopolista se entende uma estrutura de mercado onde são produzidos bens diferentes (monopólio), entretanto, com substitutos próximos passíveis de concorrência. (FRANK, 1997, p.400).

- Externalidade: correspondem àquelas atividades de produção que envolvem a imposição involuntária de custos ou benefícios. São involuntários porque os indivíduos que recebem estes benefícios ou malefícios não estão diretamente envolvidos nessas atividades. Essas externalidade constituem 'falhas' porque não existem mecanismos de compensação no mercado para elas.

Deste modo, os efeitos sobre estas pessoas podem ser positivos ou negativos, gerando externalidades positivas ou negativas. Como exemplo de externalidades positivas podemos citar o trabalho de algumas ONG que atuam na conservação dos recursos ambientais, pois seus efeitos sobre a sociedade são geralmente muito positivos sem que se tenha que pagar pelo beneficio. O exemplo clássico de externalidade negativa é a poluição ao meio ambiente gerada por algumas 
empresas, ou até mesmo, a poluição sonora que certas indústrias proporcionam a comunidade que habita o entorno.

\begin{abstract}
O conceito de externalidades, provém da constatação de que o postulado da teoria convencional de que o mercado produzia o equilíbrio não só para cada agente individualmente considerado, mas para a economia como um todo, esbarrava no fato de que a ação de certos agentes afetava positiva ou negativamente as ações de outros agentes. Esses efeitos passaram a se chamar externalidades e serviram de base a novos tipos de regulação estatal para coibi-los ou limitá-los. As externalidades mais comuns se dão da produção sobre o consumo e sobre a própria produção, embora também ocorram em sentido inverso, ou seja, do consumo sobre a produção e o próprio consumo. (TEXEIRA, 2001, p.10).
\end{abstract}

Além das falhas de mercado citadas por Frank acrescentamos algumas outras: mercados incompletos e a presença das informações assimétricas.

- Presença de informações assimétricas: o mercado é ineficiente se durante a relação comprador-vendedor uma das partes da relação possui mais informações que a outra, ocasionando assim uma distorção no mercado conhecida como presença de informações assimétricas. Um comprador ou vendedor vai basear suas ações nas informações que possui se estas forem falhas ele agirá com ineficiência. "Sem conhecimento perfeito de todos os aspectos quantitativos e qualitativos que influem no mercado, não se pode esperar do homo economicus uma decisão racional". Teixeira (2001, p. 11).

Desta forma, para o investidor alocar seus recursos com eficiência ele necessita dispor de informações atuais e corretas sobre os projetos (e todos os fatores que os influenciam) aos quais pretende investir, mas, por vezes, os mercados são permeados por informações assimétricas o que dificulta a atuação de investidores de forma eficiente.

- Mercados Incompletos: ocorrem quando há um desequilíbrio entre a quantidade de oferta e o valor que o consumidor esta disposto a pagar. Esta situação necessita da intervenção do Estado em momentos de crises econômicas, onde o fornecedor de um determinado bem essencial pode, por exemplo, se aproveitar de um momento de crise para conseguir mais lucro. 


\section{3 - O turismo como instrumento de desenvolvimento}

Comumente, em especial para os mais leigos, o turismo é sempre pensando como meio eficaz para atingir o crescimento e o desenvolvimento de uma localidade. No entanto, ao pensar no turismo como instrumento de desenvolvimento cabe fazermos algumas considerações.

A princípio devemos observar as formas como o turismo se desenvolve em uma localidade. Estas, segundo Beni (2000, p.80), podem ser as seguintes: Desenvolvimento autóctone, vinculado ao capitalismo popular de empreendedores nativos; Colonização aristocrática, planejada por grandes capitais sobre vasta superfície; e Colonização democrática, caracterizada pelo afluxo dos pequenos investimentos dos cidadãos.

- Desenvolvimento autóctone: neste processo o desenvolvimento tem início com a aplicação de capital individual para que depois com base nesses investimentos seja criado um efeito multiplicador com o envolvimento de grande parcela da comunidade.

Nestes locais surgem, ainda de forma rudimentar, os primeiros equipamentos receptivos e as próprias infra-estruturas de acesso e urbana constituem iniciativa da comunidade, sem nenhum auxílio governamental. Aparecem as primeiras pousadas e hotéis familiares, muito procurados exatamente pela simplicidade das instalações e excelente culinária artesanal. Com o volume sempre crescente de demanda nesses lugares, os investimentos vão se processando em maior densidade; conseqüentemente os equipamentos vão se aprimorando e ampliando sua capacidade receptiva, sem todavia perder as características anteriores de hospitalidade e qualidade dos serviços. (op. cit)

Desta forma, a população local se revela como a grande empreendedora do local, provendo ela mesma a cidade de parte da infra-estrutura necessária para o desenvolvimento do turismo.

- Colonização aristocrática: o turismo tem início com um projeto elaborado por algum órgão público (estadual, municipal ou federal) ou por alguma autoridade financeira em áreas com baixa densidade demográfica e paisagens naturais amenas (praias, montanhas, serras, entre outras). Os projetos remetem a construção de empreendimentos de grande porte, geralmente resorts, que entram em contraste com a realidade da comunidade local.

Aristocrático, o modelo colonizador é quase sempre integral, pois a população dificilmente participa do processo ou mesmo se aproxima dos turistas. Esses equipamentos receptivos não repetem por muito tempo o caráter sazonal. Participam apenas os artesãos e comerciantes próximos do hotel: no 'castelo' que deve dar provas de auto-suficiência, porque velhos e novos senhores têm o comando de uma economia de massa, redescobrindo o 'regime feudal'. Essa ilusão impele, ainda hoje, joalheiros e antiquários, 
modistas e muitos outros a disputar em todo o mundo saguões e espaços dos vários Hilton e Sheraton - no caso brasileiro, hotéis como o Transamérica e o Mediterranée nas ilhas de Itaparica e Comandatuba (BA) - para dar ao cliente a sensação de estar visitando loja de sua propriedade. BENI $(2000$, p.81)

- Colonização democrática: neste modelo, a população local não possui recursos para desenvolver o turismo, sendo assim, recebe investimento de capital externo, mas como já existe uma organização urbana (com alguma densidade demográfica e áreas já ocupadas), o espaço não é apropriado pelo turismo do modo como ocorre na colonização aristocrática. Os investimentos de fora geram um efeito multiplicador que leva benefícios a população local que é utilizada amplamente como mão-de-obra pelo turismo.

As diferentes formas em que o turismo surge nas localidades nos permitem perceber que dependendo do modelo 'escolhido' para promover o turismo, esta atividade pode ou não trazer benefícios para a população local e contribuir de fato para o desenvolvimento da região.

Devemos sempre fazer uma distinção entre os termos 'desenvolvimento' e ‘crescimento'. Ao mencionar a expressão crescimento geralmente esta se encontra atrelada à idéia de aumento quantitativo de divisas, ou de renda. Mas, ao mencionar que uma determinada cidade 'cresceu' turisticamente, isto não implica que a comunidade local obteve melhoras em sua condição de vida. O conceito de crescimento não engloba indicadores sociais, como a distribuição da renda gerada para a população local ou os impactos sociais e ambientais resultantes da interação comunidade local - turistas, mas apenas o aumento de renda e/ou do fluxo de turistas. Já o conceito de desenvolvimento envolve uma preocupação com o social, com a qualidade de vida da população, com a inserção da população nas atividades que geram renda.

Segundo Dias (2003, p.69) o processo de desenvolvimento se dá quando ocorrem os seguintes fatores:

- elevação da renda per capita da população;

- redução das desigualdades na distribuição da renda e entre as regiões;

- alteração na estrutura da formação renda ${ }^{2}$;

- alteração da estrutura da composição industrial ${ }^{3}$;

\footnotetext{
${ }^{2}$ Este item é explicado por Dias como sendo uma "redução da participação do setor primário e aumento do setor industrial e de transportes, por exemplo".

3 “Aumento da participação relativa da produção de bens de capital e de bens intermediários e diminuição da produção de bens de consumo". (op. cit.)
} 
- integração das atividades de todo o sistema econômico, eliminando-se a concentração ou dependência excessiva de setores ou atividades;

- melhoria das condições sociais e culturais da população, com redução do analfabetismo e elevação dos padrões de escolarização;

- ampliação das oportunidades de avanço social, a eliminação de tabus e preconceitos e a melhoria das condições de saúde, nutrição, higiene e habitação da comunidade.

A atual vertente de desenvolvimento turístico apregoada é o desenvolvimento sustentável ${ }^{4}$, baseada em três pilares de sustentação: promover a eqüidade social e econômica mantendo a qualidade ambiental para as gerações futuras.

O desenvolvimento do turismo sustentável atende às necessidades dos turistas de hoje e das regiões receptoras, ao mesmo tempo em que protege e amplia as oportunidades para o futuro. É visto como um condutor ao gerenciamento de todos os recursos, de tal forma que as necessidades econômicas, sociais e estéticas possam ser satisfeitas sem desprezar a manutenção da integridade cultural, dos processos ecológicos essenciais, da diversidade biológica e dos sistemas que garantem a vida. (OMT, 2003, p.24)

O turismo como instrumento de desenvolvimento é bastante contestado, por alguns autores, esta atividade, ao contrário do que muitos pensam, nem sempre constitui algo viável para promover o desenvolvimento da população local. A atividade turística com a finalidade da busca de uma eqüidade sócio-econômica é questionada, já que em nível global o turismo representa mais o papel de concentrador de renda nas regiões centrais do que distribuidor de renda das regiões centrais para as periféricas.

A concentração atual dos fluxos turísticos e a reduzida participação dos países em desenvolvimento no fluxo turístico internacional se apresenta com clareza no fato de que a maior parte dos fluxos turísticos internacionais se realiza entre os próprios países emissores ou desenvolvidos e entre estes e os países com nível de desenvolvimento intermediário. (DIAS, 2003, p.82)

Esta realidade é facilmente observada ao analisar as pesquisas disponibilizadas por órgãos como a OMT, onde percebemos que os três maiores receptores de turistas são França, Espanha e Estados Unidos, todos países desenvolvidos. Os países que recebem mais turistas também são aqueles que mais emitem, deste modo, o turismo a nível global ocorre entre um número relativamente pequeno de países que enviam e recebem alto fluxo de turistas entre si, apenas uma quantidade pequena de turistas das regiões centrais viaja a periferia. Assim, o fluxo de renda se mantém nas regiões

\footnotetext{
${ }^{4}$ Dentro da vertente de desenvolvimento sustentável existe outro modelo também bastante destacado que é a formação de clusters turísticos (planejamento participativo), com integração também de arranjos produtivos locais (APL's) relacionados a atividades de interesse turístico (como produção de alimentos típicos, como queijos, doces, por exemplo).
} 
centrais, ocorrendo pouquíssimos vazamentos para as periferias, ver tabela 01. Neste podemos perceber claramente que o turismo a nível global vem representando uma atividade produtiva principalmente para os países desenvolvidos, trazendo pouco ou nenhum beneficio para os países em desenvolvimento e pobres.

Tabela 01: Maiores Receptores de Turistas

\begin{tabular}{|l|c|c|c|}
\hline \multicolumn{4}{|c|}{ OS DEZ MAIORES RECEPTORES DO MERCADO INTERNACIONAL EM 2002 } \\
\hline PAÍS & $\begin{array}{c}\text { No- DE TURISTAS } \\
\text { (MILHÕES) }\end{array}$ & $\begin{array}{c}\text { PORCENTAGEM (\%) } \\
2001 / 2002\end{array}$ & $\begin{array}{c}\text { PARCELA DE } \\
\text { MERCADO (\%) }\end{array}$ \\
\hline França & 77,0 & 2,4 & 11,0 \\
\hline Espanha & 51,7 & 3,3 & 7,4 \\
\hline Estados Unidos & 41 & $-6,7$ & 6,0 \\
\hline Itália & 39,8 & 0,6 & 5,7 \\
\hline China & 36,8 & 11,0 & 5,2 \\
\hline Reino Unido & 24,2 & 5,9 & 3,4 \\
\hline Canadá & 20,1 & 1,9 & 2,9 \\
\hline México & 19,7 & $-0,7$ & 2,6 \\
\hline Áustria & 18,6 & 2,4 & 2,6 \\
\hline Alemanha & 18,0 & 0,6 & \\
\hline
\end{tabular}

Fonte: Petrocchi (2004, p.152).

Sob uma perspectiva internacional o turismo não nos parece representar uma forma viável de distribuir renda, pelo contrário representa uma atividade que reforça ainda mais a concentração de renda e a dicotomia entre centro e periferia. Uma análise que Ouriques (2005, p.100) e Bem (2005, p.77) fazem sobre o turismo internacional (estrangeiros de países desenvolvidos que visitam o Brasil) é de que a atividade representa uma forma de neocolonialismo e dependência, ilustrada atualmente pela grande presença de turistas que visitam o Nordeste com o objetivo de praticar o turismo sexual.

O turismo doméstico, por outro lado, apresenta uma dinâmica distinta. Se analisarmos os fluxos turísticos no Brasil notamos que apesar das cidades de São Paulo e Rio de Janeiro, e da Região Sudeste como um todo representarem a maior receptora de turistas no Brasil, esta também é a região que mais emite turistas também. Como o Nordeste é a segunda região que mais recebe turistas, percebemos que uma grande parte dos turistas que visitam o Nordeste são naturais da Região Sudeste, que também é a região mais desenvolvida do país. 
Tabela 02: Mercado do Turismo Brasileiro por Região

\begin{tabular}{|c|c|c|c|c|}
\hline \multicolumn{5}{|c|}{$\begin{array}{r}\text { EVOLUÇÃO E COMPOSIÇÃO DO MERCADO } \\
\text { BRASILEIRAS }\end{array}$} \\
\hline Local & 1998 (turistas x 1000) & $(\%)$ & 2001 (turistas x 1000) & $(\%)$ \\
\hline Brasil & 38.200 & 100 & 41.300 & 100 \\
\hline Sudeste & 14.480 & 38 & 17.997 & 44 \\
\hline Sul & 6.188 & 16 & 7.603 & 18 \\
\hline Nordeste & 12.190 & 32 & 12.023 & 29 \\
\hline Centro-Oeste & 2.393 & 6 & 2.730 & 7 \\
\hline Norte & 2.872 & 8 & 990 & 2 \\
\hline
\end{tabular}

Fonte: Petrocchi (2004, p.174).

Mas devemos destacar algumas características próprias da atividade. Um dos argumentos utilizados largamente pelos entusiastas do turismo é a criação de empregos para a população local, como vimos anteriormente nem sempre isso ocorre, mas considerando hipoteticamente que se trate de um modelo que a população local se 'beneficie' com a utilização da sua mão-de-obra, estes postos de trabalho em sua maioria representam cargos operacionais mais básicos. Para ilustrar este fato, pensemos na quantidade, e na qualidade, das vagas criadas por um hotel. Imaginando o quadro funcional da empresa hoteleira existem apenas as vagas de gerente geral/ assistente de gerência; e coordenadores de setores/ assistentes de coordenadores de setores que recebem melhores salários, contudo, há uma imensa maioria composta por garçons, commis, stewards, camareiras, mensageiros, recepcionistas, jardineiros, seguranças, etc., que recebem baixos salários. Além do mais, o mercado de trabalho na área de turismo é caracterizado pelo grande número de empregos informais criados.

\begin{abstract}
A possibilidade de gerar empregos sempre foi um elemento motivador dos programas de fomento à atividade turística em todo o mundo. Trata-se de um ponto fundamental para o incremento dos discursos do empresariado do setor, bem como dos órgãos da administração pública, que se valem de cifras, muitas delas produzidas para impressionar o grande público, justificando assim boa parte dos gastos com o setor, bem como para 'desculpar' os abusos cometidos por alguns empresários, que, em nome desse 'benefício social', provocam graves impactos ambientais, como custo a ser pago pelas maravilhosas promessas de ocupação produtiva para as coletividades envolvidas. Portuguez (2002, p. 114).
\end{abstract}

A colocação de que o turismo representa uma atividade produtiva que gera empregos em segmentos 'excluídos' (pessoas com baixa qualificação e mulheres) pode 
ser contraposta pela qualidade destes empregos, pelo baixo salário e pela alta informalidade.

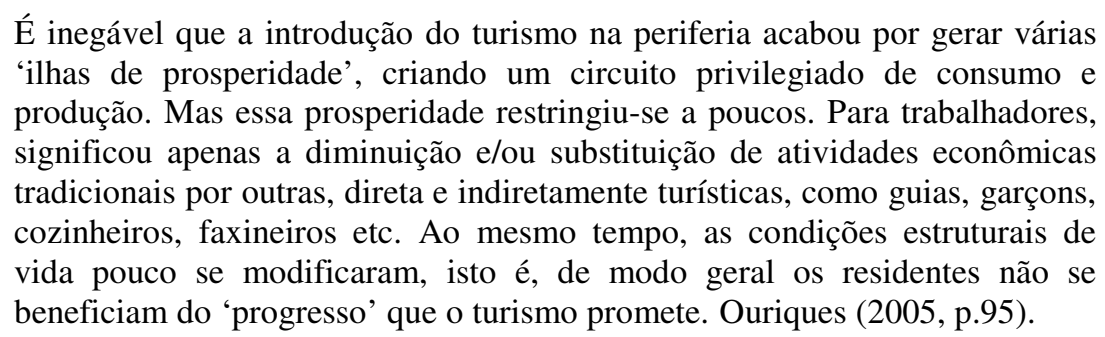

A atividade turística como meio de desenvolvimento necessita da intervenção do Governo através de políticas públicas. Ao Governo cabe, todavia, ter uma visão mais ampla do turismo, bem diferente da visão simplista (presente em várias políticas tanto públicas como privadas de turismo) da indústria sem chaminés que traz sempre empregos e benefícios para os núcleos receptores.

O discurso de que todos ganham com o turismo é superficial e mantido apenas na aparência, pois, na essência do fenômeno, verifica-se que há contradições, pois, muitos são explorados. Uma minoria se apropria da riqueza gerada por essa atividade que explora o trabalho de muitos, além dos recursos naturais, com parte deles privatizados (inclusive praias), com a manipulação dos meios e vias de comunicação e degradação dos ambientes necessários à manutenção da vida. (CORIOLANO, 2006, p.68).

Ao ignorar os impactos negativos não são buscadas soluções eficazes para seus problemas tais como o turismo sexual, a degradação ambiental, a 'privatização' de ambientes (bens) públicos, a exclusão da população local no desenrolar da atividade, entre outros.

Ao Governo cabe, através das políticas públicas, realizar intervenções com o objetivo de implementar o turismo e medidas que visem 'corrigir' as consequiências trazidas pelo mercado (tais como as enunciadas acima), defender o interesse público, atuar como regular/ legislador da atividade turística, procurando assegurar a integridade dos ecossistemas e das pessoas (por meio de políticas/ leis que inibam o turismo sexual, por exemplo), incentivar o turismo (por meio principalmente da realização de pesquisas e marketing de destinações como faz a EMBRATUR) e coordenar os diferentes setores (trade turístico, comunidade local e Governo - Federal, Estadual, Municipal) na busca de um objetivo comum, o desenvolvimento de turismo com base sustentável. 


\section{TURISMO E INFRA-ESTRUTURA}

\section{1 - Componentes do Turismo}

O deslocamento sempre esteve presente na história da humanidade. A princípio, como fator determinante da sobrevivência das civilizações pré-históricas nômades. Com o passar dos séculos e o desenvolvimento das civilizações, as viagens foram se destacando de outras formas. Elas deixaram de representar a sobrevivência e passaram a serem vistas como o meio para conquista de novos territórios, cura de doenças, busca de religiosidade e lazer.

Dentro deste contexto, duas civilizações merecem destaque. Foram elas: a civilização romana e a grega. Os gregos viajavam constantemente em busca de espetáculos culturais, festivais e jogos. Já os romanos desenvolveram locais destinados unicamente ao repouso. A principal criação da civilização romana, com relação aos espaços de lazer, foi o 'circo' (arena). Estes espaços comportavam eventos esportivos diversos, o mais famoso foi à luta de gladiadores entre si e com feras.

De acordo com Lage e Milone (1996, p.16) apud Delgado (2006, p.68) apesar da grande importância das civilizações clássicas para o histórico das viagens, foi somente a partir da metade do século XIX que as viagens passaram a ser chamadas de viagens turísticas. O desenvolvimento da atividade turística, nos moldes atuais, surge como consequiência do avanço tecnológico iniciado pela Revolução Industrial e da formação da classe burguesa. A tecnologia trazida pela Revolução Industrial possibilitou novas construções em ferro fundido, a exemplo das linhas de ferro em Londres, construção de arranha-céus, Torre Eiffel etc.

A classe burguesa se destaca na história da evolução das viagens em função dos Grand Tour. Estas viagens eram realizadas principalmente pelos jovens burgueses como forma de demonstrar status e também como ferramenta de exploração de novos lugares, forma de adquirir conhecimento e mostrar seu poder econômico. Ainda que já existisse uma relativa organização nos períodos passados, apenas a partir da segunda metade do século XIX, em torno de 1841, é que começou o que se pode chamar de fato de viagens turísticas e turismo. Os grandes responsáveis por essa maior organização foram: Thomas Cook, Henry Wells, George Pullmann, Thomas Bennett, Louis Stangen e César Ritz. 
As novas possibilidades da engenharia começaram a mudar a aparência das grandes cidades do mundo, assim como seus meios de transporte. Neste período se iniciou o desenvolvido de dois meios de transportes de suma importância para o crescimento do turismo, estes foram os navios de passageiros e os trens.

O turismo no século XIX era caracterizado como residencial, ou seja, as pessoas ficavam um período ou uma estação do ano em uma segunda residência. A viagem, ou temporada, era motivada por questões de saúde, clima ou descanso das atividades rotineiras do ano e durava de poucas semanas a dois ou três meses. Havia o turismo residencial termal, que era dirigido às estações de águas européias, precursoras dos modernos spas. (TRIGO, p.14, 2002).

O turismo sofre uma época de estagnação no período das $1^{\mathrm{a}}$ e $2^{\mathrm{a}}$ Guerras Mundiais. Ao final da $1^{\mathrm{a}}$ Guerra Mundial, o turismo, principalmente na Europa, experimentou um breve período de expansão interrompido com o início dos movimentos fascistas e nazistas que deram origem a $2^{\mathrm{a}}$ Guerra Mundial. Ao final da $2^{\mathrm{a}}$ Guerra Mundial, a atividade turística ressurge com características distintas daquela realizada no século XIX. O turismo passa a ser efetuado por grandes grupos de pessoas, viajando para destinos já solidificados. Este tipo de viagem ficou conhecido como 'turismo de massa'.

Nos anos 50, a viagem internacional foi se tornando cada vez mais acessível a uma parcela maior da população devido a diferentes fatores, como o aparecimento do avião a jato para passageiros no final da $2^{\circ}$ Grande Guerra, o baixo preço do petróleo, a maior renda disponível das famílias, o aparecimento das férias remuneradas e o aumento do tempo livre. O desenvolvimento das comunicações e dos meios de transporte foram fatores determinantes que ampliaram as possibilidades de chegar a novas e mais distantes regiões de recebimento ou destino turístico. OMT (2001, p.34).

Com o desenvolvimento da atividade turística foi surgindo no meio acadêmico a preocupação em entender de que forma esta atividade poderia influenciar nossa sociedade. Assim o turismo passou a ser estudado por diversos campos profissionais, dentre eles: a geografia, economia, sociologia. Cada uma destas áreas entende o turismo de modo diferenciado, sempre enfatizando seu objeto de estudo. Uma possível definição destaca a atividade turística como agente consumidor e dependente do espaço geográfico, caracterizando este como o principal elemento atrativo do turismo, a saber:

"O turismo é antes de mais nada uma prática social, que envolve o deslocamento de pessoas pelo território e que tem no espaço geográfico seu principal objeto de consumo.” (CRUZ, 2003, p.5)

Uma outra acentua o efeito multiplicador e as divisas trazidas pelo desenvolvimento do turismo nos núcleos receptores. 
O turismo, na sociedade moderna, pode ser considerado um conjunto de atividades econômicas diversas que englobam os transportes, os meios de hospedagem, os agenciamentos de viagens e as práticas de lazer, além de outras ações mercadológicas que produzem riqueza e geram empregos para muitas regiões e países. (LAGE; MILONE, 2000, p.117).

As viagens turísticas se diferenciam dos outros tipos de viagens por englobarem os fatores inerentes ao turismo, que são os seguintes: a temporalidade, a permanência fora do domicílio e o objeto do turismo, segundo Beni (2000, p.35). O objeto do turismo seriam os elementos concretos relacionados ao turismo, tais como os equipamentos receptivos do local visitado.

Com relação às definições feitas sobre o turismo, o mais importante é que elas contenham os fatores inerentes ao turismo, já que estes fatores têm como função diferenciar o turismo das outras 'atividades produtiva' ${ }^{5} \mathrm{O}$ conceito de turismo aceito oficialmente é da OMT (2001, p.38):

O turismo compreende as atividades que realizam as pessoas durante suas viagens e estadas em lugares diferentes ao seu entorno habitual, por um período consecutivo inferior a um ano, com finalidade de lazer, negócios ou outras.

Apesar de parecer pouco abrangente o conceito da OMT engloba as principais características diferenciadoras da atividade turística.

Ao analisar a atividade turística não podemos deixar de mencionar seus componentes principais que são: a demanda, a oferta e o mercado. A demanda (ou procura turística) corresponde aos consumidores do turismo, os turistas, que segundo a Organisation de Coopération et Développement Économique (OCDE apud Ruschmann, 1995, p.35) seriam "todas as pessoas que se deslocam do seu local de residência por mais de 24 horas, seja por motivo profissional, recreacional ou qualquer outro motivo". Podendo esta para fins de pesquisa ser dividida em demanda real, potencial ou nula (inexistente). As empresas de turismo procuram sempre trabalhar com as duas

\footnotetext{
${ }^{5}$ Molina (2001, p.29) questiona a classificação da atividade turística como produtiva na América Latina, para ele os serviços são considerados improdutivos. "Para falar de desenvolvimento econômico é necessário não apenas aumentar o Produto Nacional Bruto, mas incrementar atividades econômicas produtivas. Estas por meio da organização do trabalho, dos recursos naturais e do capital, são as que geram bens destinados ao consumo da população, à elaboração de outros bens ou à troca. Em consequiência disso, as atividades econômicas improdutivas ou não produtivas não deixam qualquer expressão material dos fatores produtivos nelas empregados, como é o caso específico dos serviços. Mesmo quando não são produtivas, as atividades econômicas do setor terciário são necessárias para absorver o excedente de renda gerado pelos setores primário e secundário. Entretanto, não se pode obter um desenvolvimento econômico mediante o impulso de atividades improdutivas (terciárias), porque não se aumenta a reserva de bens de consumo e de capital, ou seja, não se gera acumulação". (grifo nosso).
} 
primeiras, tentando manter a real e estudar formar de tornar a demanda potencial em real, através do marketing.

A oferta é tudo aquilo que é oferecido ao consumidor (turista) por um determinado preço e em um período, através do mercado. O produto turístico pode ser definido como todos os produtos que são colocados à disposição dos viajantes pelas várias empresas que atuam na área, como por exemplo, o número de quartos (ou unidades habitacionais - UHs) que disponibiliza um hotel, a quantidade de mesas que oferece um restaurante, as cabines de um trem, pacotes de uma agência de viagens, etc. Este produto é composto fundamentalmente pelos: atrativos ou recursos (que podem ser reais ou potenciais; naturais ou culturais), infra-estrutura (de acesso e básica urbana), equipamentos e serviços (turísticos e de apoio).

Com relação à oferta turística algumas considerações devem ser feitas. Entendemos que a atividade turística (e por consequiência o produto/ oferta turística), ao contrário da maioria dos outros produtos, depende de um amálgama de serviços/equipamentos para ser comercializado.

Quadro 01: Componentes Diretos do Produto Turístico

\begin{tabular}{|c|c|c|c|c|c|}
\hline Alimentação & Hospedagem & Transportes & $\begin{array}{c}\text { Serviços } \\
\text { Complementares }\end{array}$ & Comércio & $\begin{array}{c}\text { Equipamentos de } \\
\text { Lazer }\end{array}$ \\
\hline $\begin{array}{l}\text { - Restaurantes } \\
\text { - Lanchonetes } \\
\text { - Docerias } \\
\text { - Cafés } \\
\text {-Comida típica } \\
\text { - Pubs } \\
\text { - Bares } \\
\text { - Entre outros }\end{array}$ & $\begin{array}{l}\text { - Hotéis } \\
\text { - Campings } \\
\text { - Pousadas } \\
\text { - Casas } \\
\text { - Flats } \\
\text { - Lodges } \\
\text { - Albergues } \\
\text { - Entre outros }\end{array}$ & $\begin{array}{l}\text { - Ônibus } \\
\text { - Navio } \\
\text { - Avião } \\
\text { - Trens } \\
\text { - Carros }\end{array}$ & $\begin{array}{l}\text { - Locadoras de } \\
\text { automóveis } \\
\text { - Agências de } \\
\text { viagem } \\
\text { - Guias de turismo } \\
\text { - Outros serviços }\end{array}$ & - souvenir & $\begin{array}{l}\text { - Aluguel de } \\
\text { equipamentos } \\
\text {-Parques esportivos } \\
\text { - Cinemas, teatros } \\
\text { - Centros de lazer } \\
\text { - Parques naturais } \\
\text { - Parques de } \\
\text { diversão } \\
\text { - Parques temáticos } \\
\text { - Entre outros }\end{array}$ \\
\hline
\end{tabular}

Fonte: Adaptado de Petrocchi (2004, p.75).

O mercado é o meio pelo qual o produto turístico (oferta) chega até seu consumidor final (demanda real). É a ponte de comunicação entre o produto turístico e o turista.

O turismo depende do funcionamento de vários elementos tais como hotelaria, agenciamento, alimentação, transportes, disponibilidade de atrativos, saneamento básico, água, energia elétrica, dentre outros, para que a localidade possa de fato ser considerada um núcleo receptor e receber turistas. 
Devido a essa característica própria da atividade turística, Beni (2000, p.44) entende que o turismo deve ser estudado segundo a teoria geral dos sistemas. A Teoria Geral dos sistemas:

[...] afirma que cada variável, em um sistema específico, interage com todas as outras variáveis desse sistema e com as de outros sistemas que com ele realizam operações de troca e de interação, explicando e desenhando as configurações aproximadas da dinâmica da vida real. (op. cit.)

O Sistema de Turismo (SISTUR) de Beni entende o turismo como um sistema aberto $^{6}$, procurando demonstrar a complexidade da atividade turística, ilustrando que para a realização do turismo não é necessário apenas a presença de atrativos.

Figura 02: Sistema de Turismo (SISTUR)

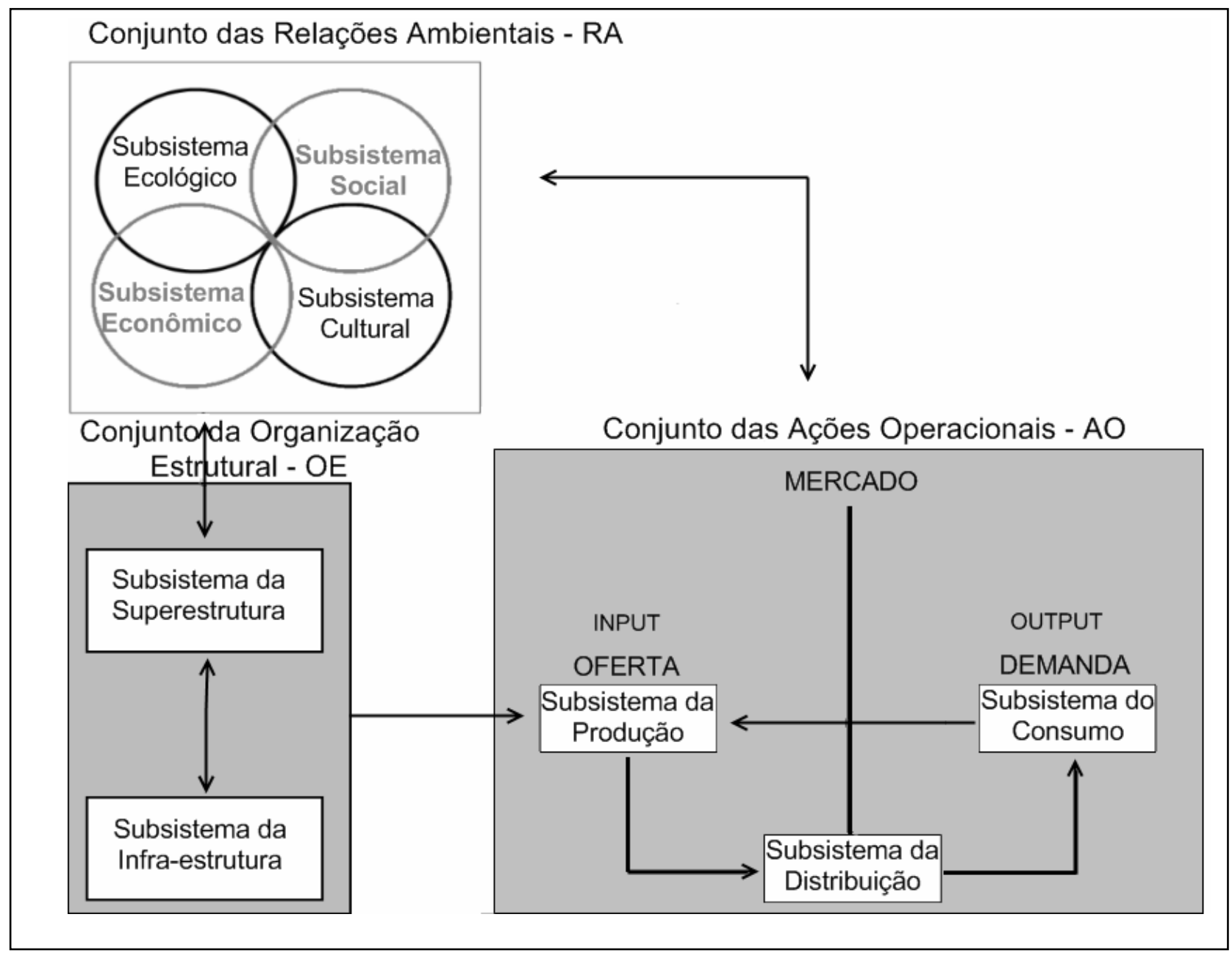

Fonte: Beni (2000, p.48).

\footnotetext{
${ }^{6}$ Um sistema aberto segundo Petrocchi (2004, p.37 apud Chiavenato, 1987) pode ser entendido como "um grupo de unidades combinadas que formam um todo organizado e cujo resultado é maior que o resultado que as unidades poderiam ter se funcionassem independentemente; este conjunto está constantemente se relacionando com outros".
} 
O SISTUR é formado por três conjuntos: conjunto das relações ambientais (ecológico, social, cultural, econômico); conjunto da organização estrutural (superestrutura e infra-estrutura) e pelo conjunto das ações operacionais (produção, distribuição e consumo). Como percebemos pela Figura 02, todos os conjuntos se relacionam constantemente. A grosso modo, poderíamos explicar o primeiro conjunto, RA, como sendo aquele formado pelos recursos tanto ecológicos como culturais, incluindo também a população local, entendida como residentes/comerciantes/trade, população flutuante (visitantes/viajantes) e as relações capitalistas, aqui representadas pelo subsistema econômico. Assim, este conjunto representa uma localidade ao seu estado natural, sem nenhuma espécie de intervenção externa. Num segundo momento, observamos o conjunto OE formado pelas intervenções do Governo e da iniciativa privada através principalmente de programas de capacitação profissional, políticas públicas e do fornecimento de infra-estrutura turística e urbana.

Finalmente, podemos perceber que o conjunto RA corresponde ao que convencionamos chamar popularmente de 'vocação turística', as praias, cachoeiras, rochedos, danças, folguedos, representações religiosas, mão-de-obra, entre outras, no entanto, para que possamos mudar a denominação de 'vocação turística' para 'atrativo turístico’ devemos somar ao primeiro conjunto os elementos do segundo.

A 'matéria-prima' do turismo é o atrativo turístico, este só é formado se além dos recursos potenciais do local existir também infra-estrutura. Apenas a partir de uma intervenção do Governo e do mercado, através da iniciativa privada, fornecendo infraestrutura e elaborando políticas públicas de fomento é que a vocação poderá se concretizar em atrativo.

A infra-estrutura pode ser entendida como o conjunto de instalações necessárias para o desenvolvimento do turismo, estas são as seguintes:

- Infra-estrutura de acesso: consiste nas construções que possibilitam a chegada de pessoas até o destino, elas são formadas pelas estradas, aeroportos, portos, marinas, rodoviárias, etc.;

- Infra-estrutura básica urbana: são as obras que tornam as cidades habitáveis para a população (residente ou flutuante). Ela é formada pelas ruas, avenidas, esgotamento sanitário, saneamento básico;

- Equipamentos turísticos: são as edificações que tornam possíveis a prestação dos serviços diretamente voltados ao turismo. Consiste nas construções físicas 
de tudo aquilo que é utilizado para o turismo, a exemplo dos hotéis, das pousadas, agências, operadoras, transportadoras;

- Equipamentos de apoio: são as instalações que permitem a prestação de serviços que não são exclusivamente turísticos, mas que geralmente são utilizados pelos turistas, como as farmácias, os shoppings, os supermercados, entre outros.

Apenas quando somados o conjunto da RA e da OE é que o produto turístico é formado, constituindo o subsitema de produção, e deste modo, ele pode ser comercializado através do mercado pelo subsistema de distribuição, chegando ao consumidor.

Determinados tipos de infra-estrutura, a exemplo do saneamento básico, são considerados bens públicos, cabendo exclusivamente ao Governo seu fornecimento. Por esta razão, e pela iniciativa privada ter que seguir as leis impostas pelo Estado (na figura de seus instrumentos normativos), o subsistema da superestrutura se localiza acima do subsistema da infra-estrutura, já que o Governo em conjunto com a iniciativa privada são os responsáveis pela sua provisão.

Figura 03: Subsistema da Infra-estrutura do SISTUR

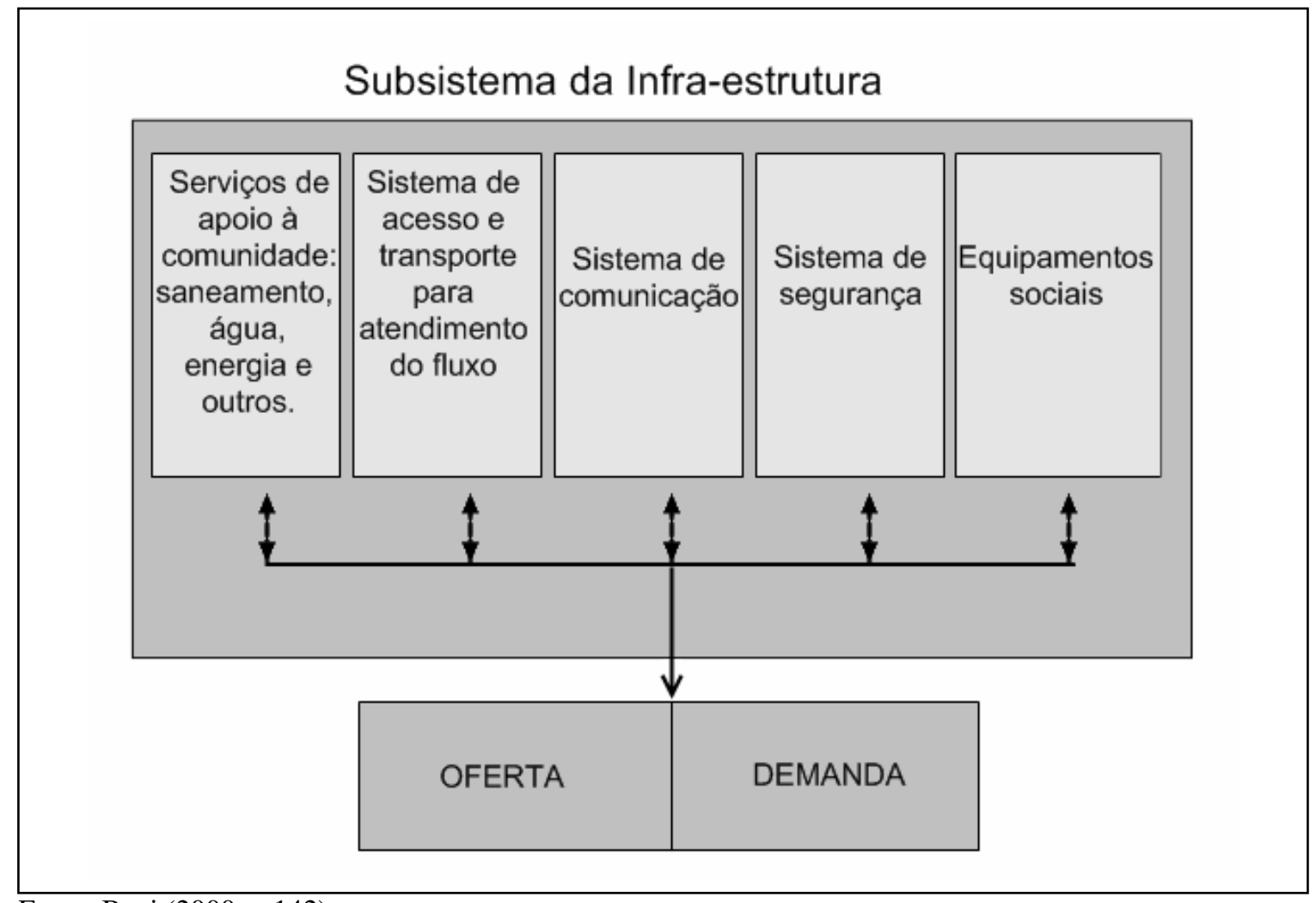

Fonte: Beni (2000, p.142). 
A infra-estrutura urbana, apesar de não representar um item cuja sua construção visa exclusivamente atender as necessidades do turismo, representa elemento fundamental para que este se desenvolva.

Os serviços de infra-estrutura urbana/ básica que são essenciais para o desenvolvimento do turismo são os seguintes:

- Saneamento básico: que se subdivide em abastecimento de água; coleta e disposição de águas residuárias; acondicionamento, coleta e transporte e destino final do lixo; controle da poluição das águas e do ar; extermínio de artrópodes e roedores; higienização de habitações, de locais públicos e de trabalho;

- Sistema de transportes: construção de ruas, estradas, rodovias, portos, aeroportos, marinas, rodoviárias, fornecimento de transporte coletivo de qualidade (ônibus, trens, metros, etc.);

- Serviços: fornecimento dos serviços de comunicação, energia, iluminação pública, limpeza pública, segurança, educação, entre outros.

$\mathrm{Na}$ verdade, a implantação de infra-estrutura se encontra mais relacionado ao desenvolvimento de uma localidade como um todo do que, unicamente, com o desenvolvimento do turismo.

A construção de estradas, por exemplo, favorece o turismo, na medida que, permite a utilização destas por ônibus de turismo e por pessoas que desejam viajar em automóveis (sejam estes próprios ou de aluguel), por outro lado, também pode representar um maior desenvolvimento da agricultura ao qual se utilizará da estrada para escoar os seus produtos, ou mesmo pode aumentar o número de consumidores que vão até o local com o intuito de consumir estes produtos agrícolas. Pode consistir num desenvolvimento do setor imobiliário, com uma valorização (em alguns casos até mesmo especulação) de terrenos e casas.

O desenvolvimento de infra-estrutura, a exemplo da infra-estrutura de acesso, facilita o fluxo de pessoas para o destino o que em muitos casos pode ser considerado positivo para todos. Por outro lado, pode representar a chegada de novos concorrentes para a base produtiva local, que caso não tenha uma estrutura competitiva forte pode ser prejudicada. A chegada de concorrentes pode, também, representar o incentivo necessário para que a base produtiva local busque uma melhoria em termos, por exemplo, de qualidade para ter condições de disputar com os novos concorrentes pelo mercado local beneficiando assim o consumidor e as próprias empresas locais. 
Sendo assim, o desenvolvimento de infra-estrutura básica/ urbana contribui para o aumento da competitividade de uma determinada localidade. Atraindo não só novos moradores, como também indústrias, turistas, eventos, criando empregos, etc. A relação entre infra-estrutura e desenvolvimento é largamente conhecida por todos.

Kotler (1994, p.37) comenta a importância de se desenvolver os 'fatores de marketing' (atrações, imagem, qualidade de vida, pessoas e infra-estrutura) de uma localidade para que estas consigam resolver seus problemas e atrair turistas, moradores, indústrias e aumentar a exportação, se tornando assim mais competitivas e desenvolvidas.

Ao mencionar a infra-estrutura como um dos fatores que promovem o desenvolvimento Kotler (1994, p.43) afirma que:

Com certeza nem a imagem nem as atrações podem dar a resposta completa ao desenvolvimento de um local. Um lugar tem de funcionar (grifo nosso). Seus cidadãos e visitantes têm de ter bons meios de transporte. A cidade tem de fornecer energia suficiente e barata a seus cidadãos e empresas, e não uma série de blackouts. As escolas devem dar educação de qualidade. As pessoas devem poder andar com segurança pelas ruas e não temer por suas vidas. A água deve ser potável, os códigos e normas de construção de edifícios devem ser reforçados, deve-se fornecer espaço recreativo, bons hotéis e restaurantes.

A infra-estrutura é vista por Petrocchi (2004, p.37) como um dos elementos que irá formar a imagem do lugar. Sendo a imagem o item que realmente atrai o turista e que definirá o êxito de uma localidade, com relação à atração de atividades que gerem renda para a cidade.

O destino concorre no mercado do turismo com o propósito de atrair visitantes e mantê-los como clientes. Sua sobrevivência econômica dependerá da construção de uma imagem atraente, que por sua vez é função de seus atrativos naturais e artificiais, de serviços eficientes, da qualidade do meio urbano e de adequadas infra-estruturas, condições essas que contribuem para ser escolhido pelas pessoas para o propósito de uma visita. (op. cit.)

O autor coloca ainda que a imagem da destinação é medida por uma variável denominada coeficiente de atração turística (CAT), esta contém os seguintes itens: natureza exuberante; infra-estrutura; hospitalidade; qualidade dos serviços prestados; gastronomia; folclore/cultura; ações de marketing e diferenças entre origem e destino.

Assim, podemos notar que apesar de existirem divergências com relação a posição da infra-estrutura dentro do produto turístico/ sistema do turismo, todos os autores concordam que a disponibilidade de infra-estrutura, em todos os níveis (turística, de acesso, básica urbana, de apoio ao turismo), representa fator fundamental para o desenvolvimento de atividades produtivas, incluindo neste o turismo. 


\section{2 - Intervenção Estatal, Desenvolvimento Regional e Políticas Públicas de}

\section{Turismo}

Como vimos anteriormente, as correntes econômicas possuem opiniões distintas a respeito das intervenções no mercado. Para aqueles que acreditam que o mercado não atua como um bom regulador e que a ação do Estado é imprescindível, o argumento é que o mercado é ineficiente devido às falhas enunciadas. Outra justificativa, utilizada por algumas pessoas, para a intervenção estatal é que existe uma gama de indivíduos que se encontram excluídos do mercado, ou seja, estes não possuem nenhum fator de produção (mão-de-obra, terra, capital) para ofertar ao mercado, sendo excluídos e marginalizados.

Com base na idéia da exclusão dos indivíduos podemos ampliá-la e chegar a uma exclusão de regiões. Segundo Cano e Guimarães Neto (1986, p.167):

O Brasil constitui um país privilegiado para o estudo do desenvolvimento desigual do capitalismo. Formado por 'arquipélagos regionais'. [...] A resultante desse processo pode ser sintetizada nas profundas diferenças sociais, culturais e de níveis de vida que existem atualmente nas regiões brasileiras.

Assim as trajetórias diferenciadas de crescimento das regiões brasileiras também constituem uma outra justificativa para as intervenções estatais, isso porque o mercado não possui os mecanismos necessários para promover uma eqüidade. Sobre a formação destas desigualdades regionais Bem (2005, p.22) afirma que:

Desde o século XVIII, com o desenvolvimento da mineração em Minas Gerais e o conseqüente deslocamento do pólo hegemônico para o Sudeste do Brasil, a região Nordeste perdeu e não conseguiu mais recuperar a hegemonia econômica e política característica dos séculos XVI e XVII. A partir desse momento histórico, consolidou-se na economia nacional uma 'dinâmica da desigualdade', explicitada pela compartimentação de suas regiões em 'zonas ativas' e 'zonas passivas' e produtora de um 'efeito de dominação' das primeiras sobre as segundas. Desde fins do século XIX e início do século $\mathrm{XX}$, a cafeicultura transformou-se no núcleo mais dinâmico da economia brasileira, fazendo com que a região Sudeste passasse a apresentar as taxas mais elevadas de crescimento. A partir de 1930 (particularmente das décadas de 1940 e 1950), fundam-se as bases da economia urbana e industrial moderna, que passaram a exigir a concentração física dos meios de produção, do mercado consumidor e da força de trabalho no Sudeste do país. Com a criação de uma infra-estrutura urbano-industrial nessa região, os investimentos modernizadores ai concentrados aumentaram de modo acentuado as diferenças regionais e contribuíram para consolidar uma relação dicotômica entre 'centro' e 'periferia'. 
Com a constatação de que os países e regiões apresentavam trajetórias de crescimento diferenciadas, dicotomia centro x periferia, são pensadas formas de desenvolver locais periféricos. A partir da década de 1950 começam a ser pensadas, de modo mais consistente, ferramentas para diminuir as disparidades. As primeiras políticas com o objetivo de diminuir as divergências regionais no Brasil são focalizadas para a implantação de indústrias com a intenção de que estas criassem uma dinâmica que aquecesse a economia local.

Apenas em torno da década de 1960, no entanto, é que são pensadas em ações de desenvolvimento do turismo como forma de crescimento de regiões pouco desenvolvidas. O grande marco desta época é a criação da Empresa Brasileira de Turismo (EMBRATUR) em 1966 e a elaboração do primeiro megaprojeto de desenvolvimento do turismo (Projeto Parque das Dunas Via Costeira) no Rio Grande do Norte no final da década de 1970.

Assim, a EMBRATUR, algumas vezes em parceira com a Superintendência de Desenvolvimento do Nordeste (SUDENE) e o Banco do Nordeste, como no caso do PRODETUR/ NE, iniciam projetos de desenvolvimento do turismo, em especial no Nordeste.

Abaixo podemos observar o Quadro 02 que resume as intervenções do Governo no mercado com a intenção de dinamizar a atividade turística no Brasil, e as diversas vinculações institucionais do turismo. Percebemos, pelo quadro, a crescente importância dada ao turismo, que a princípio, em 1946, se encontra vinculado ao Ministério da Justiça e Negócios, e mais recentemente, em 2003, possui seu próprio Ministério.

Quadro 02: Períodos e Ações Governamentais em Prol do Turismo

\begin{tabular}{|c|c|}
\hline Período & $\begin{array}{c}\text { Vinculação institucional e marcos da intervenção governamental no } \\
\text { turismo }\end{array}$ \\
\hline $1937-1945$ & $\begin{array}{l}\text { - Proteção de bens históricos e artísticos nacionais } \\
\text { - Fiscalização de agências e venda de passagens }\end{array}$ \\
\hline $1946-1947$ & Ministério da Justiça e Negócios \\
\hline $1948-1958$ & $\begin{array}{l}\text { Ministério do Trabalho, Indústria e Comércio. } \\
\text { - Intervenção estatal percebida na criação de órgãos e instituições normativas e } \\
\text { executivas, e na produção do espaço. } \\
\text { - Início do planejamento do turismo em nível nacional (COMBRATUR - } \\
\text { Comissão Brasileira de Turismo). }\end{array}$ \\
\hline $1959-1962$ & Subordinação direta à presidência da República (COMBRATUR). \\
\hline $1963-1966$ & $\begin{array}{l}\text { Ministério da Indústria e Comércio (Divisão de Turismo e Certames do } \\
\text { Departamento Nacional do Comércio). } \\
\text { - Modernização e expansão do aparelho administrativo do Estado e sua }\end{array}$ \\
\hline
\end{tabular}




\begin{tabular}{|c|c|}
\hline & $\begin{array}{l}\text { correspondência com os diversos níveis de federação, tendo como marca a } \\
\text { hierarquização/ centralização dessa estrutura. } \\
\text { - Ação mais rígida de controle. } \\
\text { - Criação da EMBRATUR e do Conselho Nacional de Turismo (CNTUR) } \\
\text { - Definição da Política Nacional de Turismo. }\end{array}$ \\
\hline 1971 & $\begin{array}{l}\text { - Criação de incentivos fiscais como o Fundo Geral do Turismo (FUNGETUR) } \\
\text { pelo Decreto-lei } n^{\circ} 1.191 \text {, de } 27 \text { de outubro. }\end{array}$ \\
\hline 1973 & $\begin{array}{l}\text { - Disposição sobre as zonas prioritárias para o desenvolvimento do turismo } \\
\text { (Decreto-lei } n^{\circ} 71.791 \text { de 1977). }\end{array}$ \\
\hline $1985-1986$ & $\begin{array}{l}\text { - Liberação do mercado para o exercício e a exploração de atividades turísticas } \\
\text { e conseqüente redução da clandestinidade e aumento do número de agências } \\
\text { registradas. } \\
\text { - Criação do 'Passaporte Brasil' para a promoção do turismo interno } \\
\text { - Estímulo à criação de albergues. }\end{array}$ \\
\hline 1987 & $\begin{array}{l}\text { - Incorporação das questões ambientais na formulação das políticas públicas. } \\
\text { - Lançamento, pela EMBRATUR, do turismo ecológico como novo produto } \\
\text { turístico brasileiro. }\end{array}$ \\
\hline 1988 & $\begin{array}{l}\text { - O turismo é citado na Constituição brasileira em seu art. 180, no qual se } \\
\text { atribui responsabilidades iguais a todos os níveis governamentais. }\end{array}$ \\
\hline 1992 & $\begin{array}{l}\text { Ministério da Indústria, do Comércio e do Turismo. } \\
\text { - Revitalização do FUNGETUR e dos incentivos fiscais do setor } \\
\text { - Apresentação do Plano Nacional de Turismo (PLANTUR) } \\
\text { - Criação do Programa de Desenvolvimento do Turismo no Nordeste } \\
\text { (PRODETUR-NE) }\end{array}$ \\
\hline $1993-1994$ & $\begin{array}{l}\text { - Implantação do PRODETUR-NE } \\
\text { - Lançamento de diretrizes para uma Política Nacional de Ecoturismo. } \\
\text { - Incorporação dos princípios de descentralização governamental no turismo } \\
\text { por meio do Programa Nacional de Municipalização do Turismo (PNMT). }\end{array}$ \\
\hline $1996-2002$ & $\begin{array}{l}\text { Ministério do Esporte e Turismo. } \\
\text { - Apresentação de nova Política Nacional de Turismo para o período de 1996- } \\
1999 \text {, contendo dez objetivos estratégicos, entre os quais destacam-se a } \\
\text { descentralização, a 'conscientização' e articulação intra e extragovernamental. } \\
\text { - Instalaçãa dos comitês Visit Brazil, maiores investimentos em marketing e } \\
\text { divulgação no exterior, bem como promoção da pesca esportiva e do } \\
\text { ecoturismo. } \\
\text { - Flexibilização da legislação (resultando na queda das tarifas aéreas e no } \\
\text { inicio de cruzeiros com navios de bandeira internacional pela costa brasileira). }\end{array}$ \\
\hline $2003-2005$ & $\begin{array}{l}\text { Ministério do Turismo } \\
\text { - Criação do Ministério do Turismo com incorporação da EMBRATUR e nova } \\
\text { organização administrativa do turismo em nível nacional: EMBRATUR } \\
\text { (promoçáo e marketing do produto turístico brasileiro), Secretaria Nacional de } \\
\text { Políticas de Turismo (planejamento e articulação) e Secretaria Nacional de } \\
\text { Desenvolvimento do Turismo (implantação de infra-estrutura turística). } \\
\text { - Criação do Conselho Nacional de Turismo e do Fórum Nacional de } \\
\text { Secretários de Estado do Turismo. } \\
\text { - Lançamento do Salão Brasileiro de Turismo. } \\
\text { - Assinatura dos primeiros convênios relacionados ao PRODETUR - Sul. }\end{array}$ \\
\hline
\end{tabular}

Fonte: Beni (2006, p.19). 
Ainda, com relação aos mecanismos de atuação do Governo no mercado turístico, Beni (2006, p.23) divide as políticas públicas de turismo no Brasil em quatro fases, que são respectivamente: a década de 1970, a década de 1980, a década de 1990 e o momento atual. No período anterior a 1966 já existiam algumas políticas públicas para o setor, mas, com exceção da COMBRATUR, todas as demais se restringiam a políticas com a intenção de classificar as empresas turísticas (agências de viagens, restaurantes turísticos, operadora de turismo, etc.). Não ocorrendo no período nenhuma política que discorresse sobre uma ação mais efetiva de planejamento de turismo no Brasil.

- Década de 1970: o grande marco deste período é a criação da EMBRATUR em 1966 e do Conselho Nacional de Turismo (CNTUR), que juntos formaram o Sistema Nacional de Turismo. Somando-se a estas ações Beni (2006, p.24) enfatiza a criação de fundos para o financiamento de projetos tais como o Fundo Geral de Turismo (FUNGETUR) ${ }^{7}$ em 1971, além do Fundo de Investimento do Nordeste (FINOR), Fundo de Investimento da Amazônia (FINAM) e do Fundo de Investimentos Setoriais (FISET) em 1977.

Cruz (2001, p.77) também destaca como marco a criação de uma política regional de reordenamento do território no Rio Grande do Norte. A primeira política de turismo de caráter regional foi o Projeto Parque das Dunas Via Costeira. Ele visava dotar a área localizada entre as praias de Ponta Negra e Areia Preta de infra-estrutura hoteleira. Para tanto, foi elaborado um projeto de urbanização deste trecho com a construção de uma rodovia que dá acesso as glebas, onde foram construídos os hotéis, os restaurantes, bares, campings. Além das glebas e da rodovia também estava presente no projeto várias 'áreas de preservação' e a criação de um parque no local das dunas;

- Década de 1980: as preocupações com o meio ambiente entram em pauta, resultando na elaboração da Política Nacional do Meio Ambiente em conjunto com o Sistema Nacional do Meio Ambiente (SINAMA) e o cadastro de defesa ambiental, que acabam por influenciar a EMBRATUR a pensar num turismo com sustentabilidade ambiental e social.

\footnotetext{
${ }^{7}$ Segundo Cruz (2001, p.68) o "FUNGETUR destinava-se a fomentar e prover recursos para o financiamento de obras, serviços e atividades turísticas consideradas de interesse para o desenvolvimento do turismo nacional".
} 
A centralização política da atividade (nas figuras da EMBRATUR, CNTUR e Ministério da Indústria e Comércio) é vista como a melhor forma de promover o turismo.

- Década de 1990: dois programas se destacam no período o PRODETUR e o Programa Nacional de Municipalização do Turismo (PNMT).

O primeiro é uma política territorial composta pelos seguintes programas: PRODETUR/ NE; PROECOTUR (compreendendo as regiões da Amazônia Legal, Centro-Oeste e Pantanal Matogrossense); PRODETUR Sul e PRODETUR Sudeste.

Já o segundo tinha como objetivo conceder aos municípios brasileiros, considerados de potencial turístico, a faculdade de reger as ações em prol do turismo do modo como lhes fosse conveniente. O PNMT marca a extrema mudança de discurso entre políticas altamente centralizadoras para iniciativas mais voltadas a um empoderamento local (desenvolvimento local) ${ }^{8}$.

- Momento atual: começa com a criação do Ministério do Turismo (MTUR) em 2003. Sua criação gera uma redefinição das atribuições cabidas a EMBRATUR que passa a se encarregar exclusivamente da promoção do país no exterior "e a centralizar a elaboração de estudos e pesquisas para orientar os processos de tomada de decisão, avaliar o impacto do turismo na economia nacional e formatar novos produtos e roteiros turísticos" (BENI, 2006, p.29).

Cabendo, deste modo, ao MTUR e as Secretarias Nacionais de Políticas Públicas do Turismo e de Programas de Desenvolvimento do Turismo, o planejamento do turismo assim como seu marketing interno.

Um outro acontecimento de destaque no período é a elaboração do Programa Nacional de Regionalização do Turismo - Roteiros do Brasil (PRT - Roteiros do Brasil) que substitui o PNMT. Segundo o MTUR o PRT - Roteiros do Brasil: “é um modelo de gestão descentralizada, coordenada e integrada, com base nos princípios da flexibilidade, articulação, mobilização, cooperação intersetorial e interinstitucional e na sinergia de decisões". (Site do PRT - Roteiros do Brasil: http://www.turismo.gov.br/regionalizacao/).

\footnotetext{
${ }^{8}$ Endres (2002, p.72) contesta este programa como uma forma de empoderamento local, afirmando que o modelo era imposto a comunidade, sem que ela podesse argumentar ou criar uma metodologia que fosse adequada.
} 


\section{3 - PRODETUR/ NE}

O modelo de desenvolvimento adotado pelo Caribe, em especial por Cancun, baseado na combinação de atrativos naturais (leia-se praias) com megaempreendimentos de caráter hoteleiro (em especial resorts e hotéis de luxo) obteve grande 'sucesso' no que se refere a entrada de divisas em pequenos países do Caribe, representando inclusive para algumas ilhas a principal atividade produtiva da região.

Estes resultados 'positivos' acabaram por influenciar outros países a investirem no turismo adotando modelos de desenvolvimento turísticos semelhantes aos desenvolvidos no Caribe. O Brasil foi um destes países. No Brasil, o Nordeste, que era visto por muitos como o Caribe brasileiro, acabou por ser a região onde este modelo foi adotado primeiramente pela maioria dos seus Estados.

Na década de 1970 o Estado do Rio Grande do Norte criou o Projeto Parque das Dunas Via Costeira, no litoral sul do RN, mais precisamente entre as praias de Ponta Negra e Areia Preta. O projeto consistia na criação de áreas reservadas ao lazer, com este objetivo, foi construída uma rodovia ligando estas praias, que até aquele momento eram quase desertas, à região central de Natal e às principais rodovias dos Estados vizinhos. Também foi instalada uma rede elétrica no local. Toda área foi loteada sendo delimitada aonde se estabeleceria cada tipo de empreendimento. A ênfase maior do projeto era no estímulo a construção de infra-estrutura hoteleira, sendo concedidos incentivos fiscais diversos aos empresários que decidissem construir seus hotéis no local. Além do mais, o preço dos lotes (ou glebas) era ínfimo.

O Governo, em seu projeto inicial, também reservava áreas para a construção de restaurantes/ bares e trechos de preservação ambiental. Inclusive uma das primeiras ações do projeto foi a criação do 'Parque das Dunas' com o intuito de preservar parte do litoral onde estão presente as dunas. O discurso do poder público é que era melhor ocupar naquele momento o litoral de forma ordenada do que abandoná-lo e deixar que ele fosse ocupado no futuro de forma desordenada e caótica por outros. Apesar de utilizar um discurso preservacionista o que se viu na prática é que em parte da área onde deveria se localizar o Parque das Dunas a rodovia foi construída, além disso, a maioria das áreas de preservação foram ocupadas por hotéis, em alguns casos de forma caótica.

O projeto não foi seguido como previsto primeiramente, isso porque contava com a construção de alguns hotéis de luxo e resorts, mas acabou por comportar empreendimentos hoteleiros de médio porte. Atualmente o 'Parque das Dunas Via 
Costeira' é amplamente criticado por estudiosos do turismo devido à quantidade de impactos trazidos e até mesmo por este não ser considerado o modelo ideal de desenvolvimento do turismo, mas na época o projeto foi considerado um sucesso já que representou a entrada definitiva da cidade de Natal no ranking das cidades mais turísticas do Nordeste.

Na década de 1980 o Estado da Paraíba também optou por uma modelo de desenvolvimento turístico semelhante ao de Cancun e ao que estava sendo implementado em Natal, dessa forma, foi criado o Projeto do Cabo Branco na cidade de João Pessoa na praia do Cabo Branco. Assim como em Natal, o megaprojeto da Paraíba também enfatizava a atração de empreendimentos hoteleiros com a concessão de uma série de incentivos fiscais. Além dos hotéis também foi reservada uma área para a construção de um parque temático, centro de convenções, dois campos de golfe e lojas.

Na Figura 04 podemos observar a área que foi escolhida para a construção do projeto (indicado pelas setas vermelhas), compreende as margens da rodovia, toda a área verde formada por resquícios da Mata Atlântica.

Figura 04: Vista Aérea do Final do Bairro do Cabo Branco

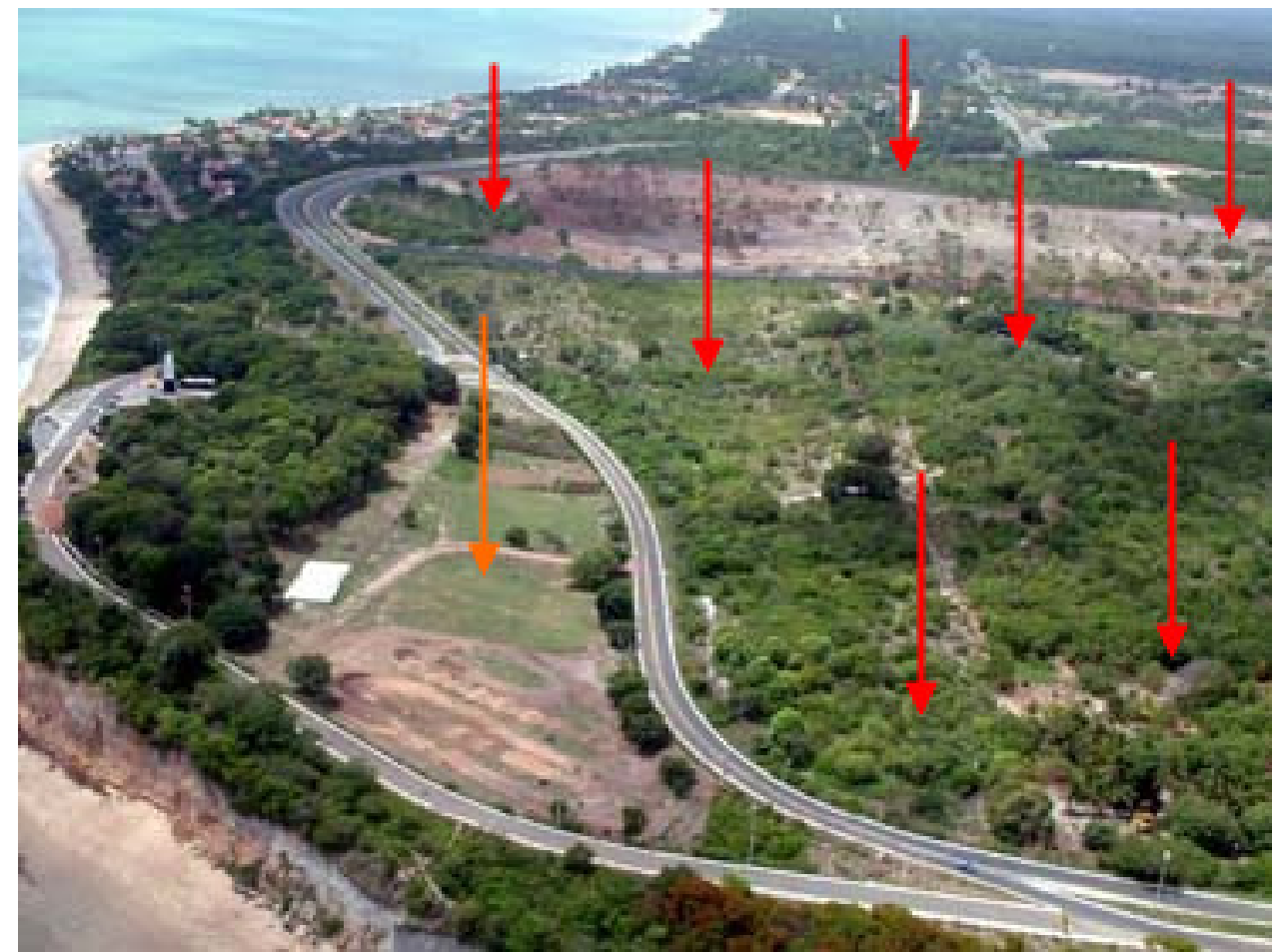

Fonte: Adaptado de Ricardo Paulo - CD turístico: Guia turístico da cidade de João Pessoa (2001).

O projeto do Cabo Branco não foi implementado. Apenas algumas poucas ações pontuais como a construção da rodovia e do portal de entrada foram efetuadas. A principal razão para o insucesso do projeto foi o grande impacto ecológico que poderia 
causar à região. Além de desmatar a pouca área restante de Mata Atlântica, a região é considerada ecologicamente frágil, já que devido ao desmatamento a falésia do Cabo Branco se encontra em acelerado processo de erosão.

Devido à fragilidade local, em 2003 a secretaria municipal de turismo proibiu o tráfego de grandes veículos (ônibus e caminhões) no trecho da rodovia mais próxima a falésia. ${ }^{9}$ Além dos impactos ambientais a falta de infra-estrutura básica/ urbana que existia no local também constituiu empecilho a sua efetivação. Outro fator determinante foram os contraditórios interesses políticos que existiam no Estado.

Poucos anos após a elaboração do projeto na Paraíba, os estados de Alagoas e Pernambuco também criaram um projeto que compreendia o litoral sul de Pernambuco e litoral norte de Alagoas, este foi denominado de Projeto Costa Dourada. Da mesma forma que os demais, o projeto também previa a criação de infra-estrutura hoteleira de alto padrão. A diferença com relação aos demais projetos é a extensão do Costa Dourada que é amplamente superior aos outros, incluindo inclusive a criação de um Centro Turístico ${ }^{10}$ denominado Guadalupe. Pela magnitude do projeto e a escassez de infra-estrutura na região, o projeto acabou por ter poucas ações efetivadas de fato como a construção de alguns hotéis de luxo na região.

Já na década de 1990, foi elaborado o Projeto Linha Verde no litoral baiano, o enfoque principal era a construção de uma rodovia ligando todo o litoral baiano e, em todo o seu entorno, de modo mais espaçado que os projetos anteriores, a construção de equipamentos hoteleiros. O ponto alto da efetivação do projeto foi a construção do resort Costa do Sauípe.

Dos quatro megaprojetos apenas dois: Parque das Dunas Via Costa e a Linha Verde realizaram ações mais consistentes, que de forma mais ampla influenciaram a atividade turística em seus Estados, no que se refere ao fornecimento de uma infraestrutura de acesso e hoteleira.

Apesar de não ter sido implantado como previsto o Projeto Costa Dourada representou um marco nas políticas públicas de turismo no Nordeste e no Brasil, já que no período de tentativa de efetivação, o então presidente da república, e um dos maiores

\footnotetext{
${ }^{9}$ Apesar da fragilidade local, a região continua sendo alvo de projetos com o intuito de atrair turistas, atualmente está sendo construído no local (apontado pela seta laranja) uma estação de ciência, cultura e arte, projeto criado por Oscar Niemeyer. E em parte da região apontada pelas setas vermelhas pretendesse construir um centro de convenções, o projeto já está em fase de licitação.

${ }^{10}$ Segundo Boullón (2002, p.80) centro turístico é todo conglomerado urbano que conta em seu próprio território ou dentro de seu raio de influência com atrativos turísticos de tipo e hierarquia suficientes para motivar uma viagem turística.
} 
incentivadores do projeto, Collor de Mello, em conjunto com a SUDENE e o Instituto Brasileiro de Turismo (EMBRATUR), perceberam que um dos maiores entraves para sua implementação era a falta de infra-estrutura (tanto de acesso, como básica urbana), tendo, deste modo, a idéia de criar um projeto que dotasse de infra-estrutura as regiões nordestinas consideradas de vocação turística (ler-se regiões litorâneas), assim nasce o PRODETUR/NE através da Portaria Conjunta $n^{0} 1$, de 29 de novembro de 1991. Por razões de cunho político o PRODETUR/ NE não se restringiu apenas aos Estados que haviam elaborado os megaprojetos turísticos, mas sim a toda área de atuação da SUDENE, que são os nove Estados nordestinos: Pernambuco, Paraíba, Piauí, Alagoas, Bahia, Ceará, Maranhão, Sergipe e Rio Grande do Norte. E em sua segunda fase, a região Norte do Estado de Minas Gerais e, o Espírito Santo.

O PRODETUR/NE é um programa de crédito para o setor público (Estados e Municípios) que foi concebido tanto para criar condições favoráveis à expansão e melhoria da qualidade da atividade turística na Região Nordeste, quanto para melhorar a qualidade de vida das populações residentes nas áreas beneficiadas. Fonte: Site do Banco do Nordeste

(http://www.bnb.gov.br/content/aplicacao/PRODETUR/Apresentacao).

Em sua segunda fase, o programa em conjunto com os governos estaduais identificou as principais áreas de interesse turístico e deu iniciou a formação de pólos turísticos. Ao total foram formados 16 pólos turísticos.

Figura 05: Pólos de Turismo - PRODETUR Fase II

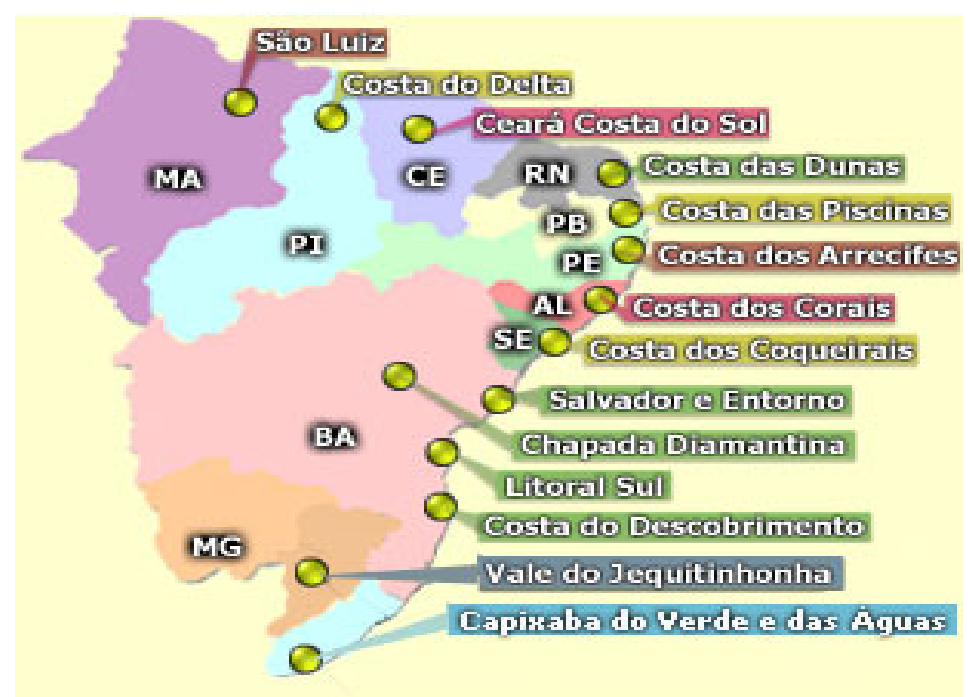

Fonte: (http://www.bnb.gov.br/content/aplicacao/PRODETUR/Polos/gerados).

Os pólos foram criados com base nos investimentos realizados na primeira fase do programa. Assim as regiões que após serem contempladas na primeira fase e que apresentaram resultados mais expressivos com relação à disponibilidade de infra- 
estrutura e fluxo de turistas formaram os pólos na fase seguinte. Adicionando-se a estes o Norte de Minas Gerais e o Espírito Santo que não integraram a primeira fase do programa.

\begin{abstract}
O PRODETUR/ NE foi estruturado com recursos externos, provenientes em sua quase totalidade do Banco Interamericano de Desenvolvimento (BID) e do Banco Mundial (BIRD), tornando-se o programa por meio do qual o governo interviu na região através de ações de ordenamento e de alavancagem do processo de desenvolvimento turístico no território, notadamente com a implantação de infra-estrutura básica (transporte, saneamento, energia), instalação de equipamentos urbanos e oferta de serviços públicos em espaços considerados com vocação turística e definição para a expansão turística. Os recursos e investimentos destinados a esse programa foram concentradamente aplicados na construção e operacionalização dos aeroportos da região. (BENI, 2006, p.27).
\end{abstract}

O PRODETUR/ NE foi criado claramente com a intenção de tornar possível a efetivação de megaempreendimentos hoteleiros no Nordeste, inclusive após a sua criação em 1992 passou a conceder crédito para que alguns Estados, a exemplo da Bahia, pudessem dar continuidade a seus megaprojetos.

Desta forma, alguns autores como Coriolano (2007, p.68) e Aguiar (2007, p.109) criticam o programa como um instrumento para a implementação de um modelo de ‘desenvolvimento' turístico já ultrapassado (modelo Cancun) que traz mais malefícios do que benefícios à comunidade local e ao meio ambiente. De acordo com Aguiar (2007: 109) o PRODETUR/NE I constitui numa forma de facilitação do processo de apropriação das praias nordestinas pelo turismo, tirando das mãos da população local seu próprio espaço, além disso, tenta "sub-repticiamente privatizar as melhores e mais belas praias".

Sob está visão o PRODETUR serviria como um instrumento para o desenvolvimento de um turismo insustentável em todos os campos (social, cultural, econômico e ecológico), contribuindo inclusive para a 'privatização' mascarada de praias no Nordeste. Diferente da maioria das outras políticas de turismo, o PRODETUR se concentra na liberação de recursos para o atendimento de infra-estrutura básica/ urbana das cidades, o que faz Cruz (2000, p.10) afirmar que o "PRODETUR faz às vezes de uma política urbana”. 


\section{O ESTADO DA PARAIIBA}

\section{1 - Informações Gerais}

O Estado da Paraíba, segundo os dados do Instituto Brasileiro de Geografia e Estatística (IBGE) possuía em 2004 uma população de 3.568 .350 habitantes. A estimativa da população para o ano seguinte era de 3.595.886. Sua área total é de $56.439,838 \mathrm{~km}^{2}$, sendo constituída por 223 municípios. A população paraibana no ano de 2005 correspondia a aproximadamente $1,95 \%$ da população brasileira, sua extensão territorial corresponde a $0,66 \%$ (aproximadamente) com relação ao território nacional.

Tabela 03: Serviços básicos de Infra-estrutura

\begin{tabular}{|c|c|c|c|c|c|c|}
\hline Estado & $\begin{array}{c}\text { Percentual } \\
\text { de pessoas } \\
\text { que vivem } \\
\text { em } \\
\text { domicílios } \\
\text { com água } \\
\text { encanada, } \\
\text { (2005). }\end{array}$ & $\begin{array}{c}\text { Percentual } \\
\text { de pessoas } \\
\text { que vivem } \\
\text { em } \\
\text { domicílios } \\
\text { com água } \\
\text { encanada, } \\
\text { (2000). }\end{array}$ & $\begin{array}{l}\text { Percentual de } \\
\text { pessoas que } \\
\text { vivem em } \\
\text { domicílios } \\
\text { com energia } \\
\text { elétrica, } \\
(2005) .\end{array}$ & $\begin{array}{l}\text { Percentual de } \\
\text { pessoas que } \\
\text { vivem em } \\
\text { domicílios } \\
\text { com energia } \\
\text { elétrica, } \\
(2000) .\end{array}$ & $\begin{array}{l}\text { Percentual de } \\
\text { pessoas que } \\
\text { vivem em } \\
\text { domicílios } \\
\text { urbanos com } \\
\text { serviço de } \\
\text { coleta de lixo, } \\
(2005) \\
\end{array}$ & \begin{tabular}{|c|} 
Percentual de \\
pessoas que \\
vivem em \\
domicílios \\
urbanos com \\
serviço de \\
coleta de lixo, \\
$(2000)$ \\
\end{tabular} \\
\hline Brasil & - & 80,75 & - & 93,48 & - & 91,16 \\
\hline Alagoas & $64,1 \%$ & $62,0 \%$ & $96,3 \%$ & $89,8 \%$ & $71,8 \%$ & $91,0 \%$ \\
\hline Bahia & $75,1 \%$ & $60,2 \%$ & $91,2 \%$ & $80,9 \%$ & $71,4 \%$ & $85,2 \%$ \\
\hline Ceará & $74,0 \%$ & $59,5 \%$ & $95,6 \%$ & $88,3 \%$ & $72,2 \%$ & $81,7 \%$ \\
\hline Maranhão & $61,3 \%$ & $32,8 \%$ & $84,0 \%$ & $78,7 \%$ & $59,6 \%$ & $53,2 \%$ \\
\hline Paraíba & $78,2 \%$ & $66,5 \%$ & $98,0 \%$ & $94,4 \%$ & $77,4 \%$ & $87,9 \%$ \\
\hline Pernambuco & $75,1 \%$ & $67,2 \%$ & $98,0 \%$ & $95,4 \%$ & $78,6 \%$ & $84,6 \%$ \\
\hline Piauí & $67,2 \%$ & $48,1 \%$ & $88,2 \%$ & $74,6 \%$ & $51,1 \%$ & $66,0 \%$ \\
\hline $\begin{array}{l}\text { Rio Grande } \\
\text { do Norte }\end{array}$ & $87,8 \%$ & $67,6 \%$ & $97,5 \%$ & $94,3 \%$ & $83,5 \%$ & $92,1 \%$ \\
\hline Sergipe & $88,0 \%$ & $71,5 \%$ & $96,8 \%$ & $91,8 \%$ & $81,8 \%$ & $89,6 \%$ \\
\hline São Paulo & $96,2 \%$ & $97,8 \%$ & $99,8 \%$ & $99,6 \%$ & $98,4 \%$ & $98,8 \%$ \\
\hline
\end{tabular}

Fonte: Atlas do Desenvolvimento Humano no Brasil (2000); IBGE/ PNAD (2005).

Como podemos observar a Paraíba em comparação com os demais Estados nordestinos possui indicadores dentro da média, sendo destacado apenas o fornecimento de energia elétrica no ano de 2005, 98,0\%, que em conjunto com Pernambuco representou o melhor percentual do Nordeste neste quesito. Mas em comparação com São Paulo, podemos perceber que todos os indicadores dos Estados nordestinos são inferiores aos deste Estado, sendo destacada a enorme diferença no quesito água 
encanada no ano de 2000, apesar desta diferença ter caído no ano de 2005 as disparidades ainda são enormes.

O processo de formação econômica e social da Paraíba é resumido por Wills Leal (2001, p.23) da seguinte forma:

Os canaviais, que se espalham pela Zona da Mata e dependem de mão-deobra de escravos africanos, atraem o interesse dos holandeses no século XVII. O agreste e todo o sertão são ocupados por fazendas de gado. No século XVIII, a mineração de ouro e diamante no centro-sul acentua o declínio da economia canavieira. No século XIX, depois de se envolver nas lutas de independência, na Revolta Pernambucana de 1817 e na Confederação do Equador em 1824, a Paraíba atravessa etapa de relativa estabilidade política. Mas o empobrecimento da região afeta a província. Durante a República Velha (1889-1930), a agricultura permanece estagnada e as oligarquias rurais mantêm amplo poder político. Na década de 60 , os investimentos, em grande parte promovidos pela Sudene, pouco ajudam na industrialização do estado.

Ainda com relação à formação econômica do território paraibano, Leal (2001, p.43) destaca a influência que os Estados do Rio Grande do Norte, Ceará e, em especial, Pernambuco, tiveram sobre a Paraíba.

O processo de urbanização da cidade se deu, no final do século passado, muito lentamente. A Parahyba continuou vivendo permanentemente asfixiada por Pernambuco, em todos os sentidos, como se verificou, aliás, desde os primeiros dias de fundação da Capitania. Essa subordinação era tão evidente, que as Associações Comerciais de Pernambuco e do Ceará chegaram, certa vez, a protestar contra um plano ferroviário para a Paraíba, por entenderem, segundo nota oficial que divulgaram, que 'tal traçado ferroviário nos prejudica', isto é, não atendiam aos seus interesses, e sim aos nossos, aos da Paraíba. [...] Sem uma rodovia que nos beneficiasse, sem porto e com nosso comércio em total dependência de Pernambuco e Rio Grande do Norte, a economia paraibana ficava em permanente situação de miséria. Pouco poderia esperar do governo local, pois os seus limitados recursos normalmente eram canalizados para combater as permanentes secas e surtos de doenças epidêmicas que grassavam com regularidade. (op. cit.)

Atualmente a economia da Paraíba é baseada principalmente na agricultura (em especial no cultivo da cana-de-açúcar, abacaxi, mandioca, milho, feijão, banana e algodão); pecuária (criação de bois, suínos, ovinos e eqüinos); e indústria (artigos de couro, além de produtos industrializados alimentícios e têxteis, açúcar e álcool). Existe no Estado um pólo calçadista, concentrado principalmente nas cidades de João Pessoa, Campina Grande e Patos, com 73 empresas fabricantes de artigos de couro, e mais de 500 micro-indústrias do setor informal, distribuídas nas diversas cidades pólos do Estado.

A pirâmide etária da população paraibana, conforme podemos observar no gráfico abaixo, é formada predominantemente de jovens na faixa etária de 25 a 39 anos. 
Gráfico 01: Faixa Etária da População Paraibana - 2005

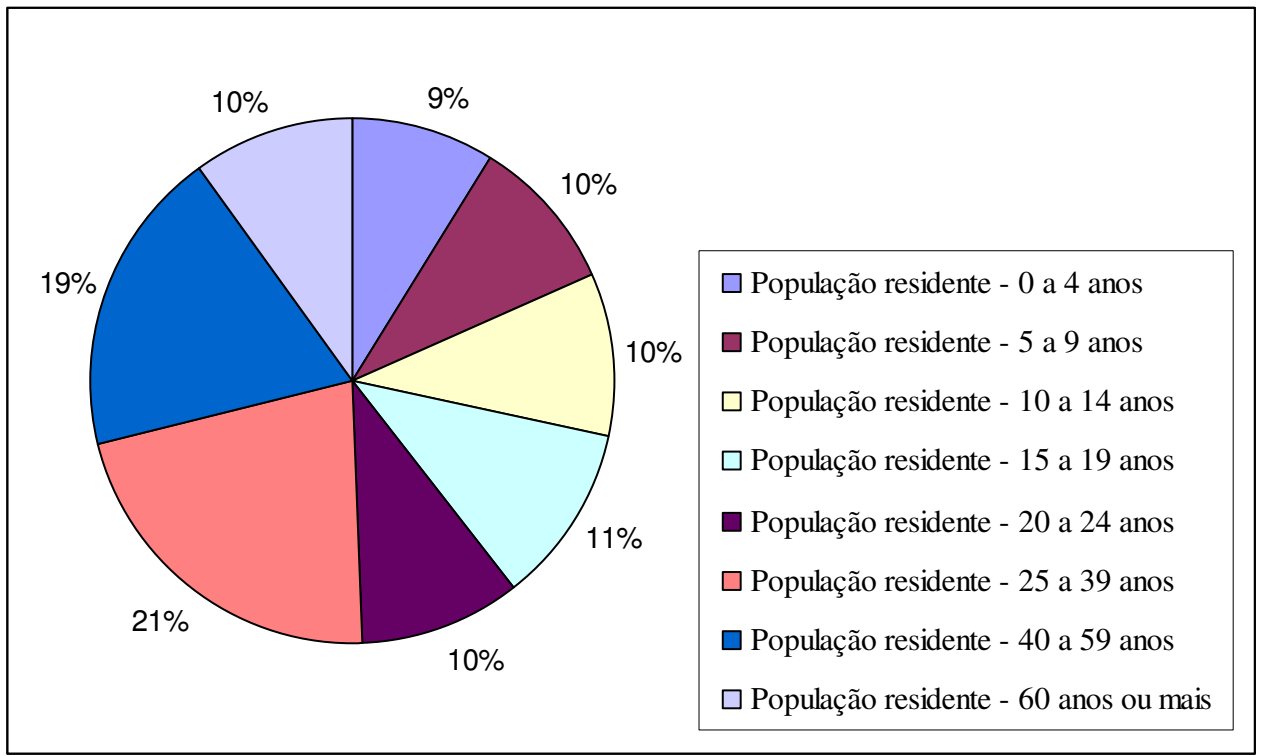

Fonte: Baseado em dados da Pesquisa Nacional por Amostra de Domicílios - 2005

Metade da população paraibana (50\%) tem idade a partir de 25 anos, sendo mais representantes os grupos de 25 a 39 anos e de 40 a 59 anos com $21 \%$ e $19 \%$ respectivamente. Apesar de ser bastante representativa a parcela da população a partir dos 25 anos, a escolarização da população no geral, em especial a partir dos 18 anos é baixa, em comparação com anos anteriores.

Conforme podemos observar no gráfico abaixo apenas 35,9\%, segundo as pesquisas do IBGE/ PNAD 2005, dos jovens a partir dos 18 anos dão prosseguimento aos seus estudos.

Gráfico 02: Taxa de Escolarização da População Paraibana segundo Faixa Etária - 2005

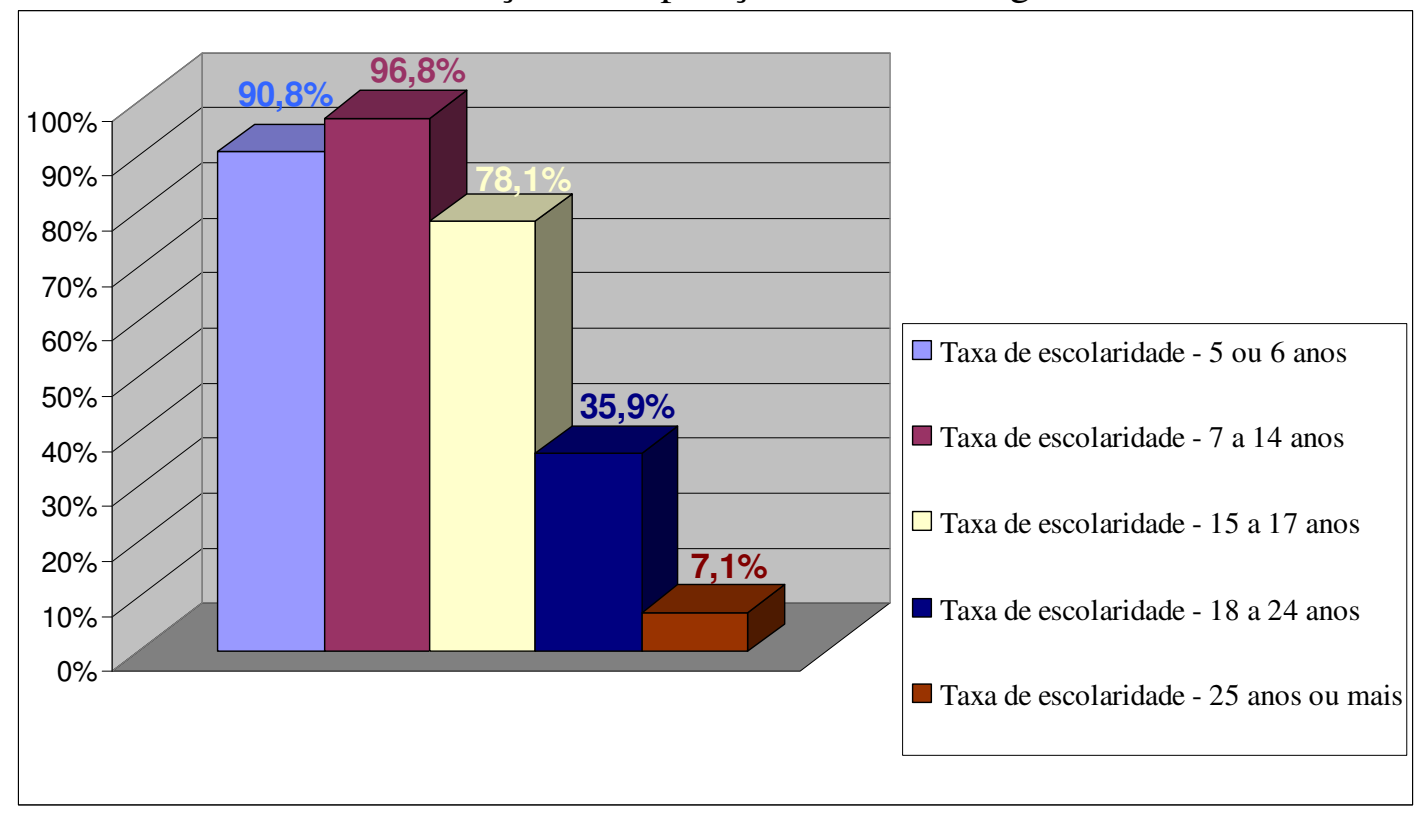

Fonte: Baseado em dados da Pesquisa Nacional por Amostra de Domicílios - 2005. 
Gráfico 03: Desemprego na Paraíba

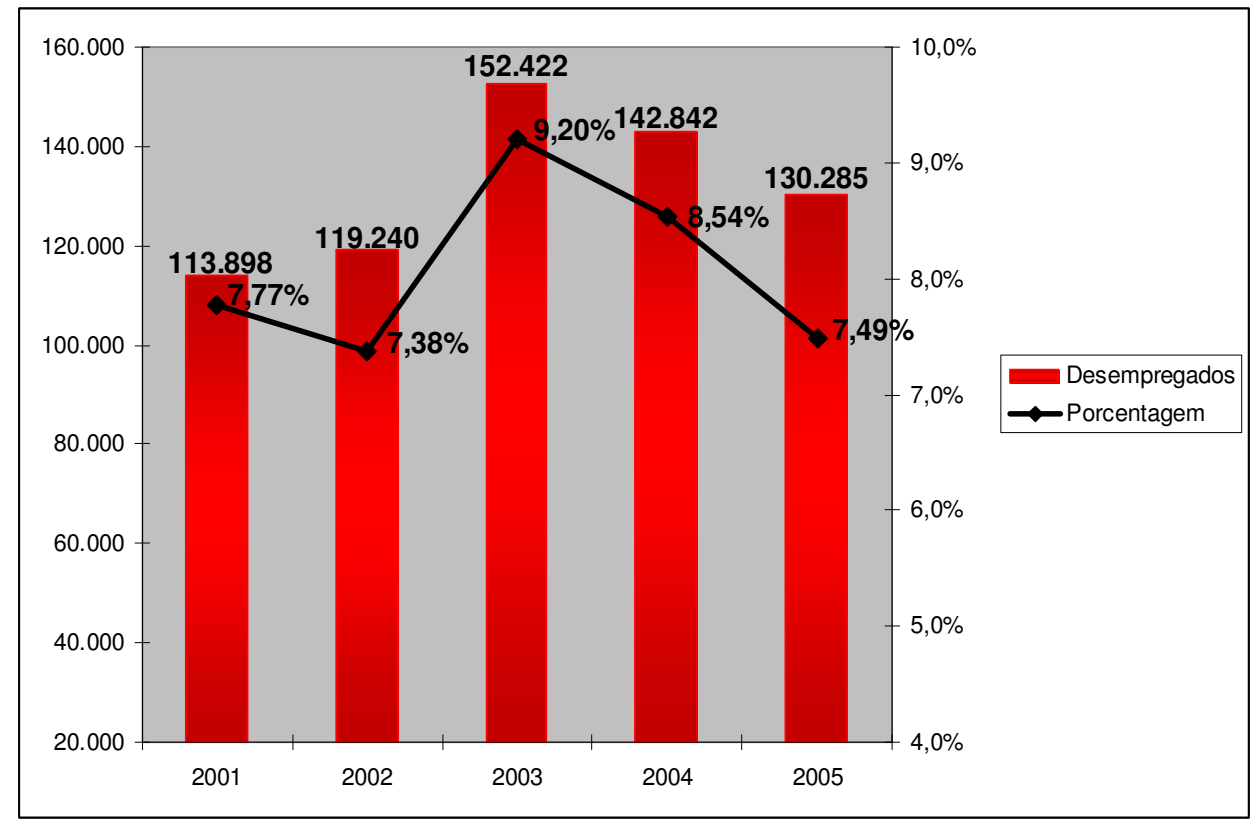

Fonte: Baseado em dados do Site do DataSUS.

Segundo dados do IBGE, a taxa de desemprego média brasileira em 2001 era de 6,2\%, enquanto que em 2002 foi de 7,1\%. Assim comparando estes dados com os apresentados pela Paraíba, o índice de desemprego, ao menos no que se refere aos anos em questão, foi maior do que a média nacional.

Quadro 03: Quadro comparativo do Índice de Gini

\begin{tabular}{|l|c|}
\hline \multicolumn{1}{|c|}{ Local } & \multicolumn{2}{c|}{ Índice de Gini (2000) } \\
\hline Brasil - Média & 0,616 \\
\hline Região Nordeste - Média & 0,665 \\
\hline Paraíba & $\mathbf{0 , 6 4 6}$ \\
\hline & \\
\hline São Paulo & 0,590 \\
\hline
\end{tabular}

Fonte: Atlas IDH (2000).

Como observarmos o índice de Gini $^{11}$ da Paraíba é menor do que a média nordestina, no entanto, é maior do que a média brasileira, e se comparado ao Estado de São Paulo, é bastante superior.

A seguir poderemos observar alguns dados sócio-econômicos das quatro messoregiões (Sertão, Borborema, Agreste e Zona da Mata) do Estado, em separado, com o intuito de percebemos as divergências sócio-econômicas que ocorrem dentro do mesmo Estado.

\footnotetext{
${ }^{11}$ Segundo o PNUD (site http://www.pnud.org.br/popup/pop.php?id_pop=97) o Índice de Gini pode ser conceituado como indicador que "mede o grau de desigualdade existente na distribuição de indivíduos segundo a renda domiciliar per capita. Seu valor varia de 0 , quando não há desigualdade (a renda de todos os indivíduos tem o mesmo valor), a 1 , quando a desigualdade é máxima (apenas um indivíduo detém toda a renda da sociedade e a renda de todos os outros indivíduos é nula)".
} 


\subsection{1 - Mesorregião do Sertão}

O Sertão é formado por oito microrregiões que são: Cajazeiras, Catolé do Rocha, Itaporanga, Patos, Piancó, Serra do Teixeira e Sousa. Estas microrregiões somadas representam uma área total de 22.720,482 $\mathrm{km}^{2}$ com uma população de 831.031 habitantes, segundo dados do IBGE de 2005. O clima é predominantemente quente e úmido, com algumas microrregiões com clima semi-árido.

Quadro 04: Alguns Indicadores do Sertão Paraibano x Brasil

\begin{tabular}{|l|r|}
\hline PIB total (2003) & $\mathrm{R} \$ 2.013 .915 .968,00$ \\
\hline PIB per capita (2003) & $\mathrm{R} \$ 2.447,28$ \\
\hline PIB per capita (2003) - Brasil & $\mathrm{R} \$ 8.694,00$ \\
\hline IDH (2000) & 0,622 \\
\hline IDH (2000) - Brasil & 0,766 \\
\hline \% População/ Paraíba (2005) & $23 \%$ \\
\hline \% de Área Ocupada/ Paraíba & $40,2 \%$ \\
\hline Densidade Demográfica & 36,6 hab./km² \\
\hline
\end{tabular}

Fonte: Site do IBGE; PNAD; IBGE Cidades; Atlas IDH 2000.

Figura 06: Mapa das Microrregiões do Sertão Paraibano

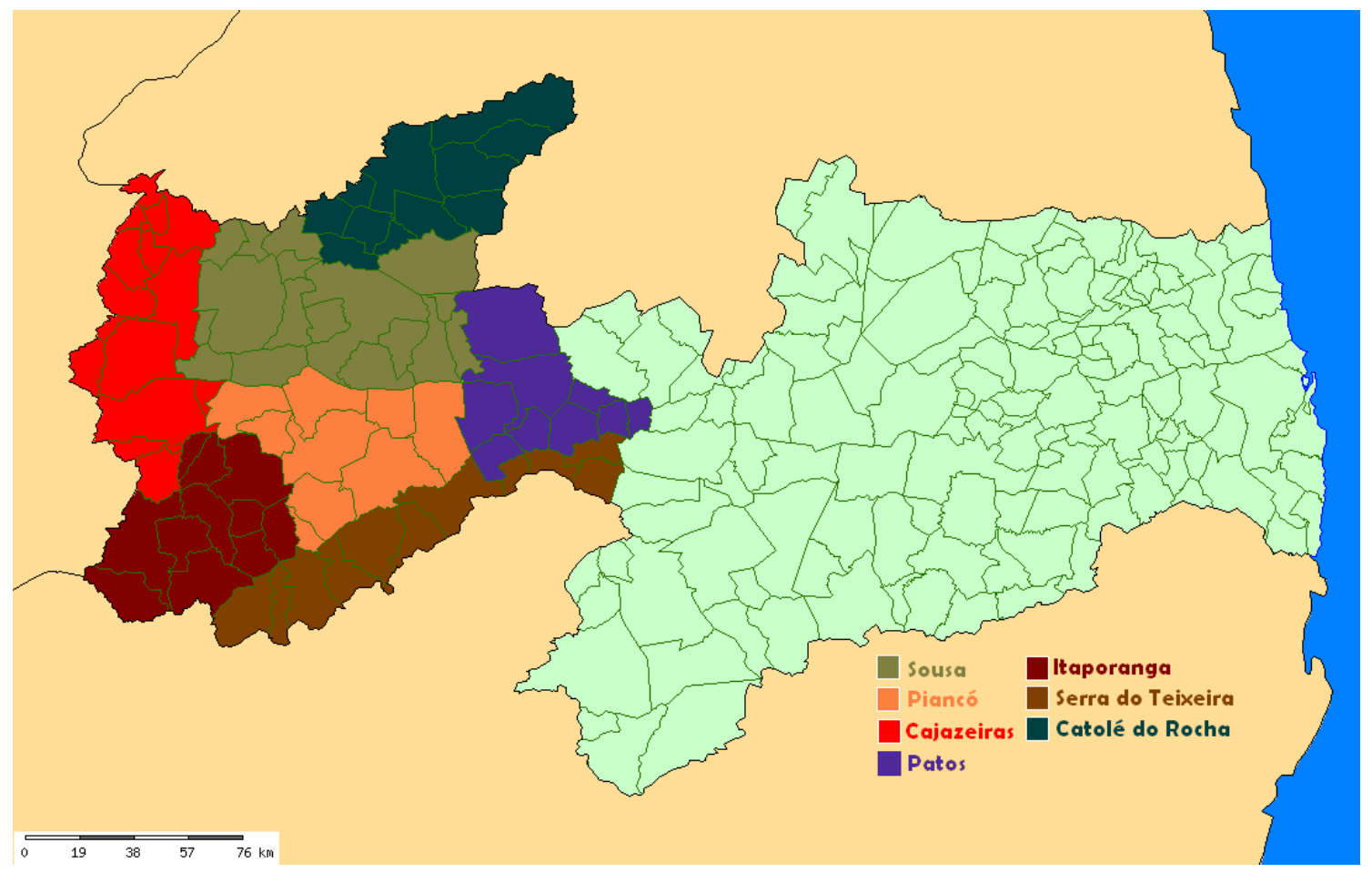

Fonte: Adaptado do http://geo.aesa.pb.gov.br/ 


\subsection{2 - Mesorregião da Borborema}

A mesorregião da Borborema é constituída por 04 microrregiões que são: Cariri Oriental, Cariri Ocidental, Seridó Oriental e Seridó Ocidental.

De acordo com o IBGE a área total é de $15.572,891 \mathrm{~km}^{2}$ e sua população em 2005 era de 283.607 hab. O clima predominante é o quente e seco, e em algumas microrregiões semi-árido. O município de Cabaceiras, no Cariri Oriental, possui um dos menores índices pluviométricos de todo país. Conforme a tabela abaixo, também podemos perceber que a Borborema é a mesorregião mais carente do Estado.

Quadro 05: Alguns Indicadores da Borborema Paraibana x Brasil

\begin{tabular}{|l|r|}
\hline PIB total (2003) & $\mathrm{R} \$ 609.434 .048,00$ \\
\hline PIB per capita (2003) & $\mathrm{R} \$ 2.173,76$ \\
\hline PIB per capita (2003) - Brasil & $\mathrm{R} \$ 8.694,00$ \\
\hline IDH (2000) & 0,613 \\
\hline IDH (2000) - Brasil & 0,766 \\
\hline \% População/ Paraíba (2005) & $8 \%$ \\
\hline \% de Área Ocupada/ Paraíba & $27,6 \%$ \\
\hline Densidade Demográfica & $18,2 \mathrm{hab} . / \mathrm{km}^{2}$ \\
\hline
\end{tabular}

Fonte: Site do IBGE; PNAD; IBGE Cidades; Atlas IDH 2000.

Figura 07: Mapa das Microrregiões da Borborema

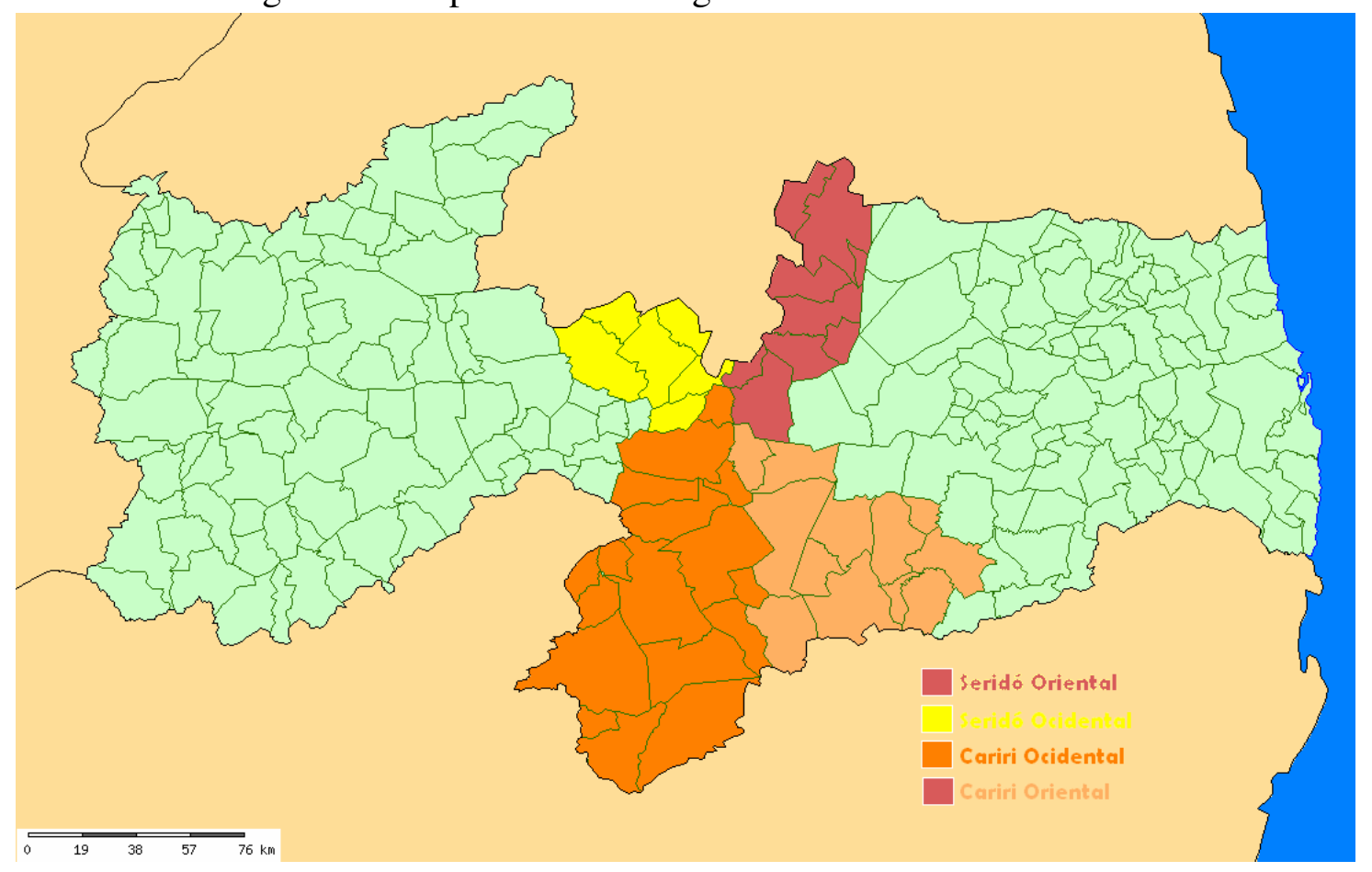

Fonte: Adaptado do http://geo.aesa.pb.gov.br/ 


\subsection{3 - Mesorregião do Agreste Paraibano}

Ela é formada por 08 microrregiões, que são: Brejo, Campina Grande, Curimataú Oriental, Curimataú Ocidental, Esperança, Guarabira, Itabaiana e Umbuzeiro.

Representando $12.914,069 \mathrm{~km}^{2}$ da área total, a sua população é de 1.180 .886 habitantes. O clima predominante é o tropical úmido, com chuvas de outono-inverno.

Quadro 06: Alguns Indicadores do Agreste Paraibano x Brasil

\begin{tabular}{|l|r|}
\hline PIB total (2003) & $\mathrm{R} \$ 3.657 .403 .690,00$ \\
\hline PIB per capita (2003) & $\mathrm{R} \$ 3.147,37$ \\
\hline PIB per capita (2003) - Brasil & $\mathrm{R} 8.694,00$ \\
\hline IDH (2000) & 0,631 \\
\hline IDH (2000) - Brasil & 0,766 \\
\hline \% População/ Paraíba (2005) & $32 \%$ \\
\hline \% de Área Ocupada/ Paraíba & $22,8 \%$ \\
\hline Densidade Demográfica & $91,4 \mathrm{hab} . / \mathrm{km}^{2}$ \\
\hline
\end{tabular}

Fonte: Site do IBGE; PNAD; IBGE Cidades; Atlas IDH (2000).

Figura 08: Mapa das Microrregiões do Agreste

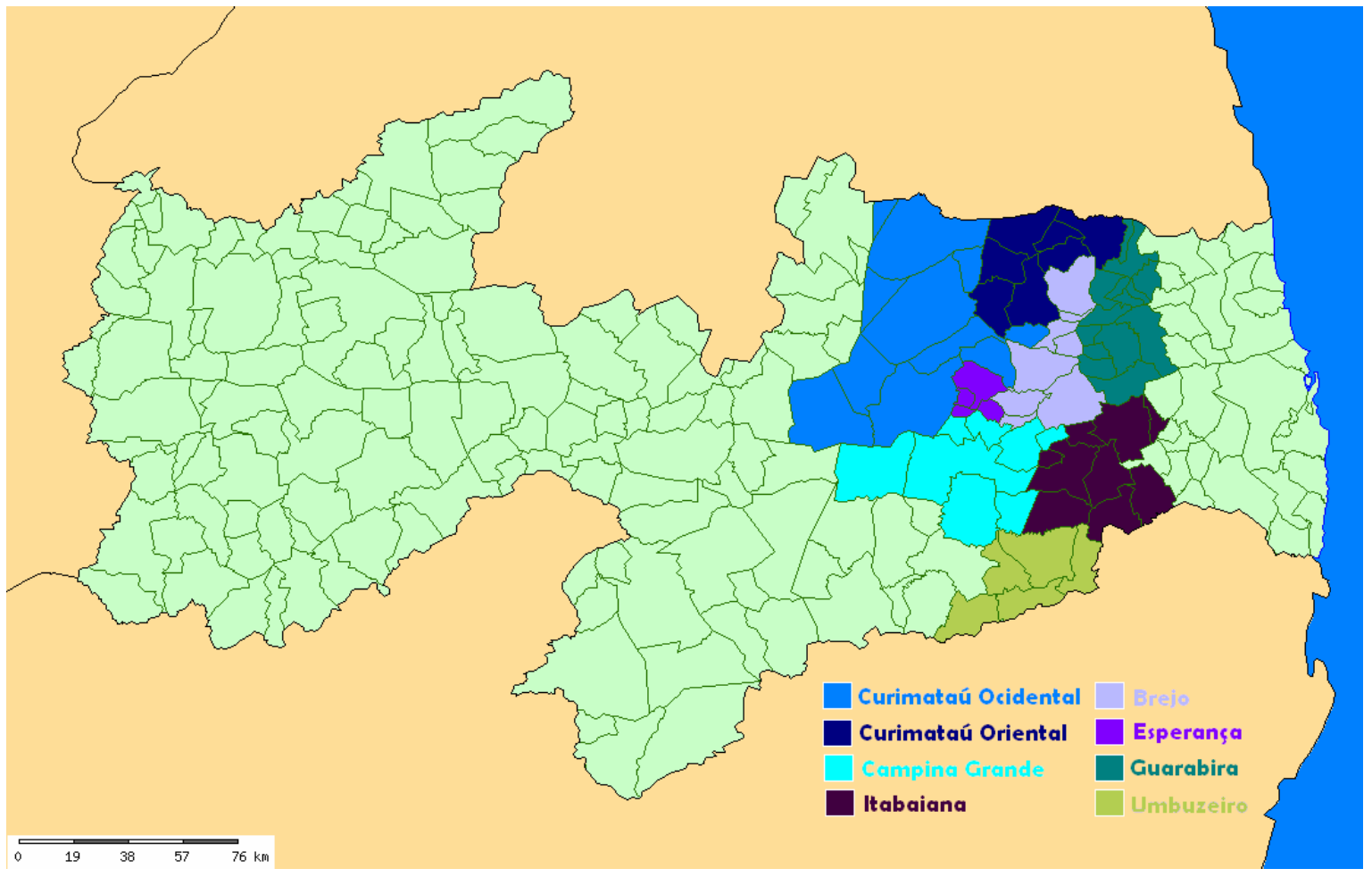

Fonte: Adaptado do http://geo.aesa.pb.gov.br/ 


\subsection{4 - Mesorregião da Zona da Mata}

Formada por quatro microrregiões, que são: João Pessoa, Litoral Norte, Sapé e Litoral Sul. Apresenta uma área total de 5.232,396 km², com a maior concentração população do Estado, 1.327.691 hab. Seu clima é predominantemente quente e úmido com chuvas de verão e outono.

Quadro 07: Alguns Indicadores da Zona da Mata Paraibana x Brasil

\begin{tabular}{|l|r|}
\hline PIB total (2003) & $\mathrm{R} \$ 7.430 .159 .786,00$ \\
\hline PIB per capita (2003) & $\mathrm{R} \$ 5.890,21$ \\
\hline PIB per capita (2003) - Brasil $\$ 8.694,00$ \\
\hline IDH (2000) & 0,703 \\
\hline IDH (2000) - Brasil & 0,766 \\
\hline \% População/ Paraíba (2005) & $37 \%$ \\
\hline \% de Área Ocupada/ Paraíba & $9,4 \%$ \\
\hline Densidade Demográfica & 253,7 hab./km² \\
\hline
\end{tabular}

Fonte: Site do IBGE; PNAD; IBGE Cidades; Atlas do IDH (2000).

Figura 09: Mapa das Microrregiões da Zona da Mata

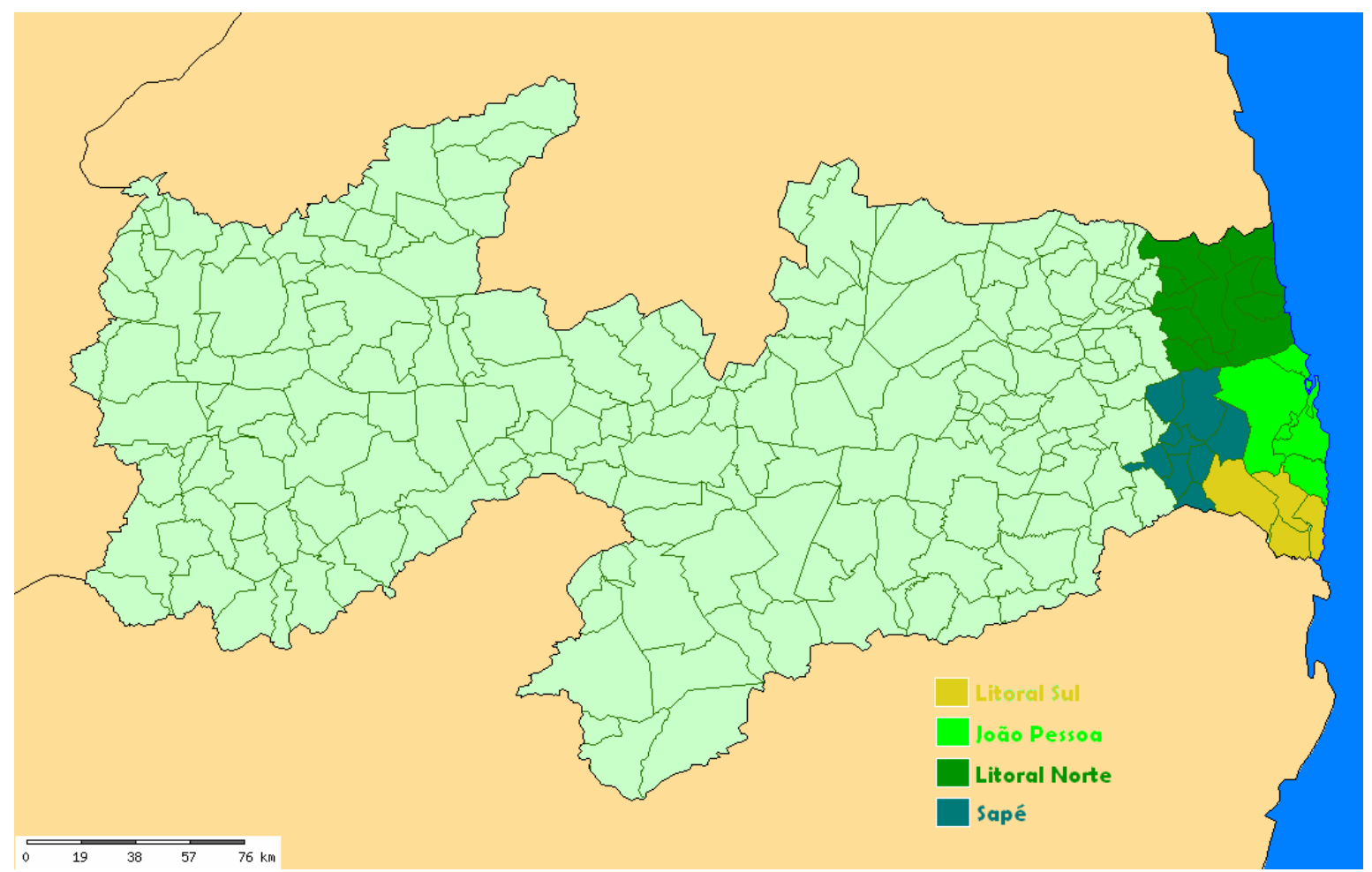

Fonte: Adaptado do http://geo.aesa.pb.gov.br/ 


\section{2 - Turismo na Paraíba}

O histórico evolutivo da atividade turística na Paraíba é estudado por Leal (2001) sob duas vertentes. Na primeira é realizada uma divisão entre as atividades 'paraturísticas' e o início do que se pode conceituar como turismo de fato. E em um segundo momento, o turismo é estudado de acordo com a implantação da infra-estrutura hoteleira no Estado.

O histórico do turismo paraibano para Leal (2001, p.20) tem início em 1585 (no ano de fundação da cidade de João Pessoa), quando chegam os primeiros militares, religiosos, comerciantes e artesões com a intenção de construir equipamentos e montar estruturas operacionais para a capital, sendo esta fase denominada por Leal (op. cit.) de fase embrionária do turismo caracterizando o que o autor denomina de paraturismo ${ }^{12}$. Após este período o turismo cresce constantemente no Estado, sofrendo, assim como em todo mundo, uma queda nos períodos da Primeira e Segunda Guerras Mundiais. A maturação total do turismo no Estado ocorre em 1971 quando é inaugurado o Hotel Tambaú.

As fases relacionadas à criação de infra-estrutura hoteleira são quatro: a primeira a partir de 1870 (quando casas começam a ser adaptadas para servirem de estalagem); a segunda tem início nos primeiros anos deste século e acaba em 1920, com a construção do novo Hotel Globo; a terceira, nos anos de 1930, com o funcionamento do 'Parayba Hotel'; e a última tem início em 1971 com a inauguração do Hotel Tambaú.

Nas instalações de hospedagem da primeira fase (estalagens, pensões), não havia qualquer serviço adicional de atendimento ao 'turista', a maioria das pensões/ estalagens da época não disponibilizavam nem mesmo condições higiênico sanitárias adequadas. Os visitantes do sexo masculino se banharam nos rios próximos as instalações de hospedagem e as mulheres utilizavam cuias nos quintais das hospedarias.

\footnotetext{
As precárias condições de hospedagem na cidade, no século passado, eram encontradas até mesmo em nossos locais mais nobres, como a própria sede do governo. Assim, para que o local tivesse adequadas condições para acomodar o Imperador, em 1859, o Palácio passou por uma total transformação. (LEAL, 2001, p.63).
}

\footnotetext{
${ }^{12}$ Lembrando que o que Leal (2001, p.20) denomina de paraturismo possui como único ponto comum ao turismo moderno o deslocamento, não possuindo as demais características próprias do turismo (temporalidade e objeto do turismo).
} 
Apenas no início de 1900 é que são construídos os primeiros hotéis na capital paraibana. Mas o marco que representa a mudança de fases no desenvolvimento do turismo na Paraíba só ocorre em 1915 com a construção do 'Hotel Globo'. O Hotel Globo reinou absoluto até 1928, apesar de durante este período terem sido construídos hotéis com o objetivo de concorrer com o Globo nenhum conseguiu passar a sua frente. Em 1928 o hotel foi demolido e transferido para a residência do seu proprietário, no pátio São Pedro Gonçalves.

\begin{abstract}
A demolição do hotel e o aparecimento de um outro, maior e melhor, com a mesma marca, teve lances cinematográficos. Seu proprietário sempre foi homem rico, de bom gosto, empreendedor e altamente personalista. Atritouse com João Pessoa porque o presidente, ao receber informações negativas do hotel, de hóspedes seus convidados, exigia melhoramentos, inclusive um novo restaurante. Não chegaram a um acordo e o presidente João Pessoa resolveu construir o 'Paraíba Palace Hotel'. (GUIA DA PARAÍBA, 1985, p.87).
\end{abstract}

A demolição e a construção do novo Hotel Globo em 1928 ocorreu apenas como forma de provocação entre Siqueira (proprietário do hotel) e João Pessoa (então prefeito da capital paraibana), assim Siqueira construiu o que Leal (2001, p.67) descreve como um dos mais requintados hotéis da época. "O que havia de mais sofisticado no campo da hotelaria na Europa foi comprado. Vieram filtros da Alemanha e da Inglaterra; relógios suíços; foram comprados espelhos de cristais; mesas e cadeiras, em estilo colonial, vieram da Áustria [...]." (op. cit.).

Deste modo, os anos subsequientes demonstração a árdua competição entre o Hotel Globo e o Paraíba Palace Hotel, como mais requintado meio de hospedagem da capital paraibana. O primeiro no então sempre tomou a dianteira como mais sofisticado e bem frequientado por políticos e intelectuais da época. Apenas em 1950 com o falecimento de seu proprietário o Hotel Globo decai e o Paraíba Palace Hotel toma a frente.

A partir dos anos 80, em boa parte como consequiência das radicais transformações em frente ao hotel, para a construção de um viaduto e que eliminaram não só o estacionamento de automóveis como dificultaram muito o acesso de hóspedes, o 'Paraíba Palace Hotel' entra em total decadência. (GUIA DA PARAÍBA, 1985, p.87).

Assim o turismo na Paraíba toma outros rumos em direção ao litoral, com a construção do moderno 'Tropical Hotel Tambaú' pelo Governo do Estado (assim como os hotéis Bruxaxá em 1960 em Areia - PB e a Estância Termal do Brejo das Freiras em 1984 no município de São José do Rio do Peixe), mas no mesmo ano de sua construção o hotel foi vendido a Cia. Tropical de Hotéis, subsidiária da VARIG. 


\subsection{1 - Principais Atrativos Turísticos do Sertão Paraibano}

a) Patos - a cidade de Patos, em conjunto com Sousa, Catolé do Rocha e Cajazeiras formam os principais centros urbanos do Sertão da Paraíba. Esta cidade tenta desenvolver dois segmentos turísticos, que são o turismo de eventos e o religioso. Com relação ao turismo de eventos este é representado pela Festa de São João do município que é uma das maiores do Estado (depois do São João de Campina Grande), recebendo turistas da Paraíba, em especial da capital, e de estados vizinhos.

O turismo religioso fica por conta do 'Centro' Religioso da Cruz da Menina. Sua criação ocorreu no local onde uma jovem foi enterrada por seu pai adotivo que a espancava constantemente, em decorrência dos maus-tratos Francisca faleceu e seu corpo foi ocultado. Algum tempo depois o crime foi descoberto e um agricultor local fez uma prece a menina Francisca, com o alcance de sua graça o local onde o cadáver foi ocultado acabou por se tornam caminho de romeiros de outras cidades da região.

Figura 10: A Cruz da Menina - Patos/ PB

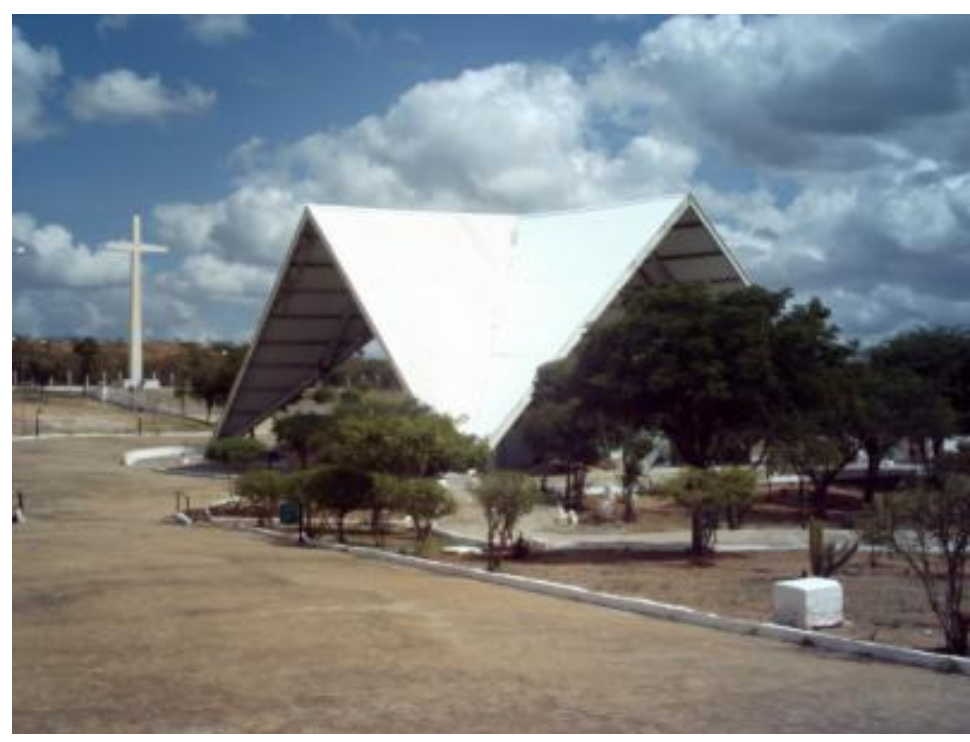

Fonte: Site www.paraiba.com.br

b) Sousa: a cidade se destaca em termos turísticos pela presença do 'Vale dos Dinossauros'. Este foi criado por terem sido descobertas pegadas de dinossauros fossilizadas. Mas não é apenas em Sousa que existem estas pegadas, em cerca de 30 localidades (nos municípios de: Aparecida, Marizópolis, Vieirópolis, São Francisco, São José da Lagoa Tapada, Santa Cruz, Santa Helena, Nazarezinho, Triunfo, Uiraúna, São João do Rio do Peixe e Cajazeiras) são encontradas pegadas fossilizadas de mais de 80 espécies de dinossauros. Mas apenas Sousa utilizou o achado como produto turístico, criando o 'Vale dos Dinossauros'. 
Figura 11: Vale dos Dinossauros - Sousa/ PB
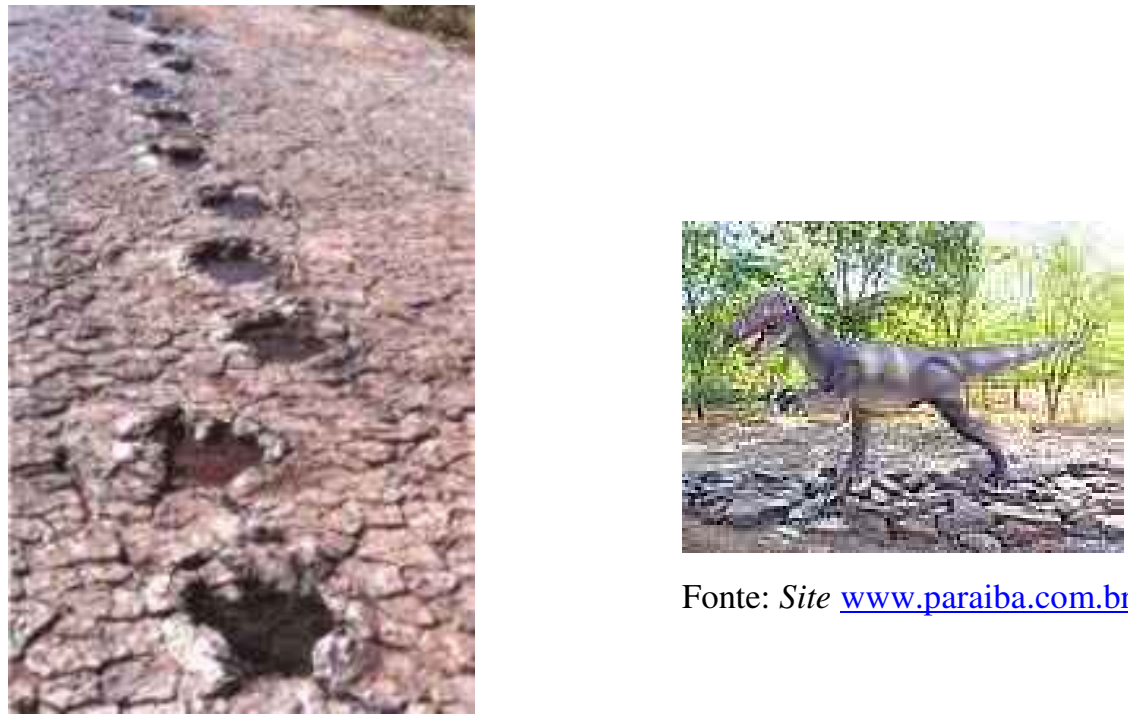

Fonte: Site www.paraiba.com.br

Fonte: Site www.paraiba.com.br

O Vale dos Dinossauros apresenta uma boa infra-estrutura, sendo considerado o maior atrativo turístico natural/ cultural do interior do Estado, constando sempre no material publicitário de divulgação do Estado da Paraíba, feito pela Empresa Paraibana de Turismo (PBTUR).

c) Estância Termal Brejo das Freiras: hotel de propriedade do Governo do Estado, que dispõem de águas/ lama consideradas medicinais e possui cinco fontes de águas termais. Devido a sua proximidade com o Vale dos Dinossauros em Sousa, recebe turistas que visitam o local.

Figura 12: Estância Termal Brejo das Freiras

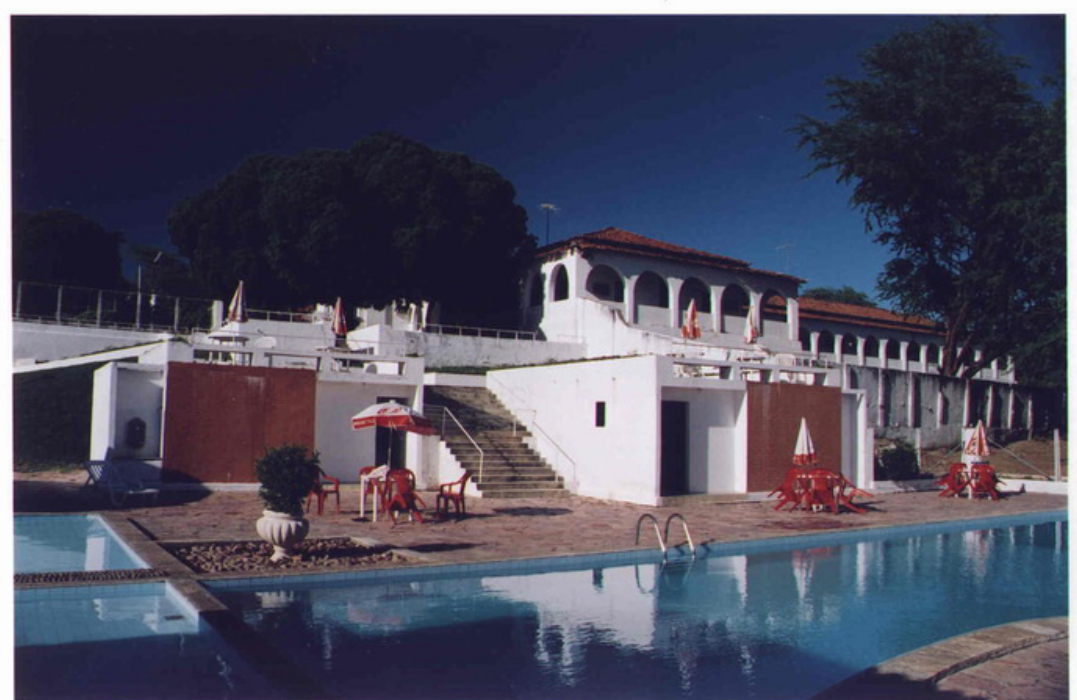

Fonte: Site http://www.ondehospedar.com.br/ 
d) Maturéia - o município de Maturéia, localizado na microrregião da Serra da Texeira, contem uma das Unidades de Conservação (UC's) do Estado da Paraíba, o Pico do Jabre. A UC's foi criada em 2002 em decorrência de sua ampla utilização por visitantes locais com a finalidade de escalada e caminhada. O pico é destaque dentro da Região Nordeste por ser o terceiro mais alto do Nordeste.

O Pico do Jabre, assim como as principais UC's paraibanas e brasileiras, não dispõe de infra-estrutura turística mínima, o que torna a sua utilização pelo turismo bastante incipiente.

Figura 13: Pico do Jabre - Maturéia/ PB

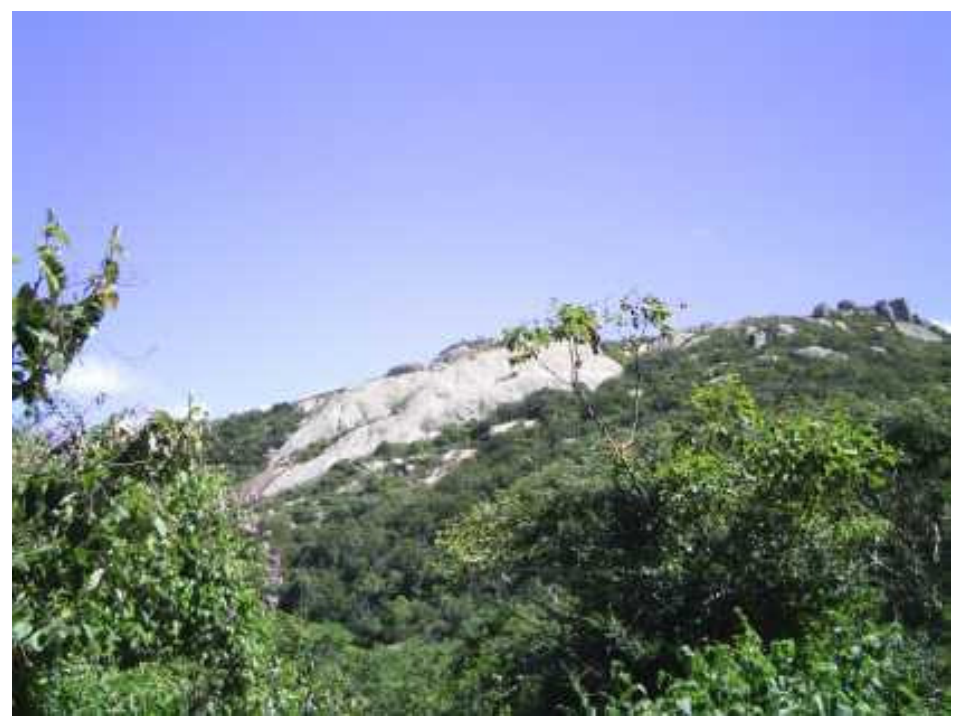

Fonte: Site da cidade de Patos http://www.patosnet.net/album

\subsection{2 - Principais Atrativos Turísticos da Borborema}

a) Cabaceiras: a cidade ganhou destaque por ser a de menor índice pluviométrico do Brasil. Apesar da realidade adversa, o município investiu maciçamente na criação de cabras/ bodes e no turismo, com o constante desenvolvimento destas atividades a cidade vem apresentando melhoria nas suas condições de vida, conseguindo, inclusive reduzir sua taxa de êxodo rural.

Cabaceiras possui como principais atrativos turísticos naturais as formações rochosas típicas de regiões semi-áridas assim como sua vegetação que além de atrair turistas, inclusive do exterior, também já serviu de cenário para vários filmes, o de maior destaque foi "O Auto da Compadecida". Os maiores atrativos naturais são: o Lajedo do Pai Mateus e a Saca de Lã. Além dos atrativos naturais a cidade também realiza um dos eventos de maior repercussão no Estado, a Festa do Bode Rei. 
Figura 14: Lajedo do Pai Mateus (Pedra do Capacete) - Cabaceiras/ PB

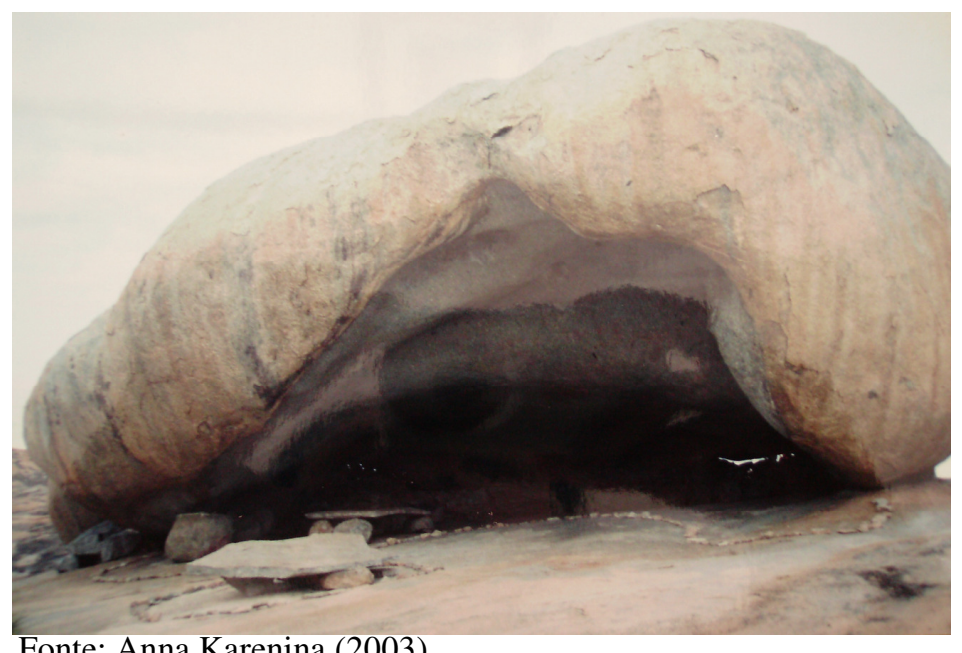

Fonte: Anna Karenina (2003).

\subsection{3 - Principais Atrativos Turísticos do Agreste}

a) Guarabira: a cidade tenta desenvolver o segmento do turismo religioso com os Caminhos do Padre Ibiapina e o Memorial de Frei Damião. Este último, é um monumento de 34 metros de altura, sendo a estátua com $21 \mathrm{~m}$ e o pedestal com $13 \mathrm{~m}$. A intenção é prestar uma homenagem ao Frei que passou por várias cidades do interior paraibano, dentre elas Guarabira.

Figura 15: Memorial de Frei Damião - Guarabira/ PB

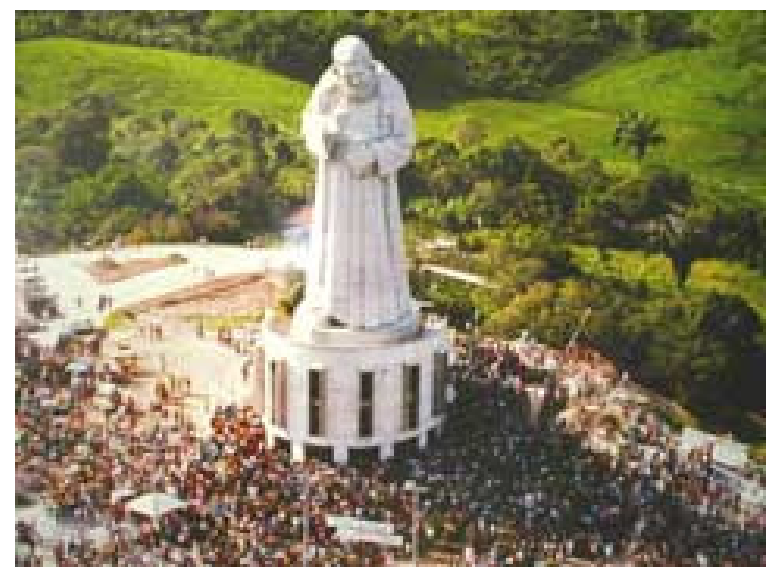

Fonte: Site www.chamada.com.br/mensagens/freidamiao.html

Os Caminhos do Padre Ibiapina é um projeto de autoria da Prefeitura de Guarabira em parceria com o SEBRAE/PB. São 242 km, com um duração aproximada de três a quatro dias, voltados para peregrinos de todo o Brasil, que poderão ser feitos à pé, bicicleta ou cavalo, sempre entre os dias 15 a 19 de cada mês, durante todo o ano. O percurso é encerrado com uma missão no dia do falecimento do Padre Ibiapina (dia 19) no Santuário da Santa Fé. 
b) Pirpirituba: na divisória entre o pequeno município de Pirpirituba e Bananeiras está a maior queda da água do Estado, com aproximadamente 30 metros de altura, a Cachoeira do Roncador recebe um pequeno número de turistas interessados principalmente na prática do canyoning, trekkers e montanhismo.

Figura 16: Cachoeira do Roncador - Divisa entre Pirpirituba/ PB e Bananeiras/ PB

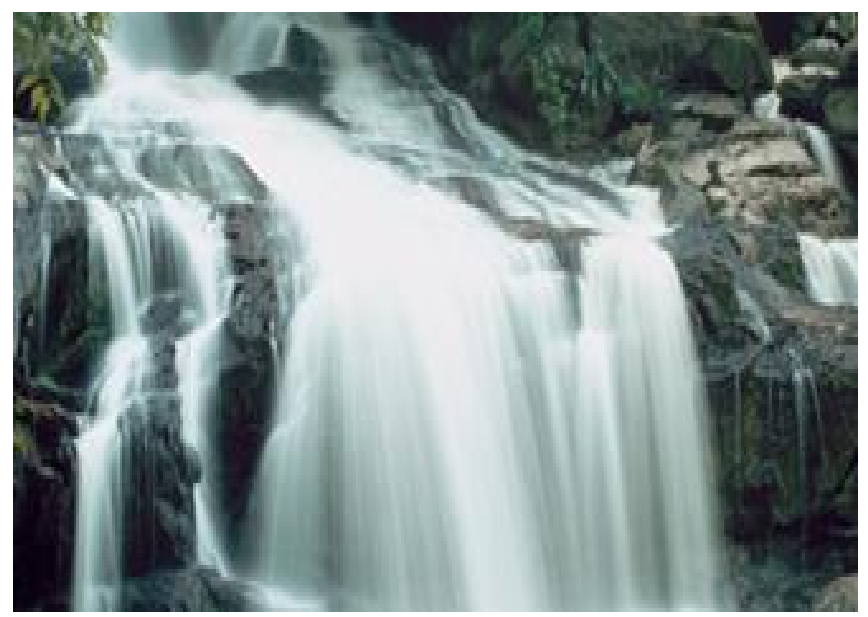

Fonte: Site www.paraiba.com.br

c) Areia: a cidade se destaca no turismo do Estado pelos seus eventos, os de maior destaque são: o Bregareia e o Festival de Arte; e pelo seu patrimônio histórico, vários sobrados do século XVIII ainda são preservados no local assim como as casas de Pedro Américo de Almeida e José Américo de Almeida. Também desenvolve o turismo rural nas fazendas produtoras de rapadura e cachaça presentes na área rural de Areia.

d) Campina Grande: a segunda cidade mais importante da Paraíba, é o berço dos grandes eventos realizados no Estado. O maior de todos é o São João, sendo considerado, em conjunto com Caruaru/ PE, a maior festa junina do país. Além do São João também realiza outros eventos de grande destaque na Paraíba: o Encontro para a Nova Consciência; Vaquejada Maria da Luz; Micarande e o Congresso de Violeiros.

Figura 17: Festa de São João - Campina Grande/ PB

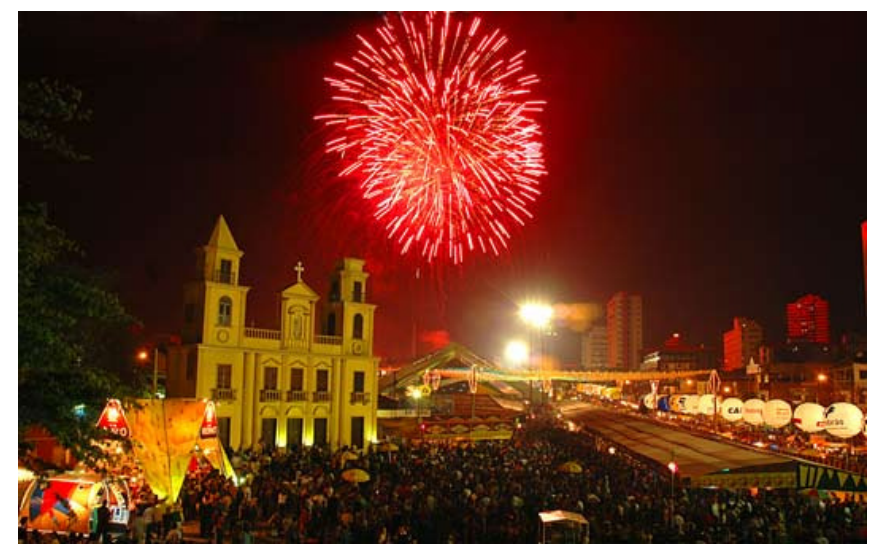

Fonte: Site http://www.campinagrande.pb.gov.br/cidade.htm. 
e) Araruna: no município de Araruna, que faz divisória entre os Estados da Paraíba e do Rio Grande do Norte esta outra UC's de destaque no segmento ecoturístico da Paraíba, o Parque Estadual da Pedra da Boca, onde se pratica principalmente rappel.

Figura 18: Pedra da Boca - Araruna/ PB

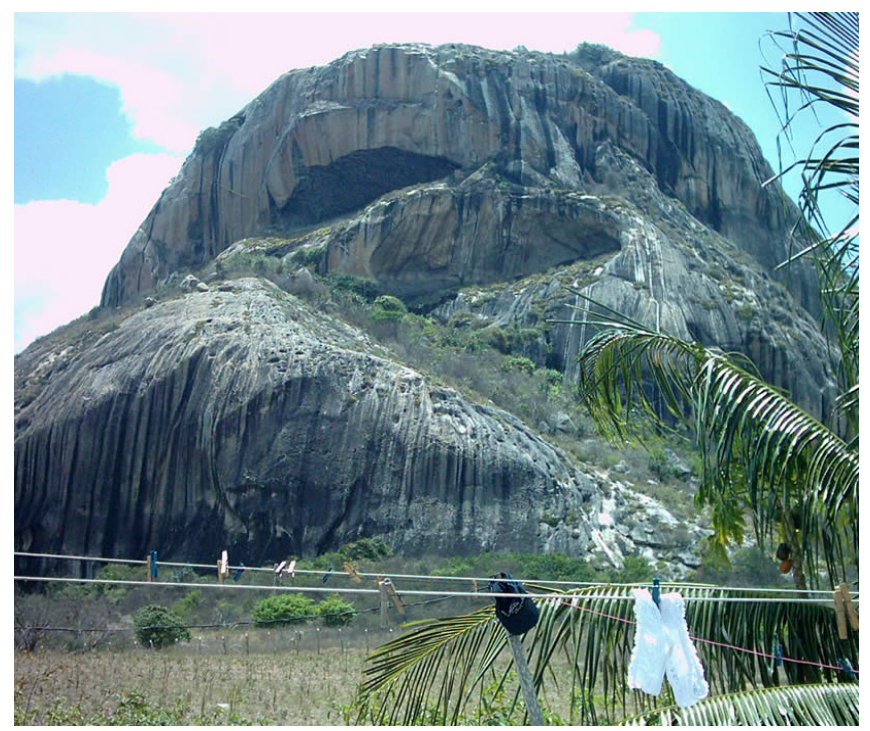

Fonte: Site www.paraiba.com.br

f) Ingá: a cerca de $40 \mathrm{~km}$ da cidade de Campina Grande estão localizadas as Itacoatiaras do Ingá, formada por uma série de blocos de gneiss com inscrições rupestres de origem ainda desconhecida. Outro 'mistério' do local é uma pedra que quando tocada por um objeto de metal (a exemplo de uma moeda) emite um som semelhante ao badalar de um sino. As Itacoatiaras do Ingá foram tombadas pelo Instituto do Patrimônio Histórico e Artístico Nacional (IPHAN) em 1944.

Figura 19: Itacoatiaras do Ingá - Ingá/ PB

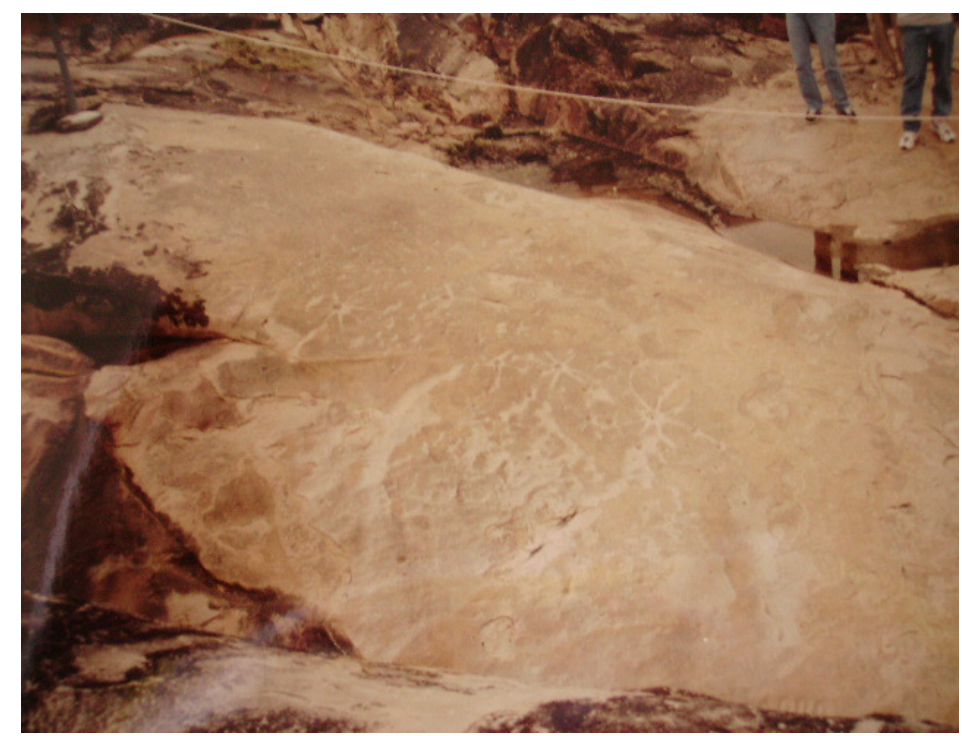

Fonte: Anna Karenina (2002). 


\subsection{4 - Principais Atrativos da Zona da Mata}

O principal atrativo turístico da Zona da Mata Paraibana são as praias, com destaque para as praias urbanas do Cabo Branco, Manaíra e Tambaú, localizadas em João Pessoa e que dispõem de ampla infra-estrutura hoteleira e de serviços. Na Praia de Tambaú, próximo ao famoso Tropical Hotel Tambaú, a dez minutos deste, está Picãozinho, um arrecife de corais amplamente visitado por turistas. Outro atrativo muito visitado pelos turistas é o Farol do Cabo Branco, deste ponto é possível ter uma visão privilegiada do extremo oriental das Américas, a Ponta do Seixas.

O município vizinho do Conde (Litoral Sul da Paraíba) também utiliza suas praias como atrativo turístico. A principal delas é Tambaba, primeira praia de naturismo do Nordeste, é considerada ponto de referência deste segmento no Brasil.

Em Cabedelo, a principal Praia é a de Camboinha onde são realizados vários eventos tais como o Festverão Paraíba, Campeonatos de Surf e famosos Luaus, no entanto, seu maior destaque se dá no segmento de veraneio. É da praia de Camboinha que saem as embarcações com destino a Areia Vermelha, pequena ilha que emerge quando a maré baixa, onde é possível praticar mergulho.

Além de Areia Vermelha o pôr-do-sol da Praia do Jacaré (praia fluvial) ao som do bolero de ravel tocado por todos os bares/ restaurantes do local por dois saxofonistas, atrai muitos turistas representando um dos principais atrativos do Estado. O pôr-do-sol do Jacaré já foi considerado pelo Guia Quatro Rodas (2003) o terceiro mais bonito de todo o país.

Figura 20: Pôr-do-sol na Praia do Jacaré - Cabedelo/ PB

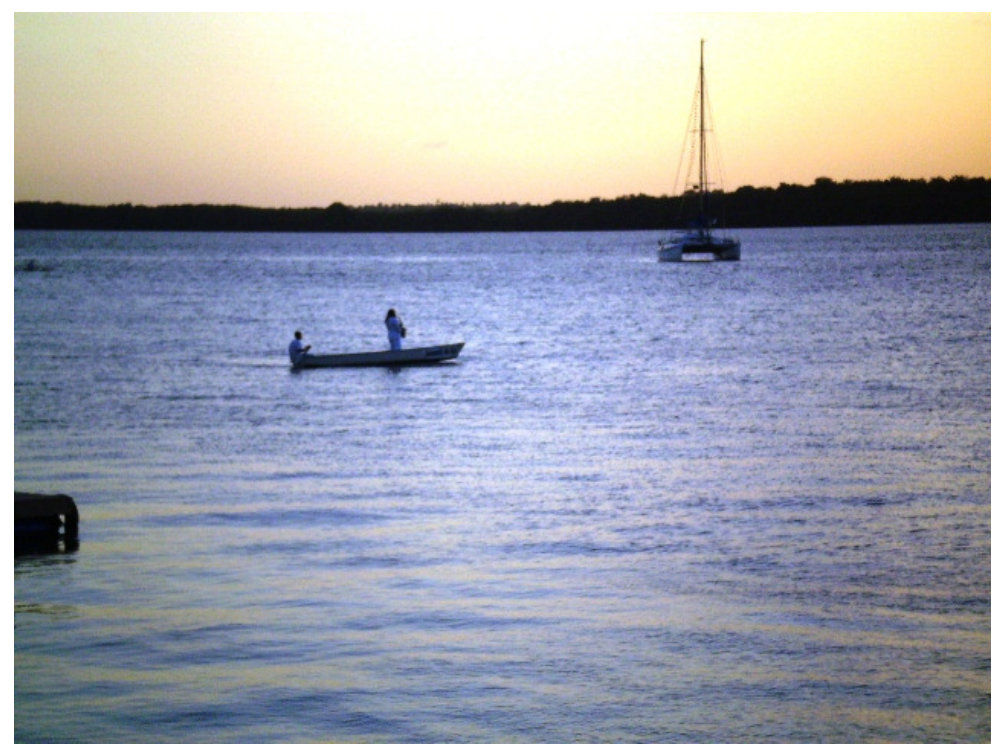

Fonte: Anna Karenina (2006). 
É em Cabedelo que está localizado o único porto ativo do Estado, nos últimos três anos o Porto de Cabedelo tem iniciado de modo mais consistente sua utilização como receptor de cruzeiros marítimos, anualmente recebe uma média de cinco ou seis navios com número variado de passageiros (aproximadamente entre 150 a 400, segundo pesquisa realizada in loco pela autora em 2004 durante trabalho de conclusão de curso de graduação).

Apesar das praias representarem os principais atrativos turísticos da mesorregião da Zona da Mata, a cidade de João Pessoa tenta explorar seus atrativos históricos/ culturais. Segundo Leal (2001, p.36) "a capital da Paraíba, nos dias atuais é apontada como a 'segunda cidade mais verde do mundo', a 'terceira cidade mais antiga do Brasil e 'onde o sol chega mais cedo nas Américas"”.

Desta forma vem se tentando utilizar o centro histórico como atrativo turístico, a partir da revitalização de seus sobrados, com destaque para as casas presentes na Praça Antenor Navarro já revitalizadas e para o Hotel Globo (também revitalizado) e Casa da Pólvora de onde se pode ter uma visão privilegiada do Rio Sanhauá. Também são muito visitadas a Igreja de São Francisco e o Mosteiro de São Bento, em decorrência de seu grande acervo de obras barrocas e pela própria estrutura arquitetônica destes.

Figura 21: Casa da Pólvora - João Pessoa/ PB

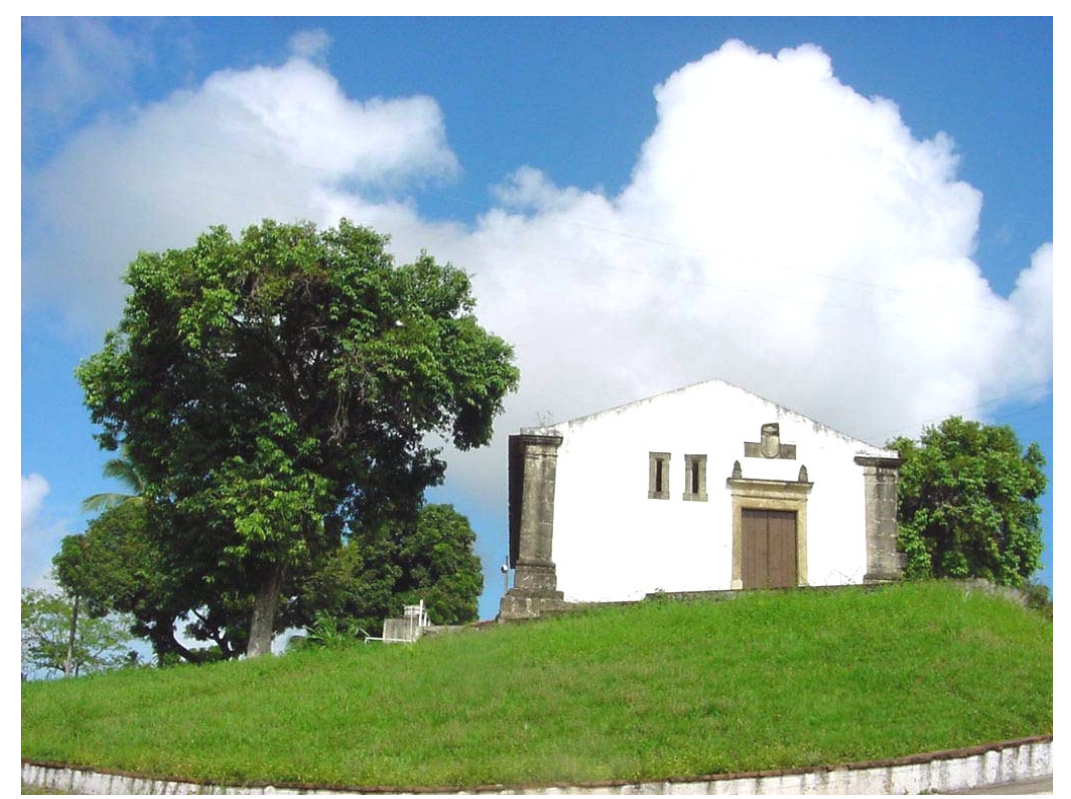

Fonte: Ricardo Paulo - CD turístico: Guia turístico da cidade de João Pessoa (2001).

Os municípios de Cabedelo e Lucena também realizaram programas de revitalização, o primeiro no Forte de Cabedelo e o segundo na Igreja da Guia ambos considerados patrimônios históricos pelo Instituto de Patrimônio Histórico do Estado da Paraíba (IPHAEP). 
Figura 22: Igreja de Nossa Senhora da Guia - Lucena/ PB

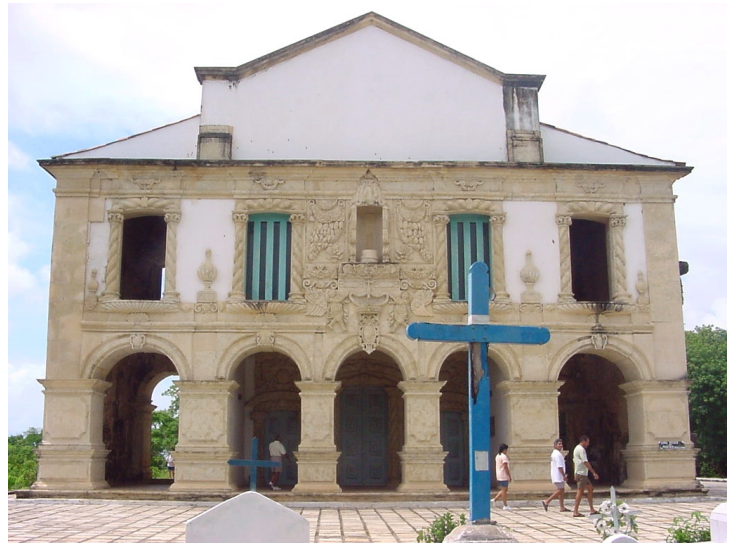

Fonte: Ricardo Paulo - CD turístico: Guia turístico da cidade de João Pessoa (2001).

Apesar da cidade de Campina Grande ser o grande destaque no segmento de turismo de eventos no Estado, não só por já possuir um amplo Centro de Convenções (Raimundo Ásfora) e o maior hotel do Estado (Garden), mas também pelas suas festas populares (São João, encontro de violeiros, vaquejadas, etc.). A cidade de João Pessoa também possui uma festa popular de grande apelo turístico, o Folia de Rua. Este evento marca a comemoração das prévias carnavalescas e tem amplo apoio da população local, dentre os vários blocos carnavalescos o de maior destaque é o Muriçocas do Miramar, segundo maior bloco de arrasto do Brasil, perdendo apenas para o Galo da Madrugada de Recife - PE em número de foliões e de carros alegóricos.

Figura 23: Bloco das Muriçocas do Miramar (Folia de Rua) - João Pessoa/ PB

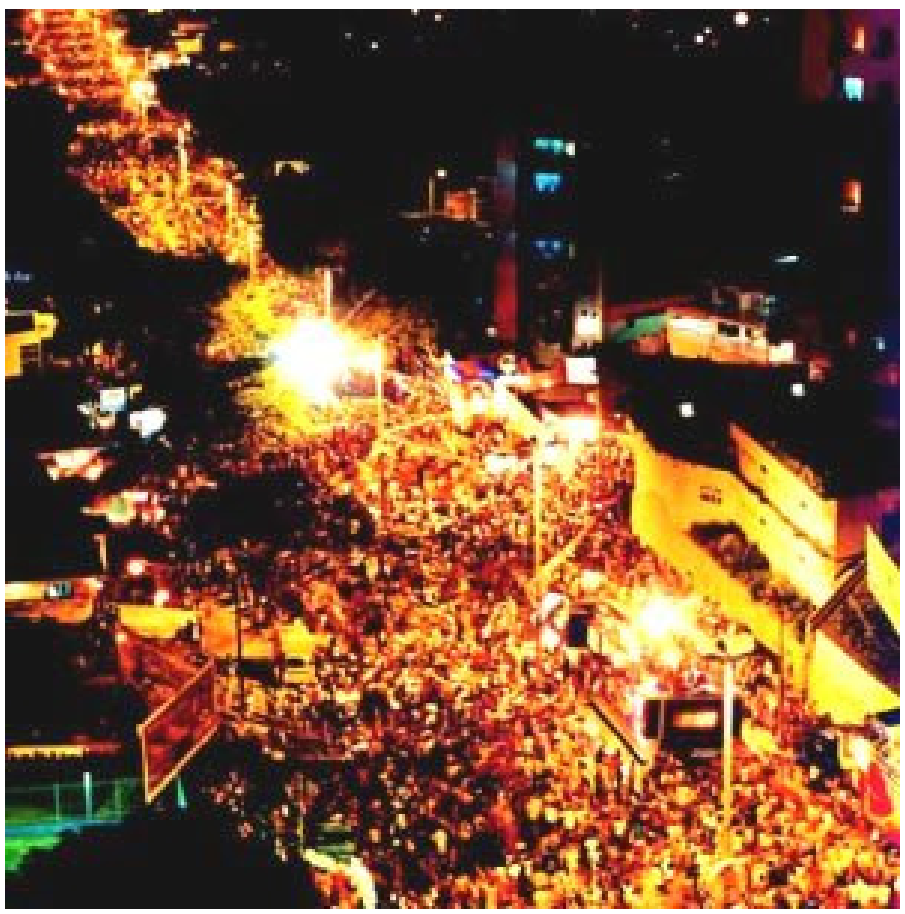

Fonte: Site das Muriçocas do Miramar (http://www.muricocas.com.br/) 


\subsection{5 - Políticas Públicas de Turismo na Paraíba}

Apesar de terem ocorrido ações conceituadas por alguns autores, a exemplo de Leal (2001), em prol do desenvolvimento do turismo no período anterior a 1970, acreditamos que a atividade turística só começa a se desenvolver no Estado a partir da década de 70 com a inauguração do Tropical Hotel Tambaú. Isso porque a maioria das pessoas que visitavam a Paraíba no período anterior a 70 não podia ser conceituada como turistas (apenas uma pequena parcela visitava o Estado com finalidade exclusivamente turística) já que estabeleciam atividades relacionadas com suas ocupações e a cidade não dispunha de equipamentos que favorecessem a visita de turistas. Deste modo, o turismo de acordo com seu conceito atual só teve início de fato na década de 1970.

Mas a década de 70 não se destacou apenas pela construção do Hotel Tambaú, no início desta década foi criada a Secretaria de Turismo do Município de João Pessoa (SETUR/JP). Alguns anos mais tarde em 1975 foi criado o primeiro órgão estadual de turismo na Paraíba, a Empresa Paraibana de Turismo (PBTUR).

\footnotetext{
Entre seus vários objetivos, encontravam-se os seguintes: adquirir, explorar, direta ou por concessão, hotéis, motéis, restaurantes, campings, balneários e outros empreendimentos turísticos; incrementar e fomentar o turismo no Estado, promovendo pesquisas, planejamentos e estudos; criar mecanismos que possam contribuir para o fortalecimento e desenvolvimento do setor. Leal (2001, p.193).
}

A princípio a PBTUR ficou vinculada à Secretaria da Indústria e Comércio. Mas em 2002 foi criada a Secretaria Estadual de Turismo e Desenvolvimento Econômico e atualmente a PBTUR se encontra vinculada a esta.

Como já observamos no capítulo anterior a primeira grande ação em prol do desenvolvimento do turismo na Paraíba se deu na década de 80 (Projeto Cabo Branco) elaborado pela PBTUR em parceira com diversos órgãos (Embratur, Banco do Nordeste, SEBRAE, etc.) no Governo de Tarcísio Burity, mas este pouco ou nada realizou de concreto. Sucedendo Burity, na gestão do governador Ronaldo Cunha Lima, a PBTUR cria o Projeto Costa do Sol, que nada mais é do que uma imitação (com algumas poucas modificações) do Projeto Cabo Branco, mas este último assim como seu predecessor não obtém êxito praticamente nenhum.

Apesar de algumas ações pontuais do Estado com o intuito de atrair turistas, como a criação da Estância Termal do Brejo das Freiras em São José do Rio do Peixe, a criação do Centro de Informações Turísticas de Tambaú em frente ao Hotel Tambaú 
(onde atualmente funciona a sede da PBTUR) e o Mercado de Artesanato (MAP) também no bairro de Tambaú, não é elaborada nenhuma política mais consistente de turismo na Paraíba até a década de 1990 quando é criado o Plano de Turismo da Paraíba (PLANTUR/ PB).

Segundo Passos (2002, p.110) O Plantur estabeleceu dois eixos turísticos: o eixo litoral, constituído pelos municípios de João Pessoa, Cabedelo, Conde, Rio Tinto e Baía da Traição; e o eixo interior formado pelos municípios do Agreste e Sertão paraibano como Campina Grande, Sousa, Patos, Cajazeiras, Coremas, Santa Luzia, Sapé, Ingá e Areia (PLANTUR-PB, 1991). O eixo litoral polarizado por João Pessoa constitui o atrativo principal, enquanto o eixo interior, polarizado por Campina Grande, é considerado um atrativo suporte, evidenciando a posição do poder público em adotar o modelo sol e praia. O Plantur constituiu três diretrizes para o setor turístico:

a) Institucional - visando à integração do turismo na Paraíba a todos os estados nordestinos articulando o governo federal, os organismos financiadores nacionais e internacionais e a iniciativa privada, cabendo à empresa paraibana de turismo S/A PBTUR, a gestão do Plantur.

b) Político-geográfica - busca o planejamento espacial das ações, representada pela regionalização do espaço turístico paraibano.

c) Potencialização dos pólos turísticos tradicionais - revitalizando e estimulando os maiores destinos turísticos paraibanos como os municípios de João Pessoa com $72 \%$ do fluxo turístico estadual e Campina Grande com 24\% em 1990.

No Governo de José Targino Maranhão no início de 2000 é criado o Plano Amanhacer. Ele foi baseado nas teorias de pólos de crescimento, que já estavam sendo utilizadas pelo órgão federal de turismo (EMBRATUR) no Programa Nacional conhecido como Pólos de Ecoturismo, a PBTUR ao invés de criar pólos voltados para apenas um segmento turístico (como o que foi feito pela EMBRATUR) criou pólos voltados para distintos segmentos nas quatro mesorregiões do Estado, o programa foi estruturado em quatro fases:

a) diagnóstico e estratégia de desenvolvimento realizado nos anos de 1999 e 2000;

b) plano operacional previsto para iniciar em fevereiro de 2000 e finalizar em maio do mesmo ano;

c) estruturação da oferta da Paraíba entre 2000 a 2002;

d) crescimento do número de turistas, delimitado no período de 2003 a 2010. 
Os pólos criados foram em todas as messoregiões da Paraíba de acordo com seus atrativos, sendo, no entanto dado maior destaque a cidade de João Pessoa como podemos observar no quadro abaixo:

Quadro 08: Pólos criados pelo Plano Amanhecer

\begin{tabular}{|l|l|}
\hline \multicolumn{1}{|c|}{ Pólos } & \multicolumn{1}{|c|}{ Recursos } \\
\hline $\begin{array}{l}\text { Pólo 1: João } \\
\text { Pessoa }\end{array}$ & $\begin{array}{l}\text { Centro Cultural de São Francisco, Praça Antenor Navarro, Cidade de João Pessoa, } \\
\text { Espaço Cultural José Lins do Rego, Farol do Cabo Branco, Forte de Santa Catarina. }\end{array}$ \\
\hline $\begin{array}{l}\text { Pólo 2: Costa das } \\
\text { Piscinas }\end{array}$ & $\begin{array}{l}\text { Praia do Seixas, Piscinas naturais de Picãozinho, Piscinas naturais de Areia } \\
\text { Vermelha, Praia de Tambaba, Praia de Tambaú, Praia de Jacumã. }\end{array}$ \\
\hline Pólo 3: Peixe Boi & $\begin{array}{l}\text { Igreja da Guia, Habitat do Peixe-Boi, Cidade de Rio Tinto, Reserva Indígena } \\
\text { Potiguaras, Reserva Biológica Guaribas, Ruínas de São Miguel, Cidade de Baía da } \\
\text { Traição, Ruínas de Bom Sucesso, Cidade de Lucena. }\end{array}$ \\
\hline $\begin{array}{l}\text { Pólo 4: Campina } \\
\text { Grande }\end{array}$ & $\begin{array}{l}\text { São João de Campina Grande, as Itacoatiaras do Ingá, Lajedo do Pai Mateus em } \\
\text { Cabaceiras. }\end{array}$ \\
\hline $\begin{array}{l}\text { Pólo 5: Serra dos } \\
\text { Engenhos }\end{array}$ & \begin{tabular}{l} 
Cidade de Areia e Bregareia. \\
\hline Pólo 6: Caatinga
\end{tabular} \\
\hline
\end{tabular}

Fonte: Adaptado de Passos (2002, p. 123).

Assim como os programas anteriores de desenvolvimento do turismo o Plano Amanhecer também não teve prosseguimento, o maior responsável pelo 'engavetamento' deste programa foi a descontinuidade política. Atualmente no Estado existem dois 'grupos' políticos 'rivais' formados pelo PMDB cujo principal representante é Maranhão e o PSD formado por Cássio Cunha Lima (atual Governador e filho do ex-governador Ronaldo Cunha Lima). Como estes dois grupos se revezam no poder os programas de turismo criados na gestão de um grupo não é continuado pelo outro, ocorrendo assim a elaboração de 'novas' políticas públicas de turismo na Paraíba a cada mandato.

Atualmente não existe nenhuma macropolítica elaborada pelo Governo do Estado da Paraíba com a intenção de desenvolver o turismo. Os órgão responsáveis pelo turismo no Estado parecem estar mais voltados a dar apoio a projetos criados por secretarias municipais de turismo que atendam as regiões consideradas pela instituição de potencial turístico. O potencial turístico da Paraíba é formado pelo mapa a seguir. 


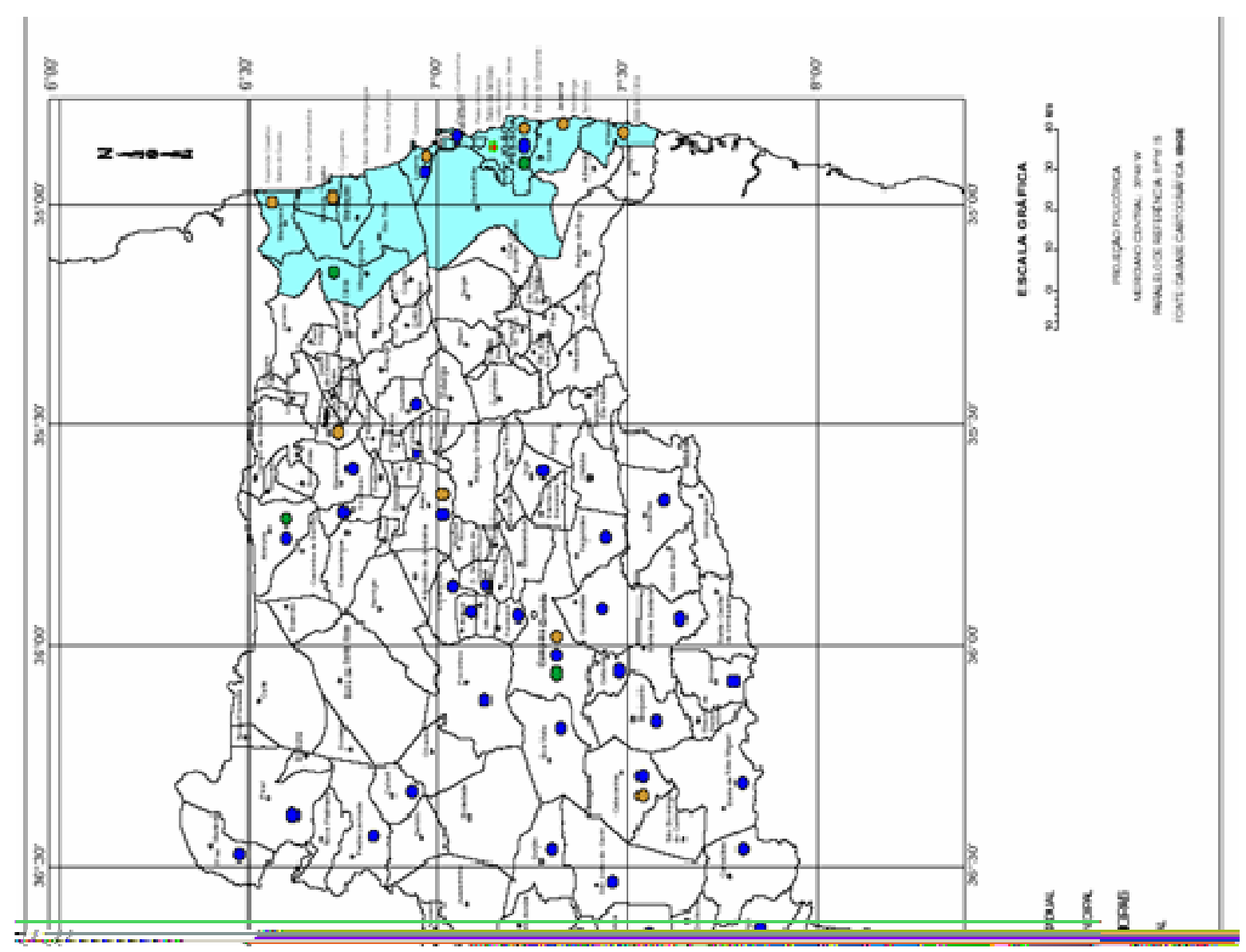




\subsection{6 - Indicadores do Turismo na Paraíba}

Os estudos de turismo no Brasil como um todo ainda são pouco consistentes, há uma falta de dados estatísticos que permitam análises mais aprofundadas especialmente em locais que ainda não são considerados grandes receptores de turismo. Na verdade, estes dados deveriam ser coletados in loco pelas próprias secretarias municipais de turismo e/ ou estaduais, no entanto, a falta de verbas e de pessoal, ou mesmo a inoperância de alguns destes órgãos, acaba por inviabilizar tais estudos, que são básicos para o planejamento do turismo.

Os anuários da EMBRATUR apresentam alguns dados relativos ao fluxo de turistas que desembarcaram na Paraíba, no período posterior a implementação do PRODETUR na Paraíba. Podemos observar alguns destes dados na tabela abaixo.

Quadro 09: Movimento de Passageiros em Vôos Nacionais nos Aeroportos da Paraíba

\begin{tabular}{|c|c|}
\hline Ano & Desembarque \\
\hline 1999 & 115.196 \\
\hline 2000 & 132.788 \\
\hline 2001 & 155.379 \\
\hline 2002 & 149.429 \\
\hline 2003 & 134.760 \\
\hline 2004 & 135.340 \\
\hline 2005 & 193.084 \\
\hline
\end{tabular}

Fonte: Anuários da EMBRATUR (2001, p.140, p.141; 2002 p.141; 2003 p.141; 2004 p.157; 2005 p.186, p.178).

O número de desembarques na Paraíba é o segundo menor de todo o Nordeste, sendo superior apenas do que o estado do Piauí nos anos de 1999, 2001, 2002, 2003, 2004 e 2005. No ano 2000, Alagoas apresentou o pior número de desembarque de todo o Nordeste sendo menor inclusive do que os da Paraíba e do Piauí. A Bahia, em todos os anos analisados possui o maior número de desembarques nacionais seguido por Pernambuco.

Os dados relativos a desembarque de vôos internacionais são praticamente inexpressivos já que os aeroportos paraibanos não recebem vôos regulares internacionais.

Apesar da pouca importância dos aeroportos paraibanos, comparativamente aos dos demais estados do Nordeste, a capital paraibana no ano de 2003 e 2004 apresentou 
dados bastante expressivos dentro do Nordeste e até mesmo do Brasil no quesito transporte rodoviário interestadual, ocupando a segunda posição, com relação às demais capitais do Nordeste, em número de desembarque de passageiros e a $20^{\text {a }}$ com relação as demais cidades brasileiras, segundo o anuário da EMBRATUR (2005, p.180).

Quadro 10: Movimentação Interestadual de Passageiros nas Rodoviárias das Principais Capitais Nordestinas

\begin{tabular}{|c|l|c|c|}
\hline Posição & \multicolumn{1}{|c|}{ Nome } & $\mathbf{2 0 0 3}$ & $\mathbf{2 0 0 4}$ \\
\hline $\left.1^{\circ}\right)$ & Recife (PE) & 954.215 & 713.977 \\
\hline $\left.2^{\circ}\right)$ & João Pessoa (PB) & 501.755 & 379.441 \\
\hline $\left.3^{\circ}\right)$ & Salvador (BA) & 392.369 & 362.799 \\
\hline $\left.4^{\circ}\right)$ & Fortaleza (CE) & 321.948 & 323.744 \\
\hline $\left.5^{\circ}\right)$ & Aracajú (SE) & 325.724 & 318.283 \\
\hline $\left.6^{\circ}\right)$ & Natal (RN) & 245.621 & 275.795 \\
\hline $\left.7^{\circ}\right)$ & Teresina (PI) & 272.072 & 267.004 \\
\hline $\left.8^{\circ}\right)$ & Maceió (AL) & 386.550 & 266.864 \\
\hline
\end{tabular}

Fonte: Anuário da EMBRATUR (2005, p.180).

Isoladamente a capital paraibana detém um bom resultado em comparação com a Região Nordeste, mas se considerarmos o fluxo total de passageiros interestaduais de todas as rodoviárias da Paraíba esta apresentava a $4^{\mathrm{a}}$ colocação (atrás do Ceará, Pernambuco e Bahia) nos anos de 2004 e 2005, segundo Anuário da EMBRATUR (2006, p.196).

Possivelmente a posição central da Paraíba na Região Nordeste possibilita que as pessoas que residem ou visitam estados vizinhos possam ter acesso a João Pessoa utilizando transportes terrestres (como ônibus e automóveis), já que a distância é relativamente pequena. Uma viagem de Recife a João Pessoa de ônibus não dura mais que duas horas, de Natal para João Pessoa a duração da viagem de ônibus é de aproximadamente três horas. A posição da Paraíba entre dois mercados turísticos solidificados pode representar um ponto negativo, já que muitos turistas podem optar por passar poucos dias, ou até mesmo horas, na cidade de João Pessoa, fazendo com que a capital paraibana sirva na prática como um 'atrativo' de Natal e de Recife, e utilizando estas últimas como o verdadeiro destino turístico. Por outro lado, pode representar um ponto positivo, fazendo com que turistas que visitam as capitais pernambucana e 
potiguar se sintam motivados a conhecer João Pessoa, e nas férias seguintes considerar a cidade como destino turístico principal. Além da posição central, o valor e a disponibilidade de passagens aéreas para João Pessoa, em especial em anos anteriores, dificultavam ainda mais as viagens aéreas para a capital paraibana.

Como já foi mencionado anteriormente, as estatísticas relacionadas ao turismo são muito escassas. Quando pensamos em transportes, não podemos deixar de citar dois fatores, o primeiro é o fato de que nem todos os viajantes são turistas, dentro dos números apresentados anteriormente há possivelmente um grande número de viajantes que não são turistas. Como segundo ponto, devemos nos lembrar que no Brasil os meios de transporte mais utilizados são: avião, ônibus e automóveis. A incerteza causada pela crise aérea aumentou ainda mais a utilização dos dois últimos meios de transportes. $\mathrm{O}$ fluxo de turistas que visitam determinado local de automóvel nem sempre são contados, e mesmo se existe uma contagem destes pela polícia rodoviária, por exemplo, constatamos o mesmo problema, como saber quais são turistas ou não. Em decorrência destes fatores é praticamente impossível demonstrar estatísticas que representem exatamente o fluxo de turistas em uma determinada cidade.

O Banco do Nordeste, com a intenção de demonstrar o desenvolvimento que o PRODETUR causou no turismo no Nordeste elaborou um relatório denominado 'efeitos globais do PRODETUR I', segundo este documento, o comportamento do fluxo turístico assim como dos gastos e das receitas geradas pelo turismo na Paraíba pode ser observado abaixo:

Quadro 11: Indicadores do Turismo na Paraíba 1996/ 2004

\begin{tabular}{|c|c|c|c|}
\hline Ano & $\begin{array}{c}\text { Fluxo Turístico } \\
\text { (em mil) }\end{array}$ & $\begin{array}{c}\text { Gasto per capita } \\
\text { (em } \mathbf{R} \$ \text { ) }\end{array}$ & $\begin{array}{c}\text { Receita Turística } \\
\text { (em R\$ mil) }\end{array}$ \\
\hline 1996 & 560 & 219,29 & 122.802 \\
\hline 1997 & 521 & 267,43 & 139.331 \\
\hline 1998 & 756 & 235,49 & 178.030 \\
\hline 1999 & 633 & 238,37 & 150.888 \\
\hline 2000 & 762 & 250.92 & 191.201 \\
\hline 2001 & 833 & 736,06 & 613.138 \\
\hline 2002 & 909 & 598,67 & 544.191 \\
\hline 2003 & 759 & 769,34 & 583.929 \\
\hline 2004 & 949 & 709,69 & 673.496 \\
\hline
\end{tabular}

Fonte: Adaptado de TELES - Banco do Nordeste (2005, p.24). 


\title{
6. APRESENTAÇÃO E ANÁLISE DOS RESULTADOS DA PESQUISA
}

\section{1 - O Funcionamento do PRODETUR/NE}

O programa foi criado, como já mencionando, anteriormente com o objetivo de dotar os estados de infra-estrutura básica urbana e de acesso para que assim estes pudessem desenvolver o turismo.

\begin{abstract}
O objetivo básico do Programa é reforçar a capacidade da Região Nordeste em manter e expandir sua crescente indústria turística contribuindo assim para o desenvolvimento sócio-econômico regional. O Programa proverá infra-estrutura básica e serviços públicos em áreas atualmente de expansão turística. Tais investimentos beneficiarão principalmente a população de baixa renda das áreas selecionadas, aumentando a capacidade do Estado de acompanhar a demanda por serviços básicos. Ao melhorar as condições destas áreas o Programa procura também atrair as atividades turísticas privadas adicionadas e de melhor padrão, gerando assim oportunidades de emprego, melhoramento dos níveis de renda e aumento de receitas públicas. O cumprimento destes objetivos dar-se-á através da implantação das estratégias turísticas desenvolvidas pelos Estados, previstas nos planos de ação destinados a atividade turística e a participação privada do setor. Fonte: Banco do Nordeste - Relatório Final - Anexo A (2005, p.05).
\end{abstract}

O objetivo macro do programa como podemos observar é o desenvolvimento do turismo através do investimento especialmente em infra-estrutura, mas segundo o Banco do Nordeste (2005, p.06) o programa possui os seguintes objetivos específicos:

- Atrair atividades turísticas privadas adicionais e de melhor padrão;

- Gerar oportunidades de emprego;

- Melhorar os níveis de renda;

- Aumentar as receitas públicas;

- Beneficiar a população de baixa renda das áreas selecionadas com disponibilização dos serviços de abastecimento de água, esgotos e acessos pavimentados;

- Aumentar a capacidade dos Estados beneficiados de acompanhar a demanda por serviços básicos.

Visando essas ações o programa se estrutura a partir da concessão de crédito para a aplicação nas seguintes linhas de atuação: Desenvolvimento institucional; Obras múltiplas em infra-estrutura e serviços públicos (subdivido em saneamento, gerenciamento de resíduos sólidos, recuperação/ proteção ambiental, transporte urbano/ rodoviário, recuperação do patrimônio histórico); Estudos e projetos.

A primeira linha de atuação, desenvolvimento institucional, tem o objetivo principal de ampliar a capacidade das entidades participantes de executar suas funções. 
Já a última pretendia propiciar a elaboração de estudos e projetos referentes a obras passíveis de implantação no âmbito do programa em sua segunda fase.

O quadro 12 demonstra os objetivos específicos, metas e ações alcançadas pelo segundo componente do projeto (infra-estrutura) em todo Nordeste.

Quadro 12: Ações de Infra-estrutura do PRODETUR/ NE Fase I

OBRAS MÚLTIPLAS EM INFRA-ESTRUTURA BÁSICA E SERVIÇOS PÚBLICOS

\begin{tabular}{|c|c|}
\hline \multicolumn{2}{|c|}{$\begin{array}{l}\text { A) Saneamento } \\
\text { Objetivo: melhorar os serviços públicos de abastecimento de água e tratamento de esgoto, nas } \\
\text { áreas abrangidas pelo Programa. Na maioria dos casos, os trabalhos visam ampliar, } \\
\text { simultaneamente, a capacidade dos sistemas tanto de abastecimento de água quanto de } \\
\text { esgotamento sanitário, aproveitando o máximo as instalações existentes. }\end{array}$} \\
\hline Planejado & Alcançado \\
\hline $\begin{array}{l}\text { Sub-setor água potável } \\
\text { Os trabalhos incluem a construção ou } \\
\text { reabilitação de: } \\
\text { - captação de água; } \\
\text { - poços; } \\
\text { - adutoras; } \\
\text { - estações de tratamento; } \\
\text { - reservatórios; } \\
\text { - redes de distribuição; } \\
\text { - ligações domiciliares com medição; } \\
\text { - bombas } \\
\text { - outros equipamentos de medição }\end{array}$ & $\begin{array}{l}\text { Sub-setor água potável } \\
\text { - Rede de distribuição: } \underline{706,8 \mathrm{~km}} \\
\text { - Adução: } \underline{121,3 \mathrm{~km}} \\
\text { - Estações de tratamento de água implantadas: } \\
\underline{25 \text { unidades }} \\
\text { - Ligações domiciliares até set/ } 2005: \underline{50.472} \\
\underline{\text { unidades }} \\
\text { - População atendida até set/ } 2005: \underline{474.514} \\
\text { habitantes. }\end{array}$ \\
\hline $\begin{array}{l}\text { Meta: } \\
-41 \text { projetos } \\
-8 \text { estados }\end{array}$ & $\begin{array}{l}\text { Meta Alcançada: } \\
\text { - } 30 \text { projetos (4 não inicialmente previstos); } \\
-8 \text { estados. } \\
\text { Valor Aplicado } \\
\text { - BID: US\$ } 39.870 .687(62,9 \%) \\
\text { - LOCAL: US\$ } 23.475 .634(37,1 \%) \\
\text { TOTAL: US\$ } 63.346 .321\end{array}$ \\
\hline $\begin{array}{l}\text { Sub-setor esgotamento sanitário } \\
\text { Está prevista a construção de: } \\
\text { - redes de esgotos; } \\
\text { - coletores tronco; } \\
\text { - estações elevatórias; } \\
\text { - estações de tratamento. }\end{array}$ & $\begin{array}{l}\text { Sub-setor esgotamento sanitário } \\
\text { - Rede de coleta de esgoto: } \underline{1.090,1 \mathrm{~km}} \\
\text { - Interceptores/ emissários: } \underline{137,6 \mathrm{~km}} \\
\text { - Estações de tratamento de } \\
\text { implantadas: } \underline{29 \text { unidades }} \\
\text { - Ligações domiciliares até set/ } 2005: \underline{71.932} \\
\underline{\text { unidades }} \\
\text { - População atendida até set/2005: } \underline{670.463} \\
\text { habitantes. }\end{array}$ \\
\hline $\begin{array}{l}\text { Meta: } \\
-42 \text { projetos } \\
-8 \text { estados }\end{array}$ & $\begin{array}{l}\text { Meta Alcançada: } \\
\text { - } 39 \text { projetos (16 não inicialmente previstos) } \\
-9 \text { estados } \\
\text { Valor Aplicado } \\
\text { - BID: US\$ } 78.385 .279(80 \%) \\
\text { - LOCAL: US\$ } 19.536 .758(20 \%) \\
\text { TOTAL: US\$ } 97.922 .037\end{array}$ \\
\hline
\end{tabular}


Objetivos:

1) proporcionar uma coleta apropriada e eficiente dos resíduos sólidos no meio urbano; 2) proporcionar um transporte eficiente e econômico dos resíduos até a área de despejo final; 3) proporcionar uma eliminação ecologicamente segura, tecnicamente prática e de baixo custo; 4) promover programas de educação ambiental e de longo alcançe orientado à mudança de atitude da população para conseguir sua cooperação e tornar a coleta mais eficiente; 5) fortalecer as instituições em seus aspectos técnicos e financeiros, a fim de assegurar sua operação e manutenção com um custo eficiente, tanto no curto como no longo prazo; 6) proteger a saúde e segurança de seus trabalhadores.

\begin{tabular}{|l|l|}
\hline \multicolumn{1}{|c|}{ Planejado } & \multicolumn{1}{|c|}{ Alcançado } \\
\hline Meta do Sub-Componente & Meta Alcançada \\
- 19 projetos & -0 projetos \\
- 6 Estados & -0 Estados \\
& \\
Valor Previsto & Valor Aplicado \\
- BID: US\$ 8.550.000 & US\$ 0,00 \\
- LOCAL: US\$ 2.050.000 & \\
TOTAL: US\$ 10.600 .000 & \\
\hline
\end{tabular}

\section{C) Recuperação e Proteção Ambiental}

Objetivos:

Melhorar/ manter a qualidade ambiental de áreas de interesse turísticos, por meio de investimentos em estudos, educação ambiental, manejo, preservação/ recuperação de recursos naturais em determinados territórios dentro da área de abrangência do programa.

\begin{tabular}{|l|l|}
\hline \multicolumn{1}{|c|}{ Planejado } & \multicolumn{1}{c|}{ Alcançado } \\
\hline Meta do Sub-componente & Metas Alcançadas \\
- 15 projetos & -18 projetos (7 previstos; 11 adicionais) \\
- 7 Estados & - 4 Estados \\
& - Área protegida/ recuperada: 11.202 ha \\
& - O programa contribuiu para a conservação \\
(criação de APAs) de 102.925 ha \\
& - Foram criadas 6 Unidades de Conservação, \\
& todas na Bahia \\
Valor Previsto & Valor Aplicado \\
- BID: US\$ 19.500.000 & - BID: US\$ 6.303.674 \\
- LOCAL: US\$ 3.900.000 & - LOCAL: US\$ 14.245.756 \\
TOTAL: US\$ 23.400.000 & TOTAL: US\$ 20.549.430 \\
\hline
\end{tabular}

\section{D) Transporte (obras viárias urbanas/ rodovias)}

Objetivos

Propiciar acesso cômodo, confiável e seguro a zonas turísticas, melhorar a circulação urbana e diminuir congestionamentos associados ao acesso a zonas de interesse turístico.

\begin{tabular}{|l|l|}
\hline \multicolumn{1}{|c|}{ Planejado } & \multicolumn{1}{c|}{ Alcançado } \\
\hline Sub-Setor Rodovias & Sub-Setor Rodovias \\
$\begin{array}{l}\text { Construção, melhoramento e reabilitação de } \\
\text { caminhos e rodovias prioritárias. }\end{array}$ & - Extensão de rodovias pavimentadas: 978,1 \\
& $\underline{\mathrm{km}}$ \\
& Valor Aplicado \\
& - BID: US\$ 86.521.177 \\
& - LOCAL: US\$29.231.385 \\
& TOTAL: US\$ 115.752 .562 \\
\hline & \\
\hline
\end{tabular}




\begin{tabular}{|c|c|}
\hline $\begin{array}{l}\text { Sub-Setor Vias Urbanas } \\
\text { Reabilitação de vias urbanas e drenagem } \\
\text { destinadas a melhorar a circulação urbana e } \\
\text { diminuir o congestionamento para facilitar o } \\
\text { acesso a zonas de interesse turístico. As obras, } \\
\text { entre outras, incluem: } \\
\text { - remodelação de ruas e avenidas; } \\
\text { - habilitação de vias para pedestres; } \\
\text { - ciclovias e as correspondentes obras de } \\
\text { drenagem }\end{array}$ & $\begin{array}{l}\text { Sub-Setor Vias Urbanas } \\
\text { - Extensão de vias pavimentadas: } \underline{47 \mathrm{~km}} \\
\\
\text { Valor Aplicado } \\
\text { - BID: US\$ } 23.423 .114 \\
\text { - LOCAL: US\$ } 3.021 .686 \\
\text { TOTAL: US\$ } 26.44 .800\end{array}$ \\
\hline \multicolumn{2}{|l|}{ E) Recuperação do Patrimônio Histórico } \\
\hline \multicolumn{2}{|c|}{$\begin{array}{l}\text { Objetivos: } \\
\text { 1) Recuperar monumentos históricos principalmente da época colonial e constituí-los focos de } \\
\text { atração turística; 2) Revitalizar o contorno urbano de áreas geralmente degradadas mas com } \\
\text { potencial cultural, comercial e habitacional; 3) promover a participação do setor privado nessas } \\
\text { atividades. }\end{array}$} \\
\hline Planejado & Alcançado \\
\hline $\begin{array}{l}\text { Meta do Sub-Componente } \\
\text { - } 7 \text { projetos } \\
\text { - } 6 \text { Estados }\end{array}$ & $\begin{array}{l}\text { Metas Alcançadas } \\
\text { - } 17 \text { projetos (6 previstos e } 11 \text { adicionais) } \\
\text { - } 7 \text { Estados } \\
\text { - No sítios históricos contemplados: } \underline{14} \\
\text { - } \mathrm{N}^{\mathrm{o}} \text { edificações recuperadas: } \underline{61} \\
\text { - Área construída recuperada: } \underline{94.814 \mathrm{~m}^{2}} \\
\text { - Enterramento de rede elétrica: } \underline{11.000 \mathrm{~m}} \\
\text { - Enterramento de rede telefônica: } \underline{11.000 \mathrm{~m}} \text {. }\end{array}$ \\
\hline $\begin{array}{l}\text { Valor Planejado } \\
\text { - BID: US\$ } 30.000 .000 \\
\text { - LOCAL: US\$ 5.900.000 } \\
\text { TOTAL: US\$ } 35.900 .000\end{array}$ & $\begin{array}{l}\text { Valor Aplicado } \\
\text { - BID: US\$ } 35.035 .963 \\
\text { - LOCAL: US\$ } 10.596 .215 \\
\text { TOTAL: US\$ 45.632.178 }\end{array}$ \\
\hline
\end{tabular}

Fonte: Adaptado do Banco do Nordeste - Relatório 01 (2005, p.15).

Com base no quadro 12, podemos concluir a veracidade da colocação de Cruz (2000, p.10) a respeito do PRODETUR/ NE se parecer mais com uma política urbana do que de turismo.

O caráter de política urbana do programa nos remete a um questionamento. Pouco investimento é concedido ao turismo no Nordeste em especial nos estados do Maranhão, Alagoas, Sergipe, Piauí e Paraíba, em decorrência da escassez de recursos das secretarias de turismo destes Estados. Caberia, então, a uma política pública de turismo (setor com escasso investimento) investir em uma área que 'teoricamente' não seria da sua jurisdição? , já que as obras de infra-estrutura as quais engloba o programa, em sua maioria, nos parecem estar mais relacionadas com as secretarias estaduais de infra-estrutura, departamentos de estradas e rodagens, entre outros do que diretamente com o turismo. 
Num primeiro momento, pensamos que a atividade turística ocorre de forma integrada dentro de um sistema, como vimos anteriormente, onde todas as variáveis se relacionam. Sem estradas, limpeza urbana, segurança, saneamento, não existe turismo. Assim quando da elaboração de um plano de turismo estas variáveis devem representar uma preocupação para o planejador. Mas cabe realizarmos uma breve consideração sobre a utilização de verbas turísticas para 'outros setores'. Pela necessidade de infraestrutura ampliada para a realização do turismo alguns governantes acabam por se utilizar de verbas do PRODETUR em locais que não deveriam ser prioritários para o turismo, com a finalidade única de atender a interesses próprios e não da atividade turística.

Se um determinado bairro recebe mais turistas que outros, e neste local existe escassez de infra-estrutura a verba deve contemplar o bairro mais turístico, prioritariamente, e não os demais. É muito fácil justificar o emprego de uma verba para promover o turismo, qualquer investimento em infra-estrutura é importante para o turismo, mas existe uma primazia de ações que deveria ser respeitada.

Apesar de o programa conter um discurso de melhoria da qualidade de vida da população carente com a criação de emprego e infra-estrutura para locais pobres, os investimentos se dirigiram em sua maioria aos locais menos pobres do Nordeste, a exemplo dos estados da Bahia e Ceará. Conforme podemos observar no gráfico 04:

Gráfico 04: Recursos aplicados nos estados nordestinos

PRODETUR/NE I

VALORES APLICADOS* POR ESTADO E FONTE

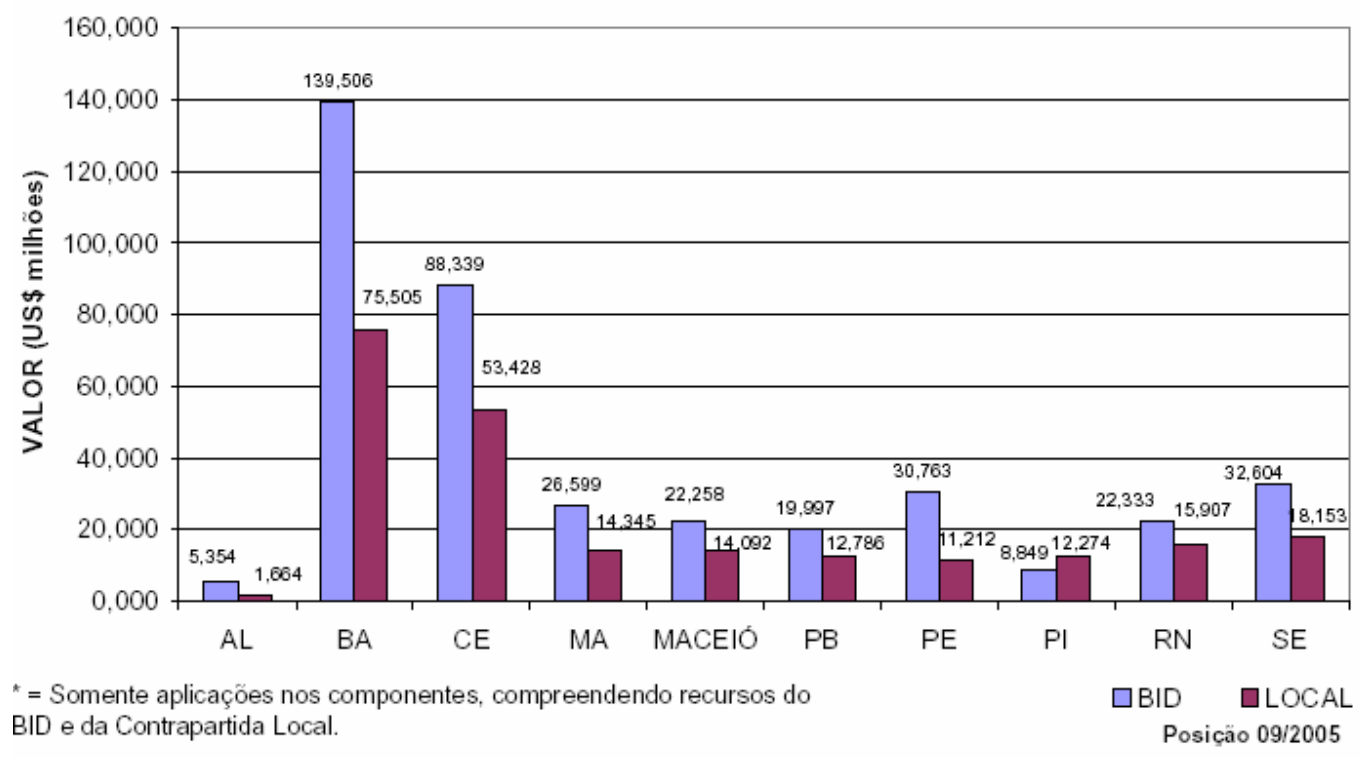

Fonte: Banco do Nordeste - Relatório 02 (2005, p.18). 
E mesmo dentro daqueles Estados mais pobres, os recursos se concentraram nas capitais e em seu entorno, que são os locais mais desenvolvidos (com maior IDH, renda per capita, entre outros).

Neste ponto, devemos questionar a forma como os governantes enxergam o que vem a ser caracterizado como potencial turístico ou área turística, e o PRODETUR como uma ilustração desta visão míope. O programa escolheu prioritariamente as capitais nordestinas e alguns outros municípios, especialmente os litorâneos, em sua primeira fase, porque estes poderiam ser considerados de vocação turística, já que para muitos 'vocação turística é sinônimo de litoral', mas 'coincidentemente' estes municípios também eram os mais desenvolvidos.

E mesmo dentro de localidades pouco desenvolvidas, citemos como exemplo a cidade de João Pessoa, capital paraibana, quando pensamos em infra-estrutura voltada para o turismo devemos focalizar prioritariamente nos locais mais visitados pelos turistas, na cidade de João Pessoa estes locais são: Praia do Cabo Branco, Praia de Tambaú, Bairro do Manaíra, Bairro do Bessa e Bairro do Centro. Dos locais citados, apenas o Bairro do Centro, onde se localiza o Centro Histórico, Porto do Capim, Igreja de São Francisco, Mosteiro de São Bento, entre outros, representa um local onde não habita a parcela da população mais privilegiada. No entanto, os demais bairros são conhecidamente habitados por pessoas de maior poder aquisitivo.

Se o programa pretende de fato investir nos locais considerados turísticos, então irá investir, na maioria das vezes, nas localidades (cidades e bairros) onde está concentrada a população mais favorecida economicamente e não na periferia.

Se seguirmos a visão de que o litoral representa a única localidade do Nordeste onde se pode desenvolver o turismo, dificilmente a atividade turística irá representar um instrumento para a melhoria da qualidade de vida da população. No capítulo anterior ao demonstrar as diferenças entre as mesorregiões paraibanas percebemos que a Zona da Mata é a localidade com melhores indicadores sócio-econômicos. Está realidade não é observada apenas na Paraíba. A Zona da Mata Nordestina é a região mais dinâmica de todos os estados do Nordeste, assim investir exclusivamente nesta região representa aumentar ainda mais as diferenças sócio-econômicas das mesorregiões nordestinas.

Realizando uma análise mais detalhada da concentração espacial dos recursos do PRODETUR/NE I podemos fazer uma relação entre a extensão litorânea dos estados nordestinos e o percentual de investimentos em cada estado, conforme a tabela 04 a seguir. 
Tabela 04: Extensão territorial do litoral x investimentos do PRODETUR/ NE I

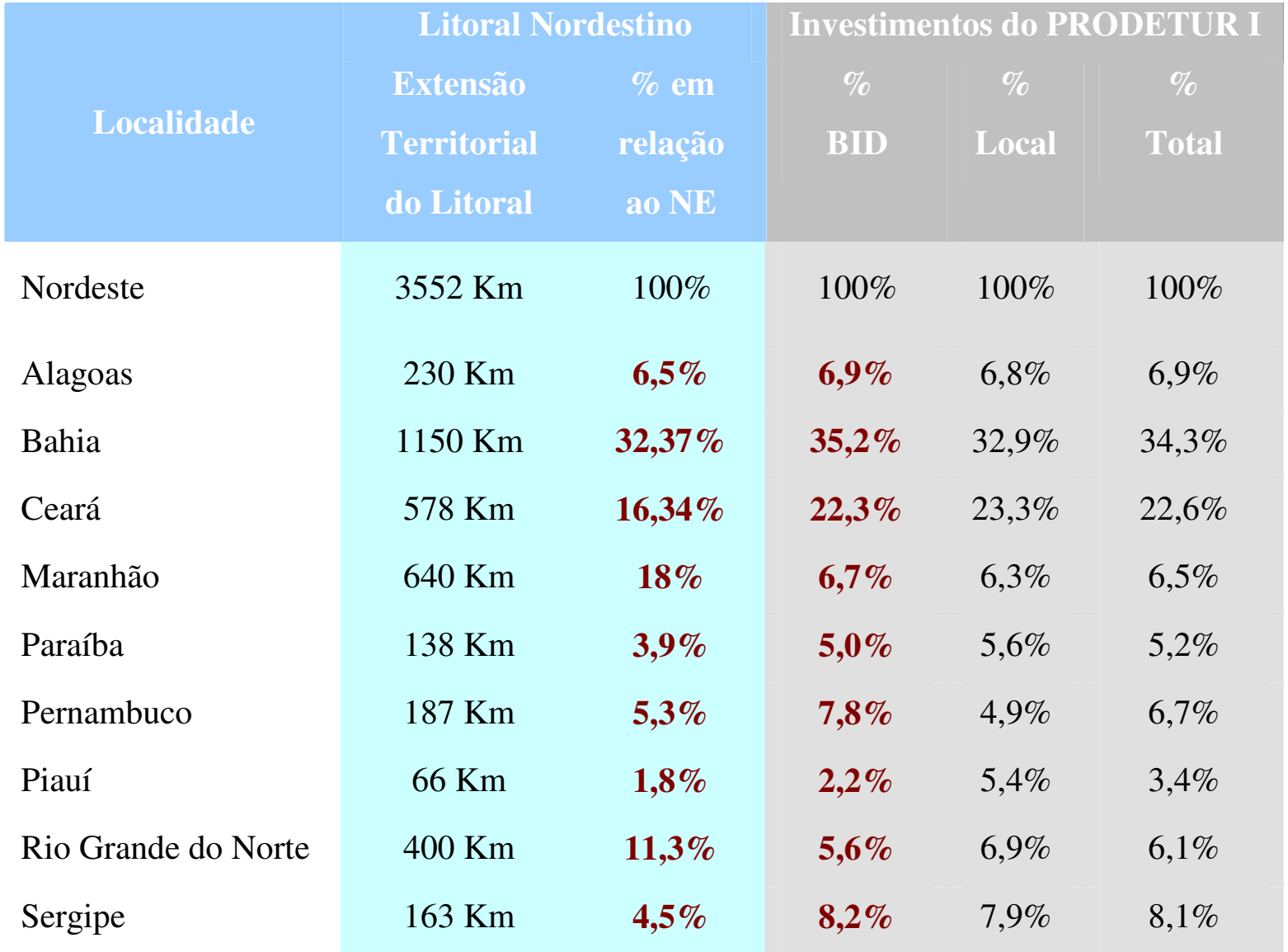

Fonte: Baseado em dados do site www.viajemaisbrasil.com.br; www.brasilazul.com.br; Adaptado de TELES; Banco do Nordeste (2005, p.09).

Com base na tabela 04 podemos perceber a relação existente entre extensão do litoral e porcentagem de recursos. Na maioria dos casos, a porcentagem de extensão do litoral corresponde a aproximadamente a porcentagem de recursos repassados pelo BID.

Uma das grandes críticas ao PRODETUR/NE I é justamente o fato de ele privilegiar cidades litorâneas, em especial capitais, contribuindo para a expansão do turismo de sol e mar, caracterizado como turismo de massa, em detrimento do incentivo de outros segmentos de turismo menos impactantes e voltados para municípios menos desenvolvidos a exemplo do turismo sertanejo, e do turismo rural.

Os recursos do BID privilegiaram locais que já são grandes receptores de turismo no Nordeste e no Brasil, as capitais dos estados do Ceará e Bahia, Fortaleza e Salvador. Estes estão entre os destinos mais visitados do Nordeste, segundo dados da EMBRATUR. Inclusive, de acordo com o anuário da EMBRATUR (2005, p.141), a cidade de Salvador foi a quarta destinação mais visitada por turistas estrangeiros no Brasil no ano de 2004 e a primeira mais visitada no Nordeste, enquanto que Fortaleza 
no mesmo ano foi a sexta no Brasil e a segunda no Nordeste. No ano anterior Salvador foi a terceira cidade mais visitada no Brasil por estrangeiros e a primeira do Nordeste, Recife foi a quinta no Brasil, Fortaleza foi a sétima no Brasil e terceira no Nordeste, segundo o anuário da EMBRATUR (2004, p.144).

Possivelmente, a posição estratégica destes destinos se deve também aos investimentos do PRODETUR, apesar das capitais pernambucana e potiguar não terem recebido grandes recursos do programa e mesmo assim se manterem entre os destinos mais visitados do Nordeste e até mesmo do Brasil.

Uma outra questão a qual cabe breve comentário é a participação popular na escolha das ações efetuadas pelo programa. As unidades executoras do programa não realizaram nenhum sistema de consulta a população das localidades onde os investimentos foram feitos. Entendemos que algumas ações do programa, a exemplo da construção de rodovias que possibilitaram o acesso de turistas a praias antes habitadas apenas pela população autóctone, representaram grande modificação no cotidiano dos nativos, o que justificaria um empenho das unidades executoras para realizar um trabalho de consulta, integração e até mesmo de conscientização, da população dentro das ações do programa. Se a intenção do programa fosse de fato beneficiar a população local, e não transformar seu espaço em produto a ser comercializado para o capital externo, os grupos de pescadores locais e os habitantes destas áreas litorâneas deveriam ter sido ouvidos quando da decisão da alocação dos recursos.

O próprio relatório do programa afirma que não foi possível integrar a população local no programa, relatando inclusive alguns conflitos/ insatisfações da população que discordou com algumas ações do programa. "Conflitos com moradores quanto à alocação das obras de alguns projetos, devido à deficiente realização de consulta às comunidades afetadas durante a fase de elaboração de projetos”. Banco do Nordeste Relatório 01 (2005, p.16)

Quando o turismo se 'apropria' de determinadas localidades litorâneas pertencentes a grupos de pescadores, por exemplo, estes acabam por vender suas casas a baixos preços. Fazendo com que corretores e imobiliárias, num futuro próximo, se beneficiem da especulação imobiliária lucrando muito com o alto valor que estes terrenos passam a ter. Esta situação, em muitos casos, faz com que os investidores não invistam nestas localidades em decorrência dos preços serem muito elevados. Ver anexo II com o exemplo do município do Conde na Paraíba. E acabam por tirar o sustento de grupos de pescadores que se vêem privados até mesmo de seu local de trabalho. 


\section{2 - Apresentação das Ações do PRODETUR na Paraíba}

Os investimentos do PRODETUR/ NE no estado da Paraíba ocorreram em diversos campos. Em sua primeira fase o programa contribuiu para ações de desenvolvimento institucional, saneamento na forma de abastecimento de água e esgotamento sanitário, projeto de transporte com a construção de rodovias, recuperação de patrimônio histórico, elaboração de projetos/ estudos.

As ações da segunda fase do PRODETUR/ NE na Paraíba não podem ser alvo de avaliação já que segundo a coordenadora de projetos do PRODETUR/ PB, Sra. Catharine Brasil, em questionamento realizado no dia 30 de agosto de 2007, a segunda fase do PRODETUR na Paraíba ainda está em estágio de planejamento não tendo sido efetivada ação alguma até o momento da pesquisa, a não ser a formação do Pólo Costa das Piscinas. Sendo assim, a pesquisa do trabalho em questão se resume as ações do programa na Paraíba em sua primeira fase.

Cabe destacar que os quesitos de recuperação/ preservação ambiental e construção/ recuperação de aeroportos não foram contemplados pelo PRODETUR/ PB primeira fase.

A maior parte dos investimentos em recuperação/ preservação ambiental foram para o Estado da Bahia que criou seis novas unidades de conservação, já com relação a recuperação/ construção de aeroportos, os aeroportos de Cunha Machado (São Luís MA); Pinto Martins (Fortaleza - CE); Augusto Severo (Natal - RN); Santa Maria (Aracajú - SE); 2 de Julho (Salvador - BA); Guararapes (Recife - PE); Aeroporto de Lençóis (Bahia) e Aeroporto de Porto Seguro (Bahia) forma os únicos contemplados. Apesar das péssimas condições do Aeroporto Presidente Castro Pinto (Bayeux - PB) este não foi contemplado pelo PRODETUR possivelmente por já existir um projeto para ampliação e reforma do mesmo elaborado pelo Governo do Estado ${ }^{13}$. O outro aeroporto do Estado, João Suassuna, localizado em Campina Grande, também não foi beneficiado pelo programa.

Com relação aos projetos de desenvolvimento institucional, o Banco do Nordeste - Relatório 02 (2005, p.22) destaca que o principal deles para o Estado da Paraíba foi a elaboração de planos diretores em municípios do litoral paraibano (Baía da

\footnotetext{
${ }^{13}$ Com relação ao projeto de reforma e ampliação do aeroporto não podemos deixar de destacar a morosidade deste, apesar de ter suas obras iniciadas a mais de cinco anos atrás o projeto só foi concluído no segundo semestre de 2007. A demora em sua reforma ocorreu em decorrência da falta de verba do Governo, que por duas vezes parou a obra por este motivo.
} 
Traição, Conde, Lucena, Marcação, Pitimbú e Rio Tinto), os recursos para a efetivação deste projeto vieram todos do BID e somaram US\$238.214,33. A verba destinada a Paraíba pelo BID para a realização do principal projeto de desenvolvimento institucional correspondeu a aproximadamente $1,91 \%$ do total investido, o estado que recebeu mais recursos do BID neste quesito foi Alagoas (US\$ 5.081.165,92) com $40,87 \%$ do total dos recursos, e os estados que menos foram contemplados com recursos do BID foram os estados de Sergipe e Ceará, ambos não receberam nenhuma verba, contaram apenas com recursos locais.

Mas não foi apenas na elaboração de planos diretores dos municípios do litoral paraibano que o PRODETUR através de recursos do BID atuou no desenvolvimento institucional da Paraíba, o quadro 13, demonstra em que outros setores os recursos foram empregados.

Quadro 13: Ações do PRODETUR em Desenvolvimento Institucional na Paraíba

\begin{tabular}{|l|c|c|c|c|c|}
\hline \multicolumn{1}{|c|}{ Projeto } & \multicolumn{3}{|c|}{ Recursos } & $\begin{array}{c}\text { Data Início } \\
\text { Desembolso }\end{array}$ & $\begin{array}{l}\text { Data Final } \\
\text { Desembolso }\end{array}$ \\
\cline { 2 - 5 } & BID & Local & Total & & \\
\hline A) SUDEMA humanos: & $11.915,99$ & 627,16 & $12.543,15$ & $05 / 06 / 2000$ & $31 / 08 / 2000$ \\
\hline $\begin{array}{l}\text { Desenvolvimento } \\
\text { recursos } \\
\text { treinamentos internos }\end{array}$ & & & & & \\
\hline $\begin{array}{l}\text { Fortalecimento das estruturas } \\
\text { operacionais: centro de } \\
\text { transportes }\end{array}$ & $61.701,38$ & $10.399,51$ & $72.100,89$ & $07 / 12 / 2000$ & $24 / 01 / 2001$ \\
\hline $\begin{array}{l}\text { Fortalecimento das estruturas } \\
\text { operacionais: consultorias }\end{array}$ & $28.154,65$ & 721,91 & $28.876,56$ & $17 / 04 / 2001$ & $17 / 04 / 2001$ \\
\hline $\begin{array}{l}\text { Fortalecimento das estruturas } \\
\text { operacionais: equipamentos } \\
\text { de informática }\end{array}$ & $42.833,48$ & $4.117,87$ & $46.951,35$ & $05 / 06 / 2001$ & $17 / 05 / 2005$ \\
\hline $\begin{array}{l}\text { Fortalecimento das estruturas } \\
\text { operacionais: equipamentos } \\
\text { para auditório }\end{array}$ & $13.264,87$ & 0,00 & $13.264,87$ & $18 / 11 / 1999$ & $30 / 08 / 2001$ \\
\hline $\begin{array}{l}\text { Fortalecimento das estruturas } \\
\text { operacionais: móveis e } \\
\text { material permanente }\end{array}$ & $52.343,31$ & $2.535,54$ & $54.878,85$ & $18 / 11 / 1999$ & $30 / 08 / 2001$ \\
\hline $\begin{array}{l}\text { Fortalecimento das estruturas } \\
\text { operacionais: reforma e } \\
\text { ampliação do anexo II }\end{array}$ & $35.526,46$ & 725,03 & $36.251,49$ & $22 / 02 / 2001$ & $22 / 02 / 2001$ \\
\hline $\begin{array}{l}\text { Instrumental técnico: } \\
\text { equipamentos de medição }\end{array}$ & $21.581,80$ & $1.336,09$ & $22.917,89$ & $18 / 11 / 1999$ & $08 / 08 / 2001$ \\
\hline
\end{tabular}




\begin{tabular}{|c|c|c|c|c|c|}
\hline ambiental & & & & & \\
\hline $\begin{array}{l}\text { B) DER - PB } \\
\text { Estradas }\end{array}$ & $53.459,06$ & $2.411,79$ & $55.870,85$ & 05/06/2000 & $19 / 11 / 2001$ \\
\hline \multicolumn{6}{|l|}{ C) CAGEPA } \\
\hline Capacitação de pessoal & 0,00 & $11.259,15$ & $11.259,15$ & 01/09/1999 & 01/09/1999 \\
\hline $\begin{array}{l}\text { Micromedição (João Pessoa } \\
\text { e Campina Grande) }\end{array}$ & 0,00 & $47.298,63$ & $47.298,63$ & 01/09/1999 & 01/09/1999 \\
\hline $\begin{array}{l}\text { Reengenharia dos processos } \\
\text { comerciais }\end{array}$ & 0,00 & $188.655,52$ & $188.655,52$ & $31 / 08 / 1999$ & 01/09/1999 \\
\hline \multicolumn{6}{|l|}{ D) PBTUR } \\
\hline Capacitação de pessoal & $31.902,56$ & 879,41 & $32.781,97$ & $13 / 12 / 1999$ & $01 / 07 / 2002$ \\
\hline $\begin{array}{l}\text { Fortalecimento das estruturas } \\
\text { operacionais: reforço e } \\
\text { modernização da base } \\
\text { operacional }\end{array}$ & $131.463,73$ & $13.011,32$ & $144.475,05$ & $07 / 12 / 2000$ & $08 / 11 / 2004$ \\
\hline Promoção e divulgação & $76.053,66$ & $15.073,75$ & $91.127,41$ & 18/11/1999 & $10 / 05 / 2002$ \\
\hline $\begin{array}{l}\text { Promoção } \\
\text { folheteria do } \\
\text { Paraíba }\end{array}$ & $7.406,80$ & 0,00 & $7.406,80$ & $18 / 10 / 2000$ & $18 / 10 / 2000$ \\
\hline $\begin{array}{l}\text { Promoção turística: estudos } \\
\text { socioeconômicos e formação } \\
\text { de perfis turísticos }\end{array}$ & $24.143,30$ & $1.023,36$ & $25.166,66$ & $07 / 04 / 2000$ & $05 / 04 / 2001$ \\
\hline $\begin{array}{l}\text { Promoção turística: } \\
\text { formulação de inventários de } \\
\text { oferta turística }\end{array}$ & $12.259,03$ & 70,77 & $12.329,80$ & 18/11/1999 & $30 / 10 / 2001$ \\
\hline $\begin{array}{l}\text { E) Unidade Executora do } \\
\text { PRODETUR no Estado da } \\
\text { Paraíba (UEE - PB) }\end{array}$ & $44.413,61$ & $8.312,61$ & $52.726,22$ & $24 / 01 / 2001$ & $24 / 05 / 2005$ \\
\hline
\end{tabular}

Fonte: Adaptado do Banco do Nordeste - Relatório 02 (2005, p. 26).

Se somarmos os recursos totais do BID destinados ao desenvolvimento institucional no Estado da Paraíba temos o valor de US\$ 886.638,02, sendo o maior valor (US\$ 283.229,08) concedido a PBTUR, o segundo órgão mais beneficiado foi a Superintendência de Administração do Meio Ambiente (SUDEMA) com um recurso de US\$ 267.321,94, apesar de não ter recebido recursos do BID a Companhia de Água e Esgotos da Paraíba (CAGEPA) recebeu a maior contrapartida local no valor de US\$ 247.213,3. De todas as ações de desenvolvimento institucional na Paraíba a única que 
não recebeu contrapartida local alguma foram os planos diretores dos municípios do litoral paraibano.

Apesar dos recursos aplicados pelo PRODETUR na Paraíba no quesito desenvolvimento institucional parecerem volumosos corresponderam a apenas $5,49 \%$ do total, a Paraíba foi o segundo estado que menos recebeu recursos, perdendo apenas para o Piauí com 4,58\% do total. O maior beneficiado foi Alagoas com um percentual 26,31 do total de investimentos.

No que se refere ao segundo componente do programa, infra-estrutura básica/ serviços públicos os principais projetos segundo o Banco do Nordeste - Relatório 02 (2005, p.39) na Paraíba foram nas SES de Ponta de Campina-Poço-Camboinha-Areia Dourada (Cabedelo-PB); Bairro do Bessa (João Pessoa - PB) e nos Bairros de TimbóBancários-Adjacências (João Pessoa - PB). Os recursos do BID se destinaram apenas ao município de Cabedelo somando US\$ 4.064.657,64 correspondendo somente a $4,66 \%$ do total, os outros projetos, referentes a João Pessoa, tiveram unicamente investimentos a nível local. Abaixo podemos observar um quadro com o resumo do investimento no item água/ esgotamento sanitário na Paraíba.

Quadro 14: Infra-estrutura Básica Urbana (Saneamento e Esgoto)

\begin{tabular}{|c|c|c|c|c|c|c|c|}
\hline Projeto & Município & $\begin{array}{l}\text { Rede } \\
(\mathrm{km})\end{array}$ & $\begin{array}{l}\text { Adutoras } \\
(\mathrm{km})\end{array}$ & $\begin{array}{c}\text { Emissários/ } \\
\text { Interceptores } \\
(\mathrm{km})\end{array}$ & $\begin{array}{l}\mathrm{N}^{\mathrm{o}} \\
\mathrm{ETI}\end{array}$ & $\begin{array}{l}\mathrm{N}^{\circ} \\
\mathrm{LDE}\end{array}$ & $\begin{array}{l}\text { PAP } \\
\text { (hab) }\end{array}$ \\
\hline \multicolumn{8}{|l|}{ A) Água } \\
\hline $\begin{array}{l}\text { Complexo Cabo } \\
\text { Branco - SAA }\end{array}$ & $\begin{array}{l}\text { João } \\
\text { Pessoa }\end{array}$ & 0 & 8,03 & 0 & 1 & 1200,8 & 6004 \\
\hline \multicolumn{8}{|l|}{ B) Esgoto } \\
\hline $\begin{array}{l}\text { Intermares - SES } \\
\text { (2) }\end{array}$ & Cabedelo & 15,9 & 0 & 5,06 & 0 & 2359,4 & 11797 \\
\hline Bessa - SES (2) & $\begin{array}{l}\text { João } \\
\text { Pessoa }\end{array}$ & 98,2 & 0 & 6,6 & 0 & 3022,4 & 15112 \\
\hline $\begin{array}{l}\text { Valentina de } \\
\text { Figueiredo - SES } \\
\text { (2) }\end{array}$ & $\begin{array}{l}\text { João } \\
\text { Pessoa }\end{array}$ & 58,78 & 0 & 3,5 & 0 & 3114 & 15570 \\
\hline $\begin{array}{l}\text { Complexo Cabo } \\
\text { Branco - SES (1) }\end{array}$ & $\begin{array}{l}\text { João } \\
\text { Pessoa }\end{array}$ & 10,9 & 0 & 5,06 & 0 & 0 & 0 \\
\hline Pedreira 07 - ETE & $\begin{array}{l}\text { João } \\
\text { Pessoa }\end{array}$ & 0 & 0 & 0 & 1 & 0 & 0 \\
\hline $\begin{array}{lr}\text { Ponta } & \text { de } \\
\text { Campina; } & \text { Poço; }\end{array}$ & Cabedelo & 8,086 & 0 & 9,3539 & 0 & 3419,6 & 17098 \\
\hline
\end{tabular}




\begin{tabular}{|l|c|c|c|c|c|c|c|}
\hline $\begin{array}{l}\text { Areia Dourada - } \\
\text { SES (2). }\end{array}$ & & & & & & & \\
\hline $\begin{array}{l}\text { Timbó; Bancários } \\
\text { e Adjacências - } \\
\text { SES (1). }\end{array}$ & $\begin{array}{c}\text { João } \\
\text { Pessoa }\end{array}$ & 61,06 & 0 & 4,64 & 0 & 5055,2 & 25276 \\
\hline
\end{tabular}

Fonte: Adaptado do Banco do Nordeste - Relatório 02 (2005, p.42).

\begin{tabular}{|l|}
\hline \multicolumn{1}{|c|}{ Legenda do Quadro 14: } \\
$\mathrm{N}^{\mathrm{o}} \mathrm{ETI}$ = Número de Estações de Tratamento de Água Implantadas \\
$\mathrm{N}^{\mathrm{o}} \mathrm{LDE}$ = Número de Ligações Domiciliares Efetivadas \\
$\mathrm{PAP}=$ População Atendida por Projeto \\
$\mathrm{SAS}=$ Sistema de Abastecimento de Água \\
$\mathrm{SES}=$ Sistema de Esgotamento Sanitário \\
$\mathrm{ETE}=$ Estação de Tratamento de Esgotos
\end{tabular}

No subitem esgotamento sanitário a Paraíba detém o segundo melhor resultado no que se refere à extensão (em $\mathrm{km}$ ) de rede de esgoto, com um total de 252,9 km, enquanto a Bahia possui o melhor resultado com $370,5 \mathrm{~km}$, já no item emissários/ interceptores, o Estado possui também a segunda maior extensão (em km) com 34,2 km contra 40 km do Ceará.

Apesar dos investimentos do BID na Paraíba corresponderem apenas 7,04\% do total (US\$ 8.325.378,07) a contrapartida local foi a maior (US\$ 12.369.347,29) entre os Estados participantes do PRODETUR, totalizando um investimento em saneamento de US\$2 20.694.725,36.

Outro subitem que constou na infra-estrutura básica/ urbana foi a construção de rodovias e vias urbanas. Na Paraíba o investimento em infra-estrutura de acesso ocorreu apenas na PB-008, rodovia que liga João Pessoa aos demais municípios litorâneos, e estes entre si. Os trechos da PB-008 contemplados foram os que ligam Tambaba a Acaú (ligação entre os municípios de Conde a Pitimbú) e o Cabo Branco a Jacumã - Tambaba (ligação entre os municípios de João Pessoa ao Conde). Abaixo podemos observar um quadro com as origens dos recursos.

Quadro 15: Recursos Investidos em Rodovias na Paraíba pelo PRODETUR/ NE

\begin{tabular}{|l|c|c|c|c|l|}
\hline \multirow{2}{*}{ Projeto } & \multicolumn{3}{|c|}{ Recursos (em US\$) } & Data inicial & \multicolumn{1}{c|}{$\begin{array}{c}\text { Data final } \\
\text { Desembolso }\end{array}$} \\
\cline { 2 - 6 } Desembolso \\
\hline PB-008: Tambaba, Acaú & $4.383 .472,76$ & $53.394,48$ & $4.436 .867,24$ & $17 / 12 / 1999$ & $07 / 06 / 2002$ \\
\hline $\begin{array}{l}\text { PB-008: Cabo Branco, } \\
\text { Jacumã, Tambaba }\end{array}$ & $5.928 .100,51$ & $38.025,88$ & $5.966 .126,39$ & $28 / 01 / 1999$ & $10 / 10 / 2001$ \\
\hline
\end{tabular}

Fonte: Adaptado do Banco do Nordeste - Relatório 02 (2005, p.62). 
Ao total, os recursos empregados na PB-008 serviram para a construção de 48 km de rodovia entre João Pessoa (Cabo Branco) a Pitimbú (Acaú), correspondendo a $11,57 \%$ do total investido pelo BID neste subitem. Os recursos no quesito transporte ocorrem apenas na rodovia PB-008, não foi destinado nenhum investimento em vias urbanas na Paraíba.

O último subitem de infra-estrutura básica corresponde à recuperação do patrimônio cultural, a participação do programa neste subitem foi questionada pelo próprio Banco do Nordeste - Relatório 01 (2005, p. 25), que afirma o seguinte:

é importante ressaltar que os investimentos do PRODETUR/NE em Recuperação do Patrimônio Histórico muitas vezes complementaram outros investimentos do estado, com utilização de diferentes fontes de recursos (BID / Monumenta, Programa de Recuperação de Sítios Históricos - URBIS, Recursos Próprios), e da própria iniciativa privada.

Apenas os Estados da Bahia, Maranhão e Pernambuco obtiveram uma boa quantidade de investimentos do programa neste item. Sendo assim, sua participação neste quesito, Paraíba, representou pouco impacto. O principal responsável pela recuperação do patrimônio histórico de João Pessoa foi o convênio estabelecido entre Brasil/ Espanha em 1987, culminando na criação da Comissão Permanente de Desenvolvimento do Centro Histórico de João Pessoa.

Assim, a extensão da recuperação de edifícios históricos no Centro Histórico de João Pessoa ficou restrita a duas casas, com uma área total de $1.452 \mathrm{~m}^{2}$. O gasto para a recuperação destes foi de US\$ 327.441,64 pelo BID e mais US\$ 11.372,94 local, totalizando US\$ 338.814,58, um dos menores investimentos neste subitem, sendo maior apenas do que aquele investido no Piauí (US\$ 321.684,04).

O último item do programa, projetos/ estudos, na Paraíba se restringiu a um único projeto, o estudo da viabilidade técnica da rodovia PB-008, no trecho Lucena (Litoral Norte da Paraíba) ao Rio Grande do Norte. Para a realização deste estudo o BID investiu US\$ 145.766,25 com uma contrapartida local de US\$ 4.814,08 totalizando US\$ 150.580,33. Os investimentos do BID neste item na Paraíba totalizaram aproximadamente $6,15 \%$ do total dos recursos, o Estado foi o terceiro maior beneficiado neste item, o Estado que recebeu mais recursos foi o Ceará. 


\section{3 - Análise dos Resultados Apresentados}

$\mathrm{O}$ item desenvolvimento institucional apesar de beneficiar com maior parcela dos recursos a PBTUR, acabou por servir para compra de materiais diversos e treinamento de pessoal na SUDEMA também. Mesmo percebendo a íntima relação que existe entre turismo e meio ambiente e as razões para que o programa não seja voltado exclusivamente para órgãos de turismo nos parece exorbitante investir em equipamentos diversos (de informática, para auditórios, móveis e matérias permanentes) para a SUDEMA a quantia de US\$ 108.441,76, enquanto para alguns estudos (inventários da oferta, perfil do turista) que são essenciais para o planejamento do turismo sejam investidos apenas US\$ 36.402,33, assim como o valor repassado a SUDEMA nos parece muito elevado se comparado ao investido em comunicação turística (folheterias e divulgação) US\$ 83.460,46 pela PBTUR. Apenas no quesito móveis e materiais permanentes, para a SUDEMA, foram gastos mais de US\$50.000.

A cidade de João Pessoa, apesar de ser a mais importante cidade da Paraíba não dispõe de estudos básicos, como os inventários da oferta ${ }^{14}$ e demanda turísticos, para o planejamento do turismo. Se a capital possui poucos estudos para o planejamento do turismo, os municípios localizados no Litoral Norte e Sul da Paraíba possuem condições ainda mais precárias, uma total ausência de dados que inviabiliza a elaboração de um plano municipal de turismo baseado em fontes concretas. Assim, acreditamos que caberia ao PRODETUR/ NE investir também na formação (já que não existem tais órgãos na maioria dos municípios litorâneos) ou desenvolvimento de bases institucionais para alguns dos principais municípios litorâneos (a exemplo do Conde Litoral Sul e possivelmente Cabedelo - Litoral Norte). Na mesorregião da Zona da Mata Paraibana, Cabedelo é o município mais importante (tanto em termos econômicos pela presença do porto quanto turísticos) depois da capital, no entanto, até dezembro de 2004 (segundo pesquisa realizada pela autora in loco durante trabalho de conclusão de curso de graduação), este município não possuía nenhum estudo relacionado ao turismo (número de turistas, inventários, perfis, número de cruzeiros recebidos, entre outros.) e as condições físicas e de pessoal da secretaria municipal de turismo de Cabedelo eram extremamente precárias.

Acreditamos que o programa poderia investir na capacitação de órgãos municipais de turismo na Paraíba, assim como investir somas maiores em ações

\footnotetext{
${ }^{14}$ Atualmente a SETUR/ JP está realizando um inventário da oferta turística.
} 
voltadas para promoção e marketing de modo semelhante ao ocorrido com o Maranhão, onde foi investido, neste item, pelo BID US\$ 1.001.080,06, e no item elaboração de plano de marketing US\$2.079.822,30.

Os órgãos municipais de turismo da Paraíba se encontram amplamente fragilizados e o programa deveria olhar mais atentamente para estes, auxiliando-os em sua capacitação profissional e na elaboração de estudos, ao invés de investir uma pequena soma na PBTUR e esquecer dos demais.

Os resultados obtidos com os investimentos em infra-estrutura, em especial esgotamento sanitário, ao nosso ver, foi um dos pontos mais positivos do programa, correspondendo a um número de 16.971 ligações domiciliares a terceira maior, depois da Bahia e do Maranhão. Assim como a extensão da rede coletora de emissários/ interceptores de esgoto, constituindo o segundo estado mais beneficiado. No entanto, devemos fazer algumas colocações sobre este item. Percebemos um claro desejo do programa de investir em infra-estrutura no Complexo Cabo Branco, o PRODETUR/NE foi criado como um instrumento para tornar possível a efetivação dos megaprojetos, e os investimentos em infra-estrutura no Cabo Branco deixam isso bem claro. Apesar de já ter sido amplamente discutida a ineficiência de megaprojetos parece haver uma insistência do programa em incentivar o desenvolvimento de um modelo de desenvolvimento turístico já ultrapassado e pouco sustentável.

O próprio relatório do TCU - Parte 02 (2005, p.37) deixa claro o desperdício de verba que houve no local, segundo este:

o sistema de esgotamento sanitário do Complexo Cabo Branco/PB foi construído em região desabitada visando atrair investimentos estrangeiros no setor do turismo, que não se confirmaram. Nesse contexto, a obra não foi concluída e os investimentos realizados sofrem processo de deterioração e depredação.

Além destes recursos investidos no Cabo Branco terem se perdido, também questionamos o discurso do programa que afirma que os investimentos beneficiarão principalmente a população de baixa renda, será que investir em locais desabitados para atrair investimentos estrangeiros é beneficiar a população de baixa renda?

O modelo de desenvolvimento turístico que visa atrair capital estrangeiro em megaempreendimentos tem se mostrado em muitos casos pouco eficaz para a população local. Devemos, no entanto, enfatizar que a entrada de investimento estrangeiro na Paraíba, especialmente em pequenos empreendimentos já trouxe grandes benefícios para o turismo. Como exemplo desta afirmação, podemos citar as várias pousadas 
(Pousada Viking, Pousada Arco-íris, Pousada Portal do Sol, entre outras) presentes no litoral do Conde que são de propriedade de estrangeiros, uma delas (Pousada Viking) foi uma das primeiras pousadas construídas no município do Conde, sua construção possibilitou o pernoite de turistas nesta região.

Outro item que parece corroborar a afirmação de que o PRODETUR visava atrair investimentos para incentivar o megaprojeto do Complexo Cabo Branco, é o investimento exclusivamente na PB-008 trecho Cabo Branco (João Pessoa) a Acaú (Pitimbú). Como o município de Pitimbú faz a divisa entre Paraíba e Pernambuco a principal intenção do projeto é não só 'turistificar ${ }^{15}$, o Litoral Sul, mas também facilitar o acesso entre Pernambuco e o Bairro do Cabo Branco (João Pessoa) local do megaprojeto da Paraíba.

Atualmente as praias de Ponta de Campina e Areia Dourada, em Cabedelo, vem se destacando pela construção de condomínios residenciais de alto padrão. Recentemente, em setembro de 2007, foi inaugurado um condomínio de luxo na beiramar da praia de Ponta de Campina denominado de 'Varandas do Atlântico'. O condomínio possui estrutura de resort, com mais $1.200 \mathrm{~m}^{2}$ de área de piscina, cascata artificial, sauna, hidromassagem, fitness, bar molhado entre outros. $\mathrm{O}$ empreendimento corresponde a uma área total de $11.000 \mathrm{~m}^{2}$. O valor para compra dos apartamentos varia, em média, entre quatrocentos e cinqüenta mil a um milhão e cem reais. Aproximadamente um ano antes da construção deste último foi inaugurado na beira mar da mesma praia o 'Residencial Morada do Atlântico' com uma estrutura semelhante ao primeiro, mas numa área mais reduzida, de aproximadamente $6.000 \mathrm{~m}^{2}$. O valor que este último está sendo comercializado atualmente varia de trezentos e oitenta e cinco mil reais a aproximadamente oitocentos mil reais. Tanto o 'Varandas do Atlântico' quanto o 'Morada do Atlântico' são empreendimentos de uma construtora potiguar denominada Alliance.

Com relação à construção da rodovia PB-008 entendemos que esta foi uma medida essencial sob o ponto de vista da provisão de um bem público que havia sido negligenciado pelos Governos (Estadual, Municipal e Federal) e que o programa mesmo que por uma outra intenção acabou por favorecer as comunidades de pescadores que moram (ou moravam, já que em decorrência da especulação imobiliária muitos destes

\footnotetext{
${ }^{15}$ Segundo Fratucci (2006, p. 03) o processo de turistificação corresponde a uma forma de apropriação do espaço pelo turismo. Esta 'apropriação', de acordo com Knafou (2001, p. 70) pode ocorrer através de três agentes: mercado, planejadores e os turistas. Sendo citado o mercado como principal agente atual de turistificação.
} 
abandonaram suas casas) na localidade. A PB-008 fez até mesmo, com que o transporte coletivo chegasse a algumas localidades antes esquecidas, tamanha era a precariedade de acesso. Mas sua construção gerou vários impactos no local.

Sobre a construção da PB-008 e seus impactos ambientais, o relatório do TCU Parte 02 (2005, p.39) afirma que:

[...] pode-se inferir que o passivo ambiental provocado diretamente pelo PRODETUR/ NE I resulta do processo construtivo de projetos de engenharia - desmatamento, exploração de jazidas, geração do entulho de obras, consumo de recursos naturais. Mesmo nestes casos houve cuidados para mitigar os impactos negativos dessas obras no meio ambiente. Na Paraíba, por exemplo, o trajeto da rodovia PB-008 foi alterado para preservar os manguezais da região e utilizou técnica construtiva que requer menos desmatamento.

Apesar de segundo o TCU terem sido utilizadas técnicas de construção mais responsáveis em termos ambientais, Guedes (2005, p.04) afirma que a construção da PB-008 no Litoral Sul da Paraíba trouxe como conseqüência uma ocupação desordenada que nem ao menos respeita a legislação ambiental vigente. Deste modo, apesar de ser louvável a busca por formas de construção ambientalmente responsáveis acreditamos que pouco foi o resultado final desta ação se posteriormente a ocupação desordenada do local acarretou num grande impacto ambiental.

Antes mesmo da construção da rodovia já haviam sido relatados problemas ambientais graves, segundo Guedes (2005, p.29), a situação urbana da praia do Jacumã pode ser descrita da seguinte forma:

\footnotetext{
No geral a ocupação é mais grave ao longo das vias de acesso a praia e ao redor do sistema lagunar. Na planície litorânea existem algumas construções simples destinadas exclusivamente a atender o turismo e o lazer, sendo que as mesmas não dispõem de infra-estrutura funcional adequada. Nesse local é freqüente o acúmulo de lixo deixado por estabelecimentos comerciais, bem como por turistas que visitam a área. Nos finais de semana e, particularmente durante o verão, a quantidade de pessoas que afluem a área é muito grande o que, certamente, contribui para agravar os problemas ambientais. Constatouse durante a realização desta pesquisa que existem ligações clandestinas de esgoto para o interior do sistema lagunar. (op.cit.)
}

Devemos observar que se o programa possuía a intenção de preservar ambientalmente a área, deveria, antes da construção da rodovia, solucionar os problemas ambientais da região já existentes. Ao invés de construir uma rodovia que aumentou o fluxo de pessoas para uma região já 'fragilizada'. Também não podemos deixar de colocar novamente a necessidade de investimentos nos órgãos municipais de turismo, concedendo a estes em conjunto com outros órgãos, a necessidade de elaboração de projetos para uma ocupação turística de forma racional, respeitando a atual legislação ambiental. 
Não existe nenhuma forma de acompanhamento dos impactos advindos das ações efetuadas pelo PRODETUR ${ }^{16}$, ao menos não em termos ambientais, sociais e culturais. Investimentos efetuados por si só, sem um acompanhamento constante, podem se perder ou trazer malefícios que não ocorreriam se existisse um acompanhamento constante com possibilidade de atuações corretivas.

Outro subitem presente no tópico de infra-estrutura é a recuperação de patrimônio histórico. Como já foi apresentado, anteriormente, na Paraíba o programa contribuiu apenas para a recuperação de duas casas no centro histórico da cidade de João Pessoa. O maior responsável pela recuperação do centro histórico ${ }^{17}$ da capital paraibana é o convênio Brasil - Espanha.

As ações do PRODETUR na recuperação do centro histórico surtiram pouco efeito no resultado final do projeto de recuperação do centro histórico, mesmo tendo tido pouco efeito entendemos que o projeto foi positivo, mas devemos considerar a colocação de uma ação de recuperação pelo programa e não de revitalização. Para o desenvolvimento do turismo no centro histórico de João Pessoa nos parece mais correto a adoção de medidas de revitalização ${ }^{18}$ e não exclusivamente de recuperação.

Segundo Pires (2001, p.06) a restauração/ recuperação pode ser entendida como “uma intervenção física no bem histórico de forma que mantenha sua integridade. A restauração ocorre como uma intervenção drástica visando a objetivos que se alteram do essencial, que é manter de pé certa edificação ou localidade, até restabelecer suas características o mais próximos possível da obra original". Já o processo de revitalizar também engloba dar uso ao elemento histórico recuperado.

Para fiz turísticos pouco adianta recuperar uma edificação vazia. Os programas de revitalização dos centros históricos de Salvador e Recife além de restaurar as edificações antigas também deram uso a estas, que se transformaram em lojas de

${ }^{16}$ O relatório do TCU - Parte 03 (2005, p.70) afirma que na segunda fase do programa será criado o Programa de Desenvolvimento do Turismo Sustentável (PDTIS) com a intenção de mitigar possíveis dados ambientais causados pelo PRODETUR/NE em sua primeira fase.

17 Acreditamos que os investimentos no Centro Histórico da cidade de João Pessoa aumentaram substancialmente, já que este foi recentemente (em dezembro de 2007) considerado patrimônio histórico e artístico nacional pelo IPHAN.

${ }^{18}$ O atual prefeito de João Pessoa, Ricardo Coutinho, lançou em abril de 2007 em conjunto com a Secretaria de Desenvolvimento Urbano, o programa de revitalização do Bairro do Varadouro (um dos bairros que faz parte do centro histórico), este programa pretende instalar a população de baixa renda que não tem residência nas casas que já foram restauradas pelo convênio Brasil - Espanha no bairro do Varadouro. Mas as casas reconstruídas em outras localidades ainda estão sem utilização, a exemplo de algumas casa da Figura 25 na Praça Antenor Navarro, um dos principais atrativos do Centro Histórico de João Pessoa. 
souvenirs, restaurantes, bares, habitações populares, dentre outros. Apenas a fachada dos casarios recuperada consiste em um atrativo de pouco uso para os turistas, apenas uma parada de poucos minutos, para fotografar, em meio a um city tour. Dar um uso ao local é o que o torna um atrativo turístico de verdade.

No programa de recuperação do centro histórico de João Pessoa (tanto no que se refere às contribuições dadas pelo PRODETUR como pelo convênio Brasil e Espanha) se destacam as ações efetuadas no Hotel Globo, na Praça Antenor Navarro e na Fábrica de Vinhos Tito Silva.

Figura 25: Praça Antenor Navarro - Centro Histórico de João Pessoa/ PB

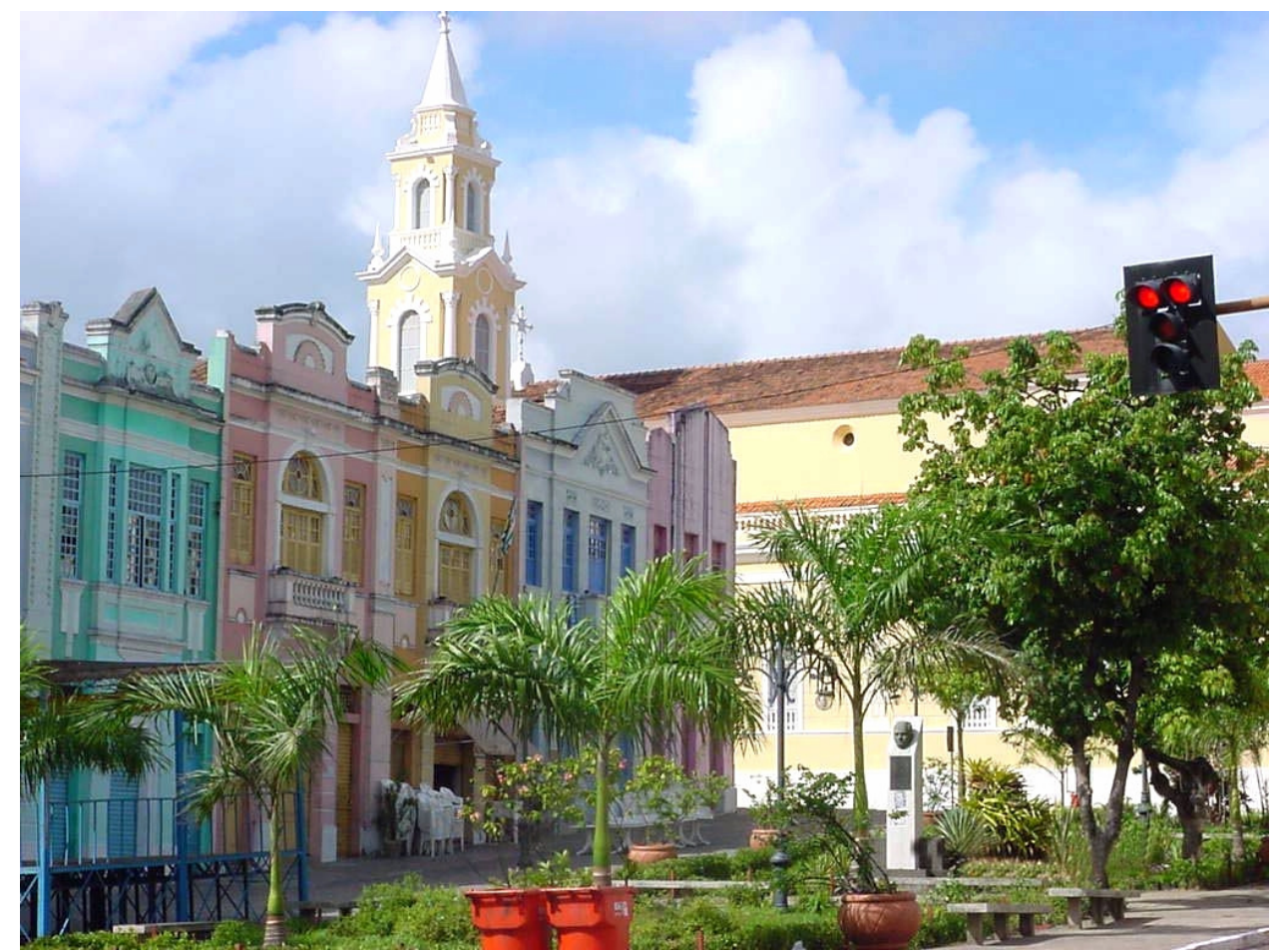

Fonte: Ricardo Paulo - CD turístico: Guia turístico da cidade de João Pessoa (2001).

Ainda há muito por ser feito no centro histórico de João Pessoa, é grande a quantidade de edificações históricas que não passou por ação alguma de restauração. A poucos metros da Praça Antenor Navarro existe grande quantidade de edificações em processo avançado de degradação pela ação do tempo. Deste modo, observamos que o PRODETUR poderia atuar de modo mais consistente em um programa com a finalidade de realizar uma revitalização do centro histórico de João Pessoa, atuando conjuntamente com o convênio Brasil - Espanha.

O último item do PRODETUR se refere à elaboração de estudos/ projetos que pudessem ser alvo de implementação pelo programa em um momento futuro. Na Paraíba, o único estudo realizado foi o da PB-008 no trecho que liga Lucena ao Rio 
Grande do Norte. O percurso que faz a ligação entre este trecho é de fato muito precário, a possível efetivação desta ação poderia representar um aumento no número de turistas do Rio Grande do Norte visitando o Litoral Norte, de modo semelhante ao que ocorreu na construção da via que liga Pitimbú as demais praias do Litoral Sul e a João Pessoa.

Também nos parece muito tímida a participação do estado com apenas um estudo, já que a intenção era realizar estudos que pudessem ser efetivados num momento futuro poderia ser tirado o foco apenas da região litorânea, em especial do megaprojeto do Cabo Branco, e haver uma diversificação em estudos/ projetos compreendendo outras regiões do Estado próximas a capital, como por exemplo, Campina Grande que já apresenta relativo fluxo de turistas e uma ampla infra-estrutura hoteleira, ou mesmo, ser pensado em projetos de inclusão de localidades próximas a João Pessoa e Campina Grande que ainda não dispõem de grande infra-estrutura, mas que possuem recursos (ambientais/ culturais), tais como os municípios de Areia, Pirpirituba, Ingá, Massaranduba, dentre outros, iniciando assim uma diversificação do turismo na Paraíba e uma integração entre os eixos litorâneos e interioranos. Segundo Machado (1997, p. 206) para o desenvolvimento do turismo na Paraíba é necessário integrar os dois eixos: “o litorâneo, baseado no modelo 'sol e praia', típico dos mercados turísticos globalizados; e o interior, valorizando seus atrativos turísticos naturais, bem diferentes dos do litoral, assim como seu folclore, seu artesanato, suas festas religiosas e suas comidas típicas; manifestações culturais tão presentes no interior do estado".

A concentração de investimentos a nível espacial do programa ficou muito clara. A Paraíba possui uma área total de $56.439,838 \mathrm{~km}^{2}$ e os investimentos do programa compreenderam uma área de apenas $1.331 \mathrm{~km}^{2}$ (soma das áreas dos municípios contemplados: Baía da Traição - $102 \mathrm{~km}^{2}$; Rio Tinto - $466 \mathrm{~km}^{2}$; Marcação - $123 \mathrm{~km}^{2}$; Lucena - $89 \mathrm{~km}^{2}$; Cabedelo - $31 \mathrm{~km}^{2}$; João Pessoa - $211 \mathrm{~km}^{2}$; Conde $-173 \mathrm{~km}^{2} \mathrm{e}$ Pitimbú - $136 \mathrm{~km}^{2}$ ) o que corresponde a aproximadamente $2,35 \%$ da área total do estado. Nesta pequena área, no entanto, habitam aproximadamente 22,23\% da população total da Paraíba. Assim, entendemos que o PRODETUR/ PB trouxe 'benefícios' para uma área ínfima do estado, inferior a 2,5\% onde mora (menos de 23\%) da população mais privilegiada do estado. 


\section{CONSIDERAÇÕES FINAIS}

A infra-estrutura é um componente integrante e fundamental do SISTUR, sendo inclusive decisivo para o processo de construção de um atrativo turístico, representando um dos elementos definidores do grau de atratividade de uma destinação turística. A presença deste elemento fundamental ao SISTUR também é grande definidor da qualidade de vida de uma população. Sendo assim, a construção de infra-estrutura básica urbana representa grande papel para o desenvolvimento social e econômico de uma cidade.

Com base no argumento de que as cidades nordestinas possuíam recursos (naturais e culturais) para desenvolver o seu turismo, mas que não disponibilizavam de infra-estrutura e verba, e também frente ao apelo de desenvolvimento sócio-econômico que a implantação de infra-estrutura e o turismo podem gerar, o PRODETUR foi criado. Apesar de sua criação aparentar uma ação voltada prioritariamente para o desenvolvimento sócio-econômico de localidades pobres, na verdade o programa foi criado com a intenção de atrair investimentos de grandes grupos hoteleiros para estas localidades.

Ou seja, repetiam-se modelos de turismo que já foram conhecidamente considerados de pouco impacto para o desenvolvimento da população autóctone. Além disso, este pressuposto vai contra a atual vertente de atuação do MTUR que apregoa uma desconcentração e uma 'viagem de inclusão' (Plano Nacional de Turismo 2007 2010) da atividade turística.

A necessidade da criação de políticas públicas surge a partir da constatação de que o mercado apresenta falhas. Dentre estas está a provisão de bens públicos. O PRODETUR atuou fornecendo bens públicos tais como rodovias, esgotamento sanitário, abastecimento de água, dentre outros. No entanto, no caso específico da Paraíba, parte destes bens públicos não foram construídos com a intenção de privilegiar os interesses da população autóctone, mas com a finalidade de atrair investimento de capital externo.

Em determinadas localidades, o PRODETUR atuou apenas como um facilitador do processo de urbanização de praias que se transformaram em residências de luxo para os habitantes mais abastados de João Pessoa e para veranistas de estados vizinhos. Auxiliando na especulação imobiliária, na privatização mascada de partes do litoral e no enriquecimento de grandes construtoras. 
Quando grandes construtoras, a exemplo da Alliance, constroem megaempreendimentos, como os citados anteriormente, acabam por causar impactos ambientais, já que invadem parte da faixa litorânea (que a rigor seria área de marinha) e delimitam uma área da praia como sendo considerada privativa para os condôminos ${ }^{19}$.

O papel mais importante do Governo, que atua por meio de políticas públicas, é defender o interesse público. Quando este atua favorecendo interesses individuais também incorre em uma grave falha de gestão pública.

Assim, percebemos que o programa na Paraíba poderia ter atuado no incentivo de roteiros turísticos alternativos (a exemplo dos enunciados no anexo III), o que significaria uma nova atividade produtiva para estas cidades.

Devemos esclarecer que o turismo não é caracterizado como sendo um deslocamento de grande afluxo de pessoas para áreas de atratividade internacional. A atividade turística também pode ser realizada em atrativos que possuam uma baixa hierarquia, ou seja, que atraiam pessoas que habitam nas redondezas daquele município. No caso específico da Paraíba, roteiros alternativos para o interior podem atrair a população de João Pessoa, Cabedelo, Campina Grande, Recife, Olinda, Parnamirim, Natal, entre outros. Representando um passeio de final de semana, por exemplo, para os habitantes destas cidades que buscam tranqüilidade, não dispõem de muito tempo para viajar e procuram algo diferente dos convencionais roteiros de praia.

Acreditamos também que caberiam mais pesquisas no interior paraibano para criar roteiros semelhantes aos Caminhos do Frio e os Caminhos do Padre Ibiapina/ Caminhos do Engenho (ver anexo III) da mesma forma que pensar de que modo o PRODETUR poderia incentivar o desenvolvimento de tais roteiros por meio de ações de marketing, capacitação profissional, investimento na formação/ qualificação de estruturas institucionais de turismo nestes municípios, incentivo à criação de arranjos produtivos locais (APL), concedendo incentivos fiscais, com a construção de infraestrutura básica urbana, como empreendedor direto de infra-estrutura turística, criando/ promovendo eventos que enfatizassem a cultura local ou apenas como coordenador no fortalecimento do trade turístico dos municípios.

\footnotetext{
${ }^{19}$ Não existe uma cerca ou qualquer delimitação feita por materiais. Mas a posição das construções dificulta o acesso a praia de outras pessoas que não aquelas que residem nestes condomínios. Além de que, em certos casos, a área litorânea 'delimitada' como particular passa a ser atentamente observada por vigias que tratam de preservar a integridade dos condôminos contra qualquer ameaça externa.
} 
Destacamos a intenção do MTUR de promover uma desconcentração do turismo no Brasil $^{20}$. Como já observamos o turismo em nível global e até mesmo nacional se encontra extremamente concentrado em poucas localidades que são caracterizadas por grandes receptoras de um turismo de massa (destacando a nível nacional o Sudeste, e o Nordeste, em especial Salvador) e grandes emissores (Sudeste). Com base no argumento da desconcentração entendemos que os investimentos e ações do programa deveriam privilegiar localidades fora destes eixos de concentração. Mas, com relação unicamente a região Nordeste, o que se percebeu nas ações do PRODETUR em sua primeira fase foi justamente o oposto.

No entanto, não podemos deixar de destacar que esta política pública teve início no ano de 1994 e concluída sua primeira fase em 2005. Este período compreende grandes mudanças no modo de pensar o desenvolvimento do turismo. Assim, possivelmente parte dos projetos implementados pelo programa foram planejados há mais de dez anos atrás, quando ainda predominava em todos os meios uma visão de um modelo de desenvolvimento do turismo baseado em grandes empreendimentos hoteleiros. Atualmente os modelos de desenvolvimento apregoados, ao menos nos meios acadêmicos, são aqueles baseados na participação endógena, desenvolvimento local/ territorial, e também em segmentos e nichos de mercado como o turismo rural, sertanejo, cultural, ecoturismo, entre outros, que possuem em seu escopo a inserção da população local gerando benefícios para esta.

Em razão desta 'nova percepção', ao menos dos teóricos do turismo, mas não necessariamente dos nossos governantes, com relação a modelos de desenvolvimento do turismo e até mesmo em decorrência da posição do MTUR em seu PNT 2007 - 2010 acreditamos que o PRODETUR/ NE em sua segunda fase possa atuar em cidades do interior nordestino tentando promover uma maior inclusão destas localidades no turismo e no desenvolvimento sócio-econômico.

No entanto, a nosso ver, a verdadeira 'viagem de inclusão' só seria realizada se os investimentos do programa privilegiassem justamente aqueles estados brasileiros do Nordeste que apresentam fluxos turísticos ainda pouco significativos, a exemplo da Paraíba, através de modelos alternativos de desenvolvimento turístico. De nada adianta, se ocorrer uma desconcentração dos investimentos do litoral para o interior repetindo no interior o modelo de desenvolvimento turístico adotado pelo litoral. Devem ser adotadas

\footnotetext{
${ }^{20}$ Ao menos em termos teóricos é o que discorre o PNT 2007-2010, ainda não sabemos se o discurso utilizado no documento vai de fato se concretizar.
} 
novas medidas de gestão do turismo no interior, tendo como base o incentivo ao capital produtivo local.

Acreditamos que o turismo pode sim ocorrer em localidades pouco desenvolvidas, desde que exista um investimento numa infra-estrutura local e na qualificação da população autóctone. Devemos enfatizar que a maioria destas localidades necessitam urgentemente de infra-estrutura e qualificação, para que possam pensar no turismo como uma atividade produtiva. Contrariamente ao que apregoam determinados teóricos do turismo que afirmam que pequenos municípios do interior paraibano e pernambucano já podem ser tratados como destinos turísticos prontos ${ }^{21}$, entendemos que estas localidades ainda têm um grande caminho a percorrer para que possam ser consideradas 'prontas'.

Apesar do PRODETUR/ NE em sua segunda fase estar tomando novos caminhos em direção ao interior, a exemplo do que ocorre na Bahia. A realização do estudo de viabilidade técnica da PB-008 no trecho de Lucena ao Rio Grande do Norte nos faz crer que na Paraíba provavelmente não ocorrerá está mesma desconcentração, ao menos em termos espaciais. Possivelmente, a intenção do programa seja a de fazer no Litoral Norte da Paraíba a mesma ligação rodoviária que foi feita no Litoral Sul, e determinados municípios litorâneos ou da RMJP, a exemplo de Mataraca, Santa Rita e Bayeux, que não foram contemplados na primeira fase o serão na segunda.

Delimitar a importância do PRODETUR/ NE para o turismo na Paraíba é tarefa difícil. Apesar de ter ocorrido um aumento no número de turistas visitando o estado, como podemos afirmar que os investimentos do PRODETUR foram os responsáveis por isso? Ao nosso ver o programa falhou duplamente, primeiro quando apostou no modelo de desenvolvimento baseado em megaempreendimentos hoteleiros e segundo quando não conseguiu atrair o capital externo que tanto desejava e que cria ser necessário para o desenvolvimento do turismo e beneficio da população local do Nordeste. Mas não podemos execrar totalmente o programa em decorrência disso. A idéia de prover núcleos receptores do Nordeste de infra-estrutura básica/ urbana deve ser elogiada e servir de exemplo para a elaboração de futuras políticas públicas voltadas ao turismo. Ainda existem muitas pessoas que acreditam que basta existir uma praia para desenvolver o turismo e não procuram enxergar o turismo como uma atividade sistêmica e complexa que necessita da integração de vários agentes para ser explorada.

\footnotetext{
${ }^{21}$ Para maiores informações ver SEABRA, Giovanni. Turismo Sertanejo. João Pessoa, PB: Editora UFPB, 2007.
} 
O PRODETUR/NE foi a primeira política pública que de fato levantou a questão da importância da infra-estrutura para o turismo. Assim, o programa pode ser considerado inovador e importante sobre este aspecto.

Concluindo, aconselhamos a elaboração de futuros estudos que discorram sobre as ações efetivas no PROECOTUR. Procurando analisar se no 'PRODETUR da Amazônia' ocorreu a mesma dinâmica, em termos de concentração espacial, que no PRODETUR/NE. Se nesta também foi enfatizada a construção de megaempreendimentos hoteleiros, com 'privatizações' de locais públicos e traçar comparações entre os modelos desenvolvidos no Nordeste e na Amazônia. Estas comparações podem inclusive trazer contribuições para o desenvolvimento do turismo em áreas não litorâneas do Nordeste, investindo, por exemplo, em uma maior utilização das UC's nordestinas e nos resquícios de Mata Atlântica como atrativos turísticos e instrumentos de diversificação do produto turístico da Paraíba e de todo Nordeste. Da mesma forma nos pareceria interessante realizar pesquisas sobre a influência de políticas públicas de turismo 'ditas' participativas/ descentralizadoras, a exemplo do PNMT e do PRT - Roteiros do Brasil, para o desenvolvimento de localidades pobres do Nordeste e do Norte. Levantando as metodologias adotadas para a participação da população autóctone e analisando se realmente o discurso utilizado quando da elaboração do programa é cumprido na prática, e se existem canais eficientes para ouvir toda a população local ou se apenas pequenos grupos da comunidade têm voz ativa. 


\section{REFERÊNCIAS BIBLIOGRÁFICAS}

AGUIAR, Geraldo Medeiros. Turismo, desenvolvimento local e integração regional. In: SEABRA, Giovanni (organizador). Turismo de base local: identidade cultural e desenvolvimento regional. João Pessoa, PB: Editora Universitária UFPB, 2007.

AMADO, Adriana; MOLLO, Maria de Lourdes Rollemberg. Noções de macroeconomia: razões teóricas para as divergências entre os economistas. Barueri, SP: Editora Manole, 2003.

BEM, Arim Soares do. A Dialética do Turismo Sexual. Campinas, SP: Papirus, 2005. - (Coleção Turismo).

BENI, Mário Carlos. Análise Estrutural do Turismo. $3^{\text {a }}$ Edição. São Paulo, SP: Editora SENAC SP, 2000.

Política e Planejamento de Turismo no Brasil. São Paulo, SP: Editora Aleph, 2006. (Série Turismo).

BOUlLÓN, Roberto C. Planejamento do Espaço Turístico. Caxias do Sul, RS: Editora EDUSC, 2002.

CANO, Wilson; GUIMARÃES NETO, Leonardo. A questão regional no Brasil: traços gerais de sua evolução histórica. Revista Iberoamericana, Revista de Economia Política, Desarrollo Regional: nuevos desafios, Madrid, 1986.

CARLOS, Ana Fani Alessandri. O turismo e a produção do não-lugar. In YÁZIGI, Eduardo; CARLOS, Ana Fani Alessandri; CRUZ, Rita de Cássia Ariza (organizadores). Turismo: espaço, paisagem e cultura. São Paulo, SP: Editora Hucitec, 1996.

CARVALHO, Fernando J. Cardim de. Mercado, Estado e teoria econômica: uma breve reflexão. Rio de Janeiro: Econômica (Revista da Pós-Graduação em Economia da Universidade Federal Fluminense). Volume 1, Nº 1, Junho de 1999.

Disponível em: http://www.uff.br/cpgeconomia/v1n1/cardim.pdf

Acessado em 14 de setembro de 2007.

CORIOLANO, Luzia Neide Menezes Teixeira. O Turismo nos Discursos, nas Políticas e no Combate à Pobreza. São Paulo, SP: Editora Annablume, 2006.

CRUZ, Rita de Cássia. Política de turismo e território. São Paulo, SP: Editora Contexto, 2001.

Introdução à Geografia do Turismo. São Paulo, SP: Editora ROCA, 2003.

DIAS, Reinaldo. Planejamento do Turismo: política e desenvolvimento do turismo no Brasil. São Paulo, SP: Editora Atlas, 2003. 
DIAS, Reinaldo; CASSAR, Maurício. Fundamentos do Marketing Turístico. São Paulo, SP: Editora Person Prentice Hall, 2005.

DELGADO, Anna Karenina Chaves. A inserção do porto de Cabedelo nos roteiros de cruzeiros marítimos nacionais e mundiais. Trabalho de Conclusão de Curso em Turismo - Planejamento Turístico, João Pessoa, PB: UFPB, 2004.

A qualidade no atendimento dos serviços de alimentação em João Pessoa. Trabalho de Conclusão de Curso em Turismo - Marketing Turístico, João Pessoa, PB: UFPB, 2006.

ENDRES, Ana Valéria. Planejamento Estatal: do centralizado ao participativo e seus reflexos no planejamento do turismo no Nordeste. In: Turismo em Análise, São Paulo, SP: Editora Hucitec, Maio, 2002.

FRANK, Robert H.. Microeconômica e Comportamento. 3. ed. Lisboa: Editora Mcgraw-Hill, 1997.

FRATUCCI, Aguinaldo César. Processos de Turistificação dos Espaços. Seminários de Campo Temáticos 2006 da Universidade Federal Fluminense - UFF.

Disponível em: www.uff.br/posgeo/modules/xt_conteudo/index.php?id=19

Acessado em 03 Abril de 2007.

Governo do Estado da Paraíba (Tarcísio Burity). Guia da Paraíba, 1985.

GUEDES, Joelma Abrantes. Empreendimentos turísticos e impactos ambientais no Distrito de Jacumã, município do Conde - PB. Dissertação de Mestrado do Programa de Desenvolvimento do Meio Ambiente - PRODEMA da Universidade Federal da Paraíba, Campus I, 2005.

Disponível em: http://www.ifremer.fr/avano/notices/00103/641.htm

Acessado em 07 de setembro de 2007.

KNAFOU, Remy. Turismo e território: para um enfoque científico do turismo. In RODRIGUES, Adyr A. Balastreri (organizadora). Turismo e Geografia. Reflexões teóricas e enfoques regionais, São Paulo, SP: Editora Hucitec, 2001.

KOTLER, Philip; HAIDER, Donald H.; REIN, Irving. Marketing Público: como atrair investimentos, empresas e turismo para cidades, regiões, estados e países. São Paulo, SP: Makron Books, 1994.

LAGE, Beatriz Helena Gelas; MILONE, Paulo César. Economia do Turismo. Campinas, SP: Editora Papirus, 1996. (Coleção Turismo).

Impactos socioeconômicos globais do turismo. In LAGE, Beatriz Helena Gelas Lage; MILONE, Paulo César (organizadores). Turismo: teoria e prática. São Paulo, SP: Editora Atlas, 2000.

MACHADO, Marcello de Barros Tomé. Integração entre os eixos turísticos do Estado da Paraíba. In: RODRIGUES, Adyr Balastreri (organizadora). Turismo. Modernidade. Globalização. São Paulo, SP: Editora Hucitec, 1997. 
MOLINA, Sérgio; RODRIGUEZ, Sérgio. Planejamento Integral do Turismo. Caxias do Sul, RS: Editora EDUSC, 2001.

OMT. Guia de Desenvolvimento do Turismo Sustentável. Porto Alegre, RS: Editora Bookman, 2003.

Introdução ao Turismo. São Paulo, SP: Editora Roca, 2001.

OURIQUES, Helton Ricardo. A Produção do Turismo: fetichismo e dependência. Campinas, SP: Editora Alínea, 2005.

PASSOS, Luciana Andrade dos. Paisagem Natural, Patrimônio Cultural e Turismo nos Cariris Paraibanos. Dissertação de Mestrado do Programa de Desenvolvimento do Meio Ambiente - PRODEMA da Universidade Federal da Paraíba, Campus I, 2002. Disponível em: http://201.2.114.147/bds/BDS.nsf/6925A100E6FE1F9C032570120058 A 762/\$File/ NT000A8A06.pdf

Acessado em 25 de setembro de 2007.

PETROCCHI, Mário. Marketing para Destinos Turísticos. São Paulo, SP: Editora Futura, 2004.

PIRES, Mário Jorge. Lazer e Turismo Cultural. Barueri, SP: Editora Manole, 2001.

PORTUGUEZ, Anderson Pereira. Agroturismo e Desenvolvimento Regional. São Paulo, SP: Editora Hucitec, 2ª Edição, 2002.

RUSCHMANN, Doris. Marketing Turístico: um enfoque promocional. Campinas, SP: Editora Papirus, 1995.

TEXEIRA, Aloísio. Mercado e Imperfeições de Mercado: o caso da assistência suplementar.

Disponível em: http://www.ans.gov.br/portal/upload/forum_saude/objeto_regulacao/AA4.pdf Acessado em 20 de novembro de 2007.

TRIGO, Luiz Gonzaga Godoi. Turismo Básico. São Paulo, SP: Editora SENAC, 2002.

LEAL, Wills. O Real e o Virtual no Turismo da Paraíba. João Pessoa, PB: Arpoardor Gráfica, 2001.

ATLAS IDH no Brasil 1991 - 2000.

http://www.pnud.org.br/atlas/

Álbum Virtual da cidade de Patos.

http://www.patosnet.net/album

Acessado em 11 de outubro de 2007.

Banco do Nordeste. Site do PRODETUR/ NE

http://www.bnb.gov.br/content/aplicacao/PRODETUR/Apresentacao

Acessado em 08 de outubro.

Banco do Nordeste. Relatório Final do Projeto 01. Dezembro/ 2005 
http://www.bnb.gov.br/content/aplicacao/prodetur/downloads/docs/docum_9_pcr_i.pdf Acessado em 10 de junho de 2007.

Banco do Nordeste. Relatório Final do Projeto 02. Dezembro/ 2005 http://www.bnb.gov.br/content/aplicacao/prodetur/downloads/docs/docum_10_pcr_ii.pdf Acessado em 10 de junho de 2007.

Banco do Nordeste. Relatório do TCU de Avaliação do PRODETUR/ NE. Parte 01, 2004.

http://www.bnb.gov.br/content/aplicacao/prodetur/downloads/docs/docum_4_rel_av_prod_i_tcu 1.pdf

Acessado em 10 de junho de 2007.

Banco do Nordeste. Relatório do TCU de Avaliação do PRODETUR/ NE. Parte 02, 2004.

http://www.bnb.gov.br/content/aplicacao/prodetur/downloads/docs/docum 5 rel av prod i tcu 2.pdf

Acessado em 10 de junho de 2007

Banco do Nordeste. Relatório do BID - Resultados e Lições Aprendidas.

http://www.bnb.gov.br/content/aplicacao/prodetur/downloads/docs/docum_2_bid_prod_i_result ados e licoes aprendidas.pdf

Acessado em 10 de junho de 2007.

Site do IBGE.

http://www.ibge.gov.br/

Acessado em 09 de setembro de 2007.

Muriçocas do Miramar.

http://www.muricocas.com.br

Acessado em 11 de outubro de 2007.

Onde Hospedar. Portal de Hotel e Pousadas no Brasil.

http://www.ondehospedar.com.br/

Acessado em 11 de outubro de 2007.

Governo do Estado da Paraíba. Setor de Geoprocessamento.

http://geo.aesa.pb.gov.br/

Acessado em 06 de maio de 2006.

Ministério do Turismo. Site do Programa Nacional de Regionalização do Turismo. http://www.turismo.gov.br/regionalizacao/

Acessado em 10 de setembro de 2007.

Paraíba.com. Site de informações do Estado da Paraíba. Cidades Virtuais.

http://www.paraiba.com.br

Acessado em 10 de outubro de 2007.

PAULO, Ricardo. CD turístico. Guia turístico da cidade de João Pessoa: 1000 imagens digitais do litoral paraibano. Editora Idéias \& Negócios, 2001. 
ANEXO 
ANEXO I - Especulação Imobiliária no Conde/ PB

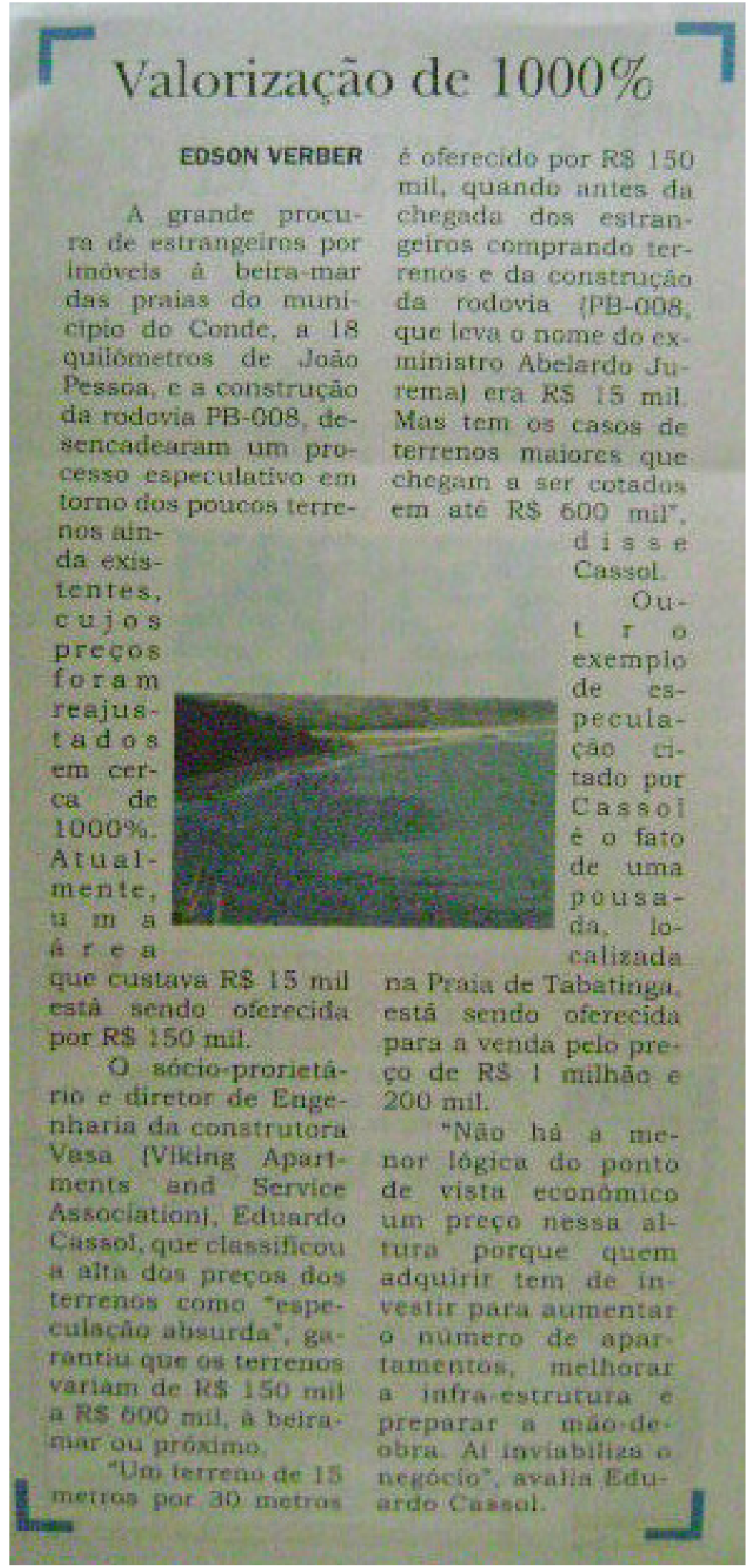

Fonte: Jornal Correio da Paraíba. Caderno de Economia, E2 Paraíba, Domingo, 10 de junho de 2007. 
ANEXO II - Conseqüência da Especulação Imobiliária no Conde/ PB

\section{ESPECULAÇÃO PODE AFASTAR INVESTIDORES}

\section{Empresário adverte que $80 \%$ dos terrenos no Conde estão à venda a preços impraticáveis pelo mercado}

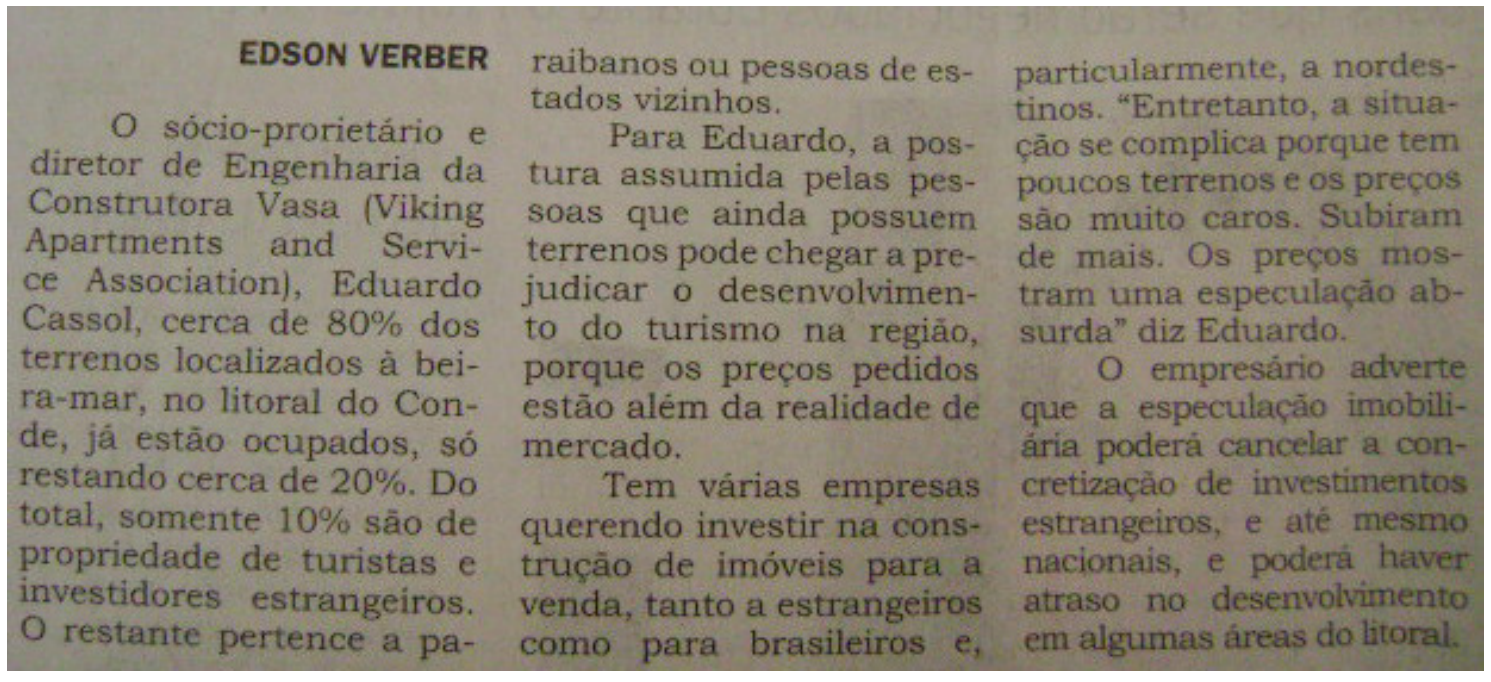

Fonte: Jornal Correio da Paraíba. Caderno de Economia, E2 Paraíba, Domingo, 10 de junho de 2007. 
ANEXO III: Opções de Roteiros Turísticos para o Interior da Paraíba

SEIS CIDADES DO BREJO CRIAM NOVO ROTEIRO

Turistas poderão curtir clima de inverno, paisagens de serra e uma extensa e intensa programação cultural

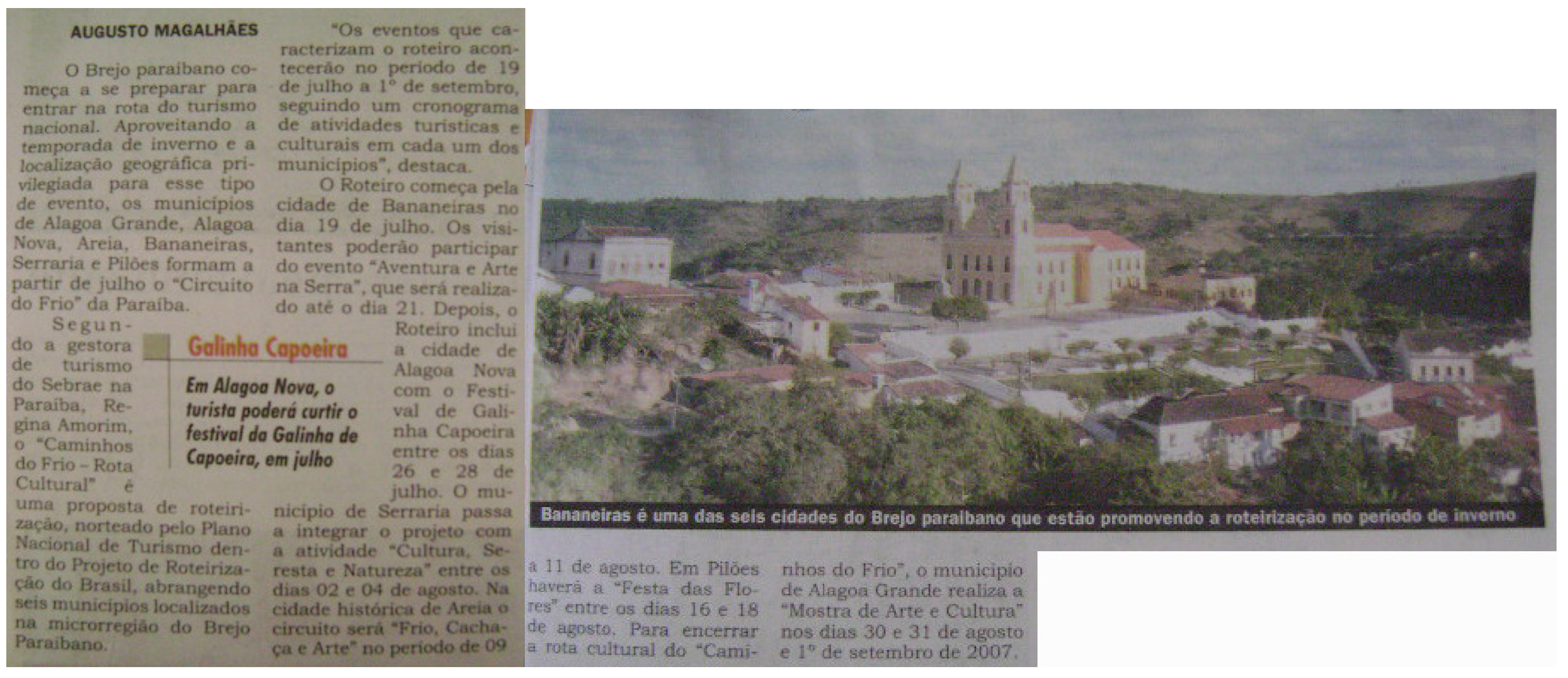

Fonte: Jornal Correio da Paraíba. Caderno de Turismo, L1 Paraíba, Domingo, 10 de junho de 2007. 


\section{DOS ENGENHOS AO CAMINHO DE PADRE IBIAPINA}

Turistas fazem passeio histórico pelo interior paraibano, conhecendo a "Civilização do Açúcar" também em PE e AL

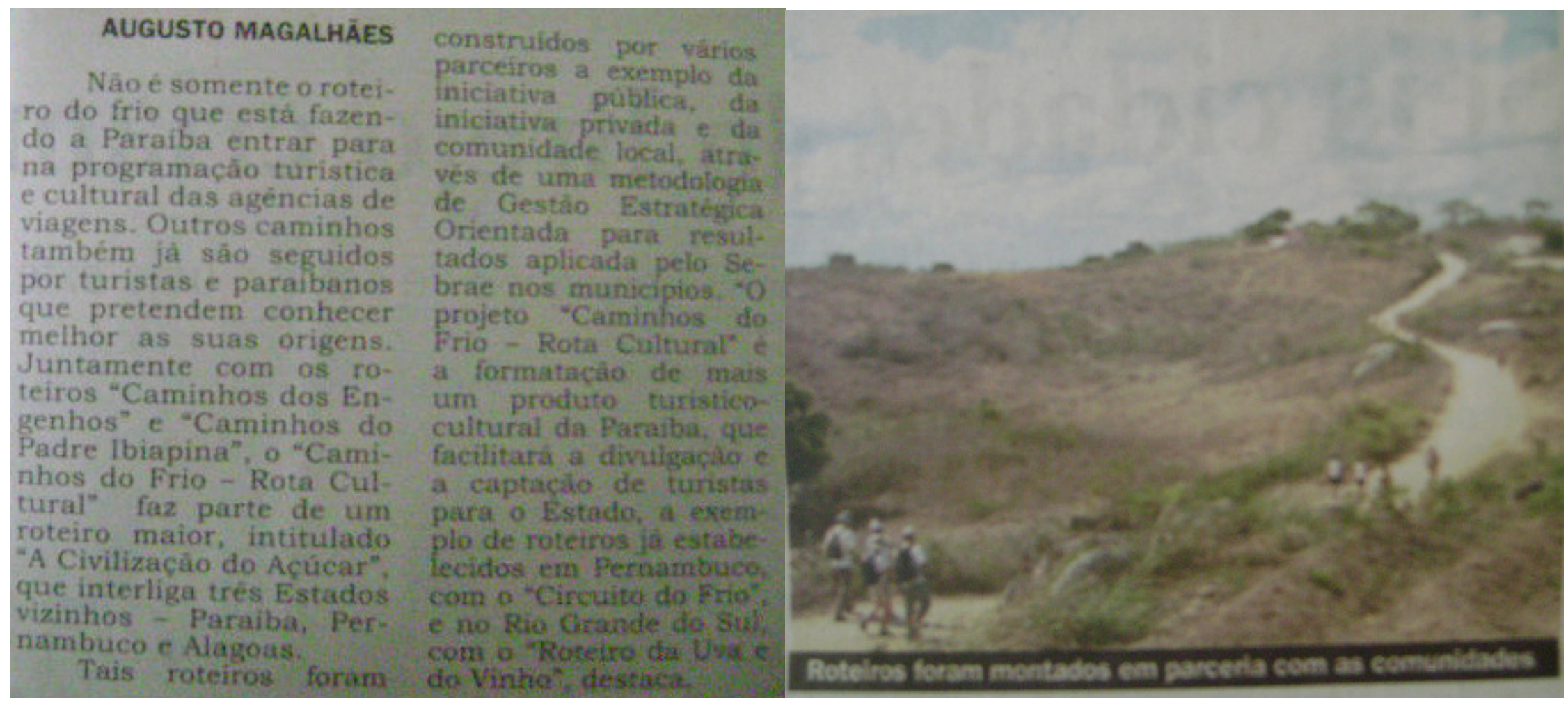

Fonte: Jornal Correio da Paraíba. Caderno de Turismo, L1 Paraíba, Domingo, 10 de junho de 2007. 
